ÁGUIDA ARRUdA BARBOSA

\title{
CONSTRUÇÃO DOS FUNDAMENTOS TEÓRICOS E PRÁTICOS DO CÓDIGO DE FAMÍLIA BRASILEIRO
}

\author{
TESE DE DOUTORADO \\ PROFESSORA ORIENTADORA \\ GISELDA MARIA FERNANDES NOVAES HIRONAKA
}

FACULDADE DE DIREITO UNIVERSIDADE DE SÃO PAULO SÃO PAULO 
ÁGUIDA ARRUDA BARBOSA

\section{CONSTRUÇÃO DOS FUNDAMENTOS TEÓRICOS E PRÁTICOS DO CÓDIGO DE FAMÍLIA BRASILEIRO}

Tese apresentada à Banca Examinadora da Faculdade de Direito da Universidade de São Paulo, como exigência parcial para a obtenção do título de Doutor em Direito Civil, sob a orientação da Professora Associada do Departamento de Direito Civil da Faculdade de Direito da Universidade de São Paulo Giselda Maria Fernandes Novaes Hironaka.

FACULDADE DE DIREITO

UNIVERSIDADE DE SÃO PAULO

SÃO PAULO

2007 
Banca Examinadora 
À minha família nuclear.

Luiz

o tu a me desvendar o $e u$ permitindo-me a plenitude da criação: Luiz André Luiz Eduardo 


\section{RESUMO}

A construção dos fundamentos teóricos e práticos para um Código de Família Brasileiro é orientada pelos paradigmas da doutrina pós-moderna, contendo os valores fundamentais que caracterizam o conhecimento jurídico para o terceiro milênio: pluralismo das fontes, comunicação, narrativa e retorno dos sentimentos. Trata-se da necessidade de narrar a alegria de viver do ser humano, reconhecido como um ser que pensa, sente, fala e escolhe.

A construção deste código não representa uma ruptura com o sistema anterior, mas, numa atitude pós-moderna, há uma justaposição do antigo e do novo, criativamente.

A família a ser reconhecida como pluralidade de sujeitos de direito é a nuclear, tendo por objetivo o livre desenvolvimento da personalidade e a busca da felicidade.

O conflito familiar é o desvio da função e dos papéis sistêmicos, com a conclusão de que o único conflito que existe é do casal conjugal, devendo ser objeto de estudo $a$ priori, quando o conflito se expressar como parental. A atuação do Judiciário nos conflitos familiares é narrada como método de retomada da via fundamentada na ética do cuidado, na dignidade da pessoa humana e na teoria da intuição.

As ferramentas eleitas para a aplicação prática do Código de Família Brasileiro são o juízo universal, a predominância do princípio da oralidade e a mediação familiar interdisciplinar.

O Direito Quântico fundamenta a prática da codificação, porque o biológico precede o Direito. A vida é o maior valor jurídico. O paradigma da física quântica funda-se na única certeza: a de que a única matéria que existe é o pensamento e o sentimento humano.

\section{UNITERMOS}

Pós-modernidade - Ética do Cuidado - Codificação - Intuição - Afetividade Conflito Humano - Mediação Familiar - Pluralismo das Fontes - Comunicação Narrativa - Retorno dos Sentimentos. 


\section{ABSTRACT}

The practical and theoretical fundaments construction for a Brazilian Family Code is oriented by the post-modern doctrine paradigms, containing the fundamental values that characterize the legal knowledge for the third millennium: pluralism of the sources, communication, narrative and the return of feelings. It is related to the necessity to narrate the joy of life in the human being, recognized as one being who thinks, feels, speaks and chooses.

The construction of this code does not mean a rupture with the previous system, however, for in a post-modern attitude, there is a juxtaposition of the old and the new in a creative way.

The family to be recognized as a plurality of law subjects is the nuclear one, which aims the personality free development and the search for happiness.

The family conflict is the deviation of the function and the systemic roles, and we can conclude that the only existing conflict is inherent to the married couple, and it has to be subject to prior study when the conflict expresses itself as a parental one. The role of the Judiciary in family conflicts is described as the retaking of the route, based on the ethics of care, on mankind dignity and on the intuition theory.

The chosen tools for the practical compliance with the Brazilian Family Code are universal judgment, predominance of the verbal principle, and family interdisciplinary mediation.

The Quantum Law justifies the codification practice because biological factors precede the science of Law. Life is the greatest legal value. The paradigm found in quantum physics is based on a single certainty: that the unique existing matter is the human thought and feelings.

\section{RELATED TERMINOLOGY}

Post-modern Times - Ethics of Care - Codification - Intuition - Affection Human Conflict -Family Mediation- Pluralism of the Sources - Communication Narrative - Return of Feelings. 


\section{RESUMÉ}

Le Code de la Famille brésilien est orienté vers les paradigmes de la postmodernité, dont les valeurs fondamentales marquent la connaissence juridique du troisième milénaire: pluralisme des sources, communication, narrative e retours des sentiments ou revival. Il s'agit de la nécessité de narrer la joie de vivre de l'être humain, reconnu comme celui qui pense, qui sent, qui parle et qui choisit.

La construction des fondements du code ne représente pas une rupture avec l'ancien système, mais, en face de la posmodernité il y a une coexistence juxtaposée, entre l'ancien et le nouveau, avec créativité.

La famille nucléaire y est considérée, comme un pluralisme des sujets de droit, dont le but est le développement de la personnalité vers le bonheur.

Le conflit familial est, donc, le détour de la fonction et des rôles du systhème familial. Il n'existe que le conflit conjugal, et en face du conflit parental il faut se pencher sur une étude a priori, pour y chercher les causes. L'action du Judiciaire en face du conflit familial est narrée comme une méthode, basée sur 1 éthique de la responsabilité, la dignité de la personne humaine et l'intuition.

Les outils choisis pour la pratique du Code de la Famille brésilien sont le l'universalité du juge, le principe de la communication orale et la médiation familiale interdisciplinaire.

Le Droit Quantique est le fondament de la pratique de la codification, parce que le biologique précède le Droit. La vie est la valeur juridique la plus importante. Le paradigme de la physique quantique est basée sur la sûreté: la seule matière qui existe est la pensée et le sentiment humain.

\section{MOTS-CLÉS}

Posmodernité - Éthique - Codification - Intuition - Conflit Humain - Médiation Familiale - Pluralisme des Sources - Communication - Narrative - Retours des Sentiments - Revival. 


\section{SUMÁRIO}

INTRODUÇÃO

\section{PARTE I \\ FUNDAMENTOS TEÓRICOS DA CONSTRUÇÃO DO CÓDIGO DE FAMÍLIA BRASIELIRO}

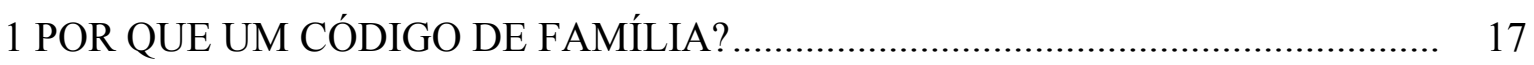

1.1 Tradição de Código Civil................................................................................. 17

1.2 França: busca de uma reorganização do Direito de Família .................................... 19

1.3 Panorama do Direito de Família no Brasil............................................................ 20

1.4 A Constitucionalização do Direito de Família.................................................... 23

2 O DIREITO DE FAMÍLIA PÓS-MODERNO......................................................... 27

$2.1 \mathrm{O}$ conceito de pós-modernidade ………......................................................... 27

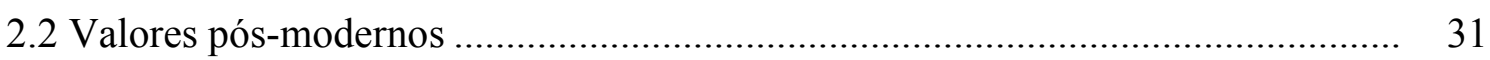

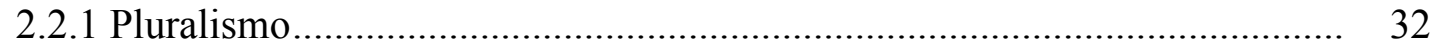

2.2.2 Comunicação …………………………………….......................... 32

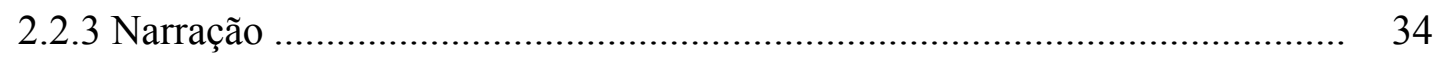

2.2.4 Retour des sentiments ou revival .......................................................... 36

3 A FAMÍLIA NA PÓS-MODERNIDADE_........................................................... 39

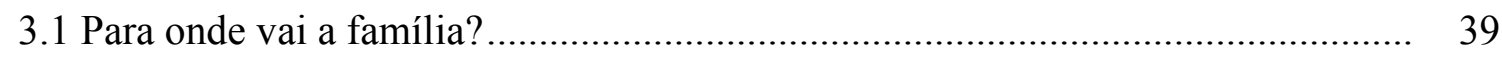

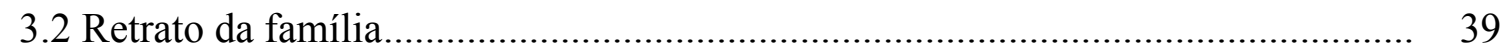

3.3 A família em ordem .............................................................................. 43

3.4 A família em desordem............................................................................. 47

3.4.1 Família monoparental e família reconstituída ou recomposta...................... 47

3.4.2 Declínio da soberania do pai e emancipação da subjetividade .................... 51

4 CONFLITO FAMILIAR E AFETO ................................................................... 55

4.1 Uma abordagem interdisciplinar.................................................................. 55

4.2 Uma abordagem interdisciplinar do conflito e do afeto pelo enfoque do direito.

5 FORMAÇÃO DO DIREITO DE FAMÍLIA BRASILEIRO ....................................... 65

5.1 A desigualdade entre os filhos ...................................................................... 66 
5.2 A desigualdade entre homem e mulher....................................................... 70

5.3 Da constitucionalização do Direito de Família ao Código Civil de 2002 ............. 74

6 CODIFICAÇÃO EM DIREITO DE FAMÍLIA …................................................ 79

6.1 A experiência francesa............................................................................... 79

6.2 Outras experiências estrangeiras............................................................... 83

6.3 Conceito de codificação ................................................................................ 85

6.4 Codificação na pós-modernidade.................................................................. 87

7 FUNDAMENTOS TEÓRICOS DO CÓDIGO DE FAMÍLIA BRASILEIRO............ 93

7.1 Critério de escolha dos fundamentos .............................................................. 93

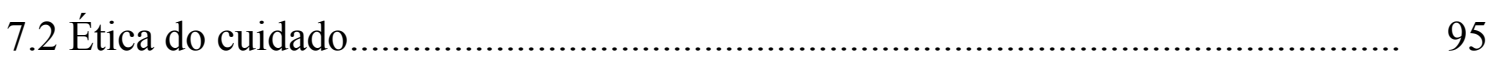

7.2.1 TU nasce antes do EU ...................................................................... 99

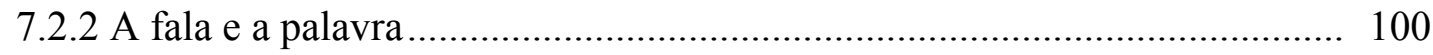

7.2.3 O primeiro EU ................................................................................ 102

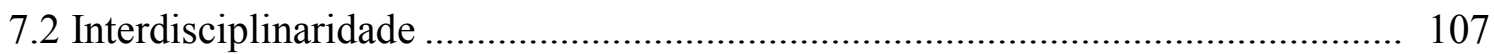

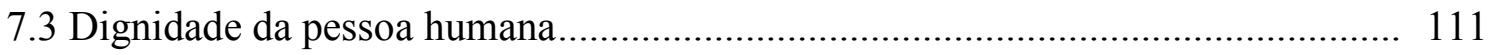

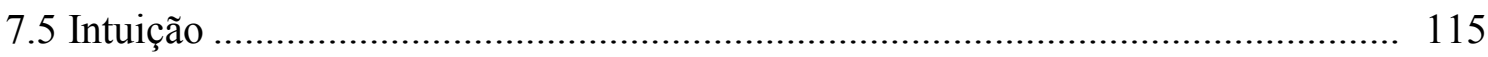

PARTE II

FUNDAMENTOS PRÁTICOS DA CONSTRUÇÃO

DO CÓDIGO CIVIL DE FAMÍLIA BRASILEIRO

8 A PRAXIS DO CÓDIGO DE FAMÍLIA BRASILEIRO .......................................... 118

8.1 Fundamentos práticos de construção do Código de Família brasileiro ................. 118

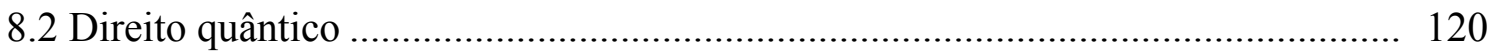

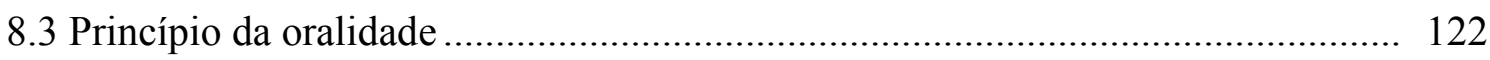

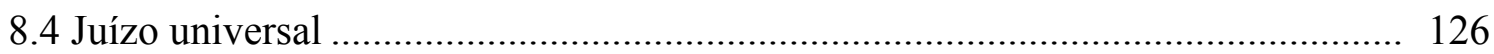

8.5 Mediação familiar interdisciplinar................................................................. 132

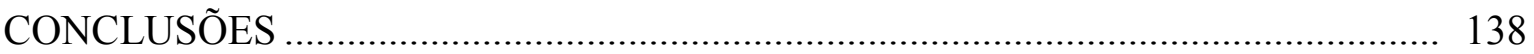

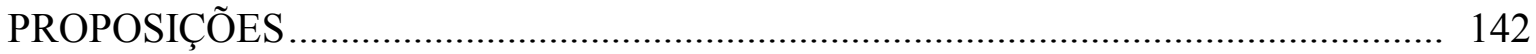

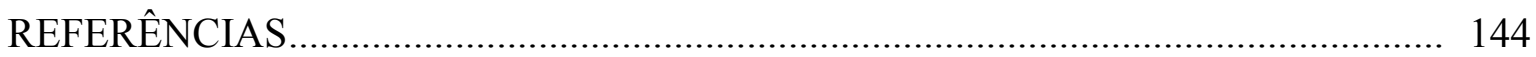




\section{INTRODUÇÃO}

O nascimento da idéia de um Código de Família decorre da intolerância e do inconformismo com as injustiças, perante a realidade da queda de qualidade da prestação jurisdicional, em especial, ao sujeito de direito de conflitos de família. A luta pelo aprimoramento do Direito de Família passou a nortear a busca de mecanismos capazes de promover a diminuição da distância, quase intransponível, entre o poder do Direito e sua eficácia em do jurisdicionado.

Aflora a necessidade de reconstrução do Direito de Família, bem como da formação dos profissionais do Direito, por meio da organização de um conhecimento jurídico fundamentado na interdisciplinaridade em mecanismos de prática deste conhecimento.

A construção de um Código de Família Brasileiro nasce de uma longa trajetória de estudos do Direito de Família aplicado à prática forense, desde a revolucionária década de 1960, até a segunda metade da primeira década do século XXI, esta com o registro que sinaliza a necessidade de atualização de suas práticas aos novos tempos, posto que intitulada, pela Unesco, a Década da Paz.

Há preocupações crescentes com o tema, a exemplo de ousadas propostas de inovação, como a implantação de juizados especiais de família, o acolhimento da mediação familiar como projeto dos Tribunais de Justiça de vários Estados, acompanhados de decisões revolucionárias e reveladoras de uma dessas atitudes inovadoras para lançar um olhar de otimismo para o futuro do Direito de Família. 
O objeto do presente estudo é a construção dos pilares de um conhecimento teórico e prático, por intermédio de um método - a interdisciplina ${ }^{1}$ - capaz de reconhecer a linguagem própria para desenhar o retrato da família do terceiro milênio, a ser expresso em um Código de Família Brasileiro.

A redação técnico-legislativa do Código de Família brasileiro não será o objeto deste estudo por exigir especialidade própria. Ademais, um código desta importância só poderá ter seu primeiro esboço oriundo de amplo debate entre juristas, legisladores e cidadãos.

Conforme será desenvolvido ao longo deste trabalho, a opção por um código autônomo funda-se, precipuamente, na pós-modernidade e num movimento de justaposição. Visar-se-á à conservação do clássico, porque narra a história dos institutos e para que o passado venha a se colocar ao lado de uma nova leitura, abrindo e ampliando o conhecimento numa nova perspectiva, numa produção de conhecimento transdisciplinar ${ }^{2}$.

Neste momento da historiografia do Direito de Família brasileiro, insta romper com a tradicional regulação das relações de família no Código Civil e apresentar os fundamentos de um Código de Família autônomo, com orientação própria e diversa da codificação geral de todas as relações de Direito Privado, como forma os diplomas de 1916 e o de 2002.

O esboço de um Código brasileiro fundamenta-se em paradigmas e princípios de doutrina pós-moderna, diferentemente dos demais códigos existentes, abrindo-se para o

1 ALMEIDA PRADO, Lídia. O juiz e a emoção. São Paulo: Milenium, 2003. p. 6: "A interdisciplinaridade amplia a potencialidade do conhecimento humano, pela articulação entre as disciplinas e o estabelecimento de um diálogo entre os mesmos, visando à construção de uma conduta epistemológica. A interdisciplinaridade é considerada como a mais recente tendência da teoria do conhecimento, decorrência obrigatória da modernidade, por se tratar de um saber oriundo da predisposição para um 'encontro' entre diferentes pontos de vista (diferentes consciências), o que pode levar, criativamente, à transformação da realidade."

2 Confira-se em: NICOLESCU, Basarab. O manifesto da transdisciplina. São Paulo: Coleção Trans, 2001. Com a trnasdisciplinaridade está-se ao mesmo tempo no campo disciplinar, entre as diversas disciplinas, e além delas, processa-se a compreensão por meio da unidade do conhecimento, formado pela inter, pluri, dis e transdisciplinaridade, o que ultrapassa o pensamento clássico. 
conhecimento amplo, com apoio na interdisciplinaridade ${ }^{3}$, agregando conhecimentos da Sociologia Jurídica, da Psicanálise, da Filosofia, enfim, um conhecimento que vai além da soma de outras disciplinas, sem o qual a prestação jurisdicional, no âmbito das relações familiares, revelar-se-á inadequada ou insuficiente.

Exemplo marcante da defeituosa prestação jurisdicional é a freqüente multiplicidade de ações geradas por um conflito "sentenciado". Percebe-se que, quando é incompleta a função do Estado, resta um vazio aos sujeitos de direito, que voltam ao Judiciário com novas demandas, às vezes, travestidas de outra causa de pedir. O que ocorre é a falta de conhecimento a respeito da indivisibilidade do conflito familiar, o que será desenvolvido em capítulo próprio.

Quando o direito assegurado em sentença é inexeqüível, a exemplo do direito de visitar os filhos, e quando não há reconhecimento internalizado pelo genitor guardião, na falta de outros mecanismos jurídicos, outra ação que lhe assegure esta inclusão familiar, só resta a violência da busca e apreensão da criança.

No entanto, esta medida não tem eficácia para reconstrução do papel parental, porquanto seja fundamentada na violência, legitimada para coibir outra violência, criando um círculo vicioso. É comum, no entanto, que o titular do direito de visitas não se valha da busca e apreensão, por aversão a ela, e, inconscientemente, apresente o conflito ao Judiciário em outra roupagem: revisional de alimentos para reduzir o encargo não reconhecido na função parental, ou, deixando de pagar os alimentos, submete-se às intermináveis execuções com penhora ou pedido de prisão.

3 JAPIASSU, Hilton. Interdisciplinaridade e patologia do saber. Rio de Janeiro: Imago, 1976. p. 72 , "interdisciplinaridade corresponde a uma evolução dos tempos atuais, resultante de um caminho irreversível, vindo preencher os vazios deixados pelo saber proveniente das áreas de especialidade do conhecimento, constitui importante instrumento de reorganização do meio científico, a partir da construção de um saber que toma por empréstimo os saberes de outras disciplinas, integrando-os num conhecimento de um nível hierarquicamente superior, desencadeando uma transformação institucional mais adequada ao bem da sociedade e do homem". 
A falta de conhecimento desta rede subjacente, originária das demandas judiciais, acarreta prejuízos materiais e morais incalculáveis à máquina do Estado, ao jurisdicionado e à própria cidadania, vista neste trabalho como oportunidade de participação e inclusão na rede social. Há consciência da crise do Judiciário, mas as iniciativas que visam à contenção das demandas são distantes da causa.

Os fundamentos do Código de Família brasileiro inserem e alicerçam a natureza reparatória e preventiva do Direito de Família, função preponderante na doutrina pósmoderna. Seguramente, não se pode atribuir ao Judiciário e aos profissionais do Direito uma atuação cuja natureza seja de psicoterapia, especialidade da área de saúde mental, que exige formação profissional regulamentada para sua atuação. Pode-se reconhecer, no entanto, que a conduta adequada de acolhimento do conflito familiar tem efeitos terapêuticos e pode devolver ao jurisdicionado a capacidade de entendimento de suas transformações, pela experiência das relações de afeto.

É preciso reconhecer, ademais, que a necessidade de construção de um Código de Família advém da moderna tendência de pulverização do Direito em direitos subjetivos, título de um capítulo contido na obra Droit et Passion du Droit sous la V. ${ }^{\text {ème }}$ République ${ }^{4}$, de Jean Carbonnier. Para este autor no terceiro milênio não é mais possível permanecer na limitação de formulações doutrinárias de outrora, pois, nos novos tempos, há uma perspectiva oposta: parte-se dos direitos subjetivos, para construir o direito objetivo, que se constituirá sob o paradigma de rede dos primeiros. A tendência à subjetivação dos direitos manifesta-se, transformando o direito objetivo em avesso dos direitos subjetivos.

O primeiro passo para a mudança da maneira de pensar o caminho de acesso à justiça, especialmente em relação ao Direito de Família, foi acolher o princípio da dignidade da pessoa humana, previsto no artigo 1º, III, da Constituição Federal de 1988, que o alça como fundamento do Estado Democrático de Direito. Logo, qualquer exegese deve ser feita sob o pilar deste princípio.

4 CARBONNIER, Jean. Droit et passion du droit sous la v. ${ }^{\text {eme }}$ République. França: Flamarion, 1996. p. 121 
Impõe-se uma sistematização que possa resgatar as tradições do Direito de Família brasileiro, integrando as conquistas jurisprudenciais, doutrinárias, legislativas, de usos e costumes, enfim, os novos paradigmas que foram se formando ao longo das últimas décadas, para propor um Código capaz de acolher a família e reconhecê-la como lugar para desenvolvimento da personalidade.

Para a formação desta codificação especializada e independente, é preciso compreender a função da família. Vale lembrar a expressão de Marie-Thérèse MeuldersKlein ${ }^{5}$, que assim a define: família é o principal lugar da felicidade.

Com os avanços da bioética e da compreensão da família por meio da interdisciplinaridade, resgata-se o princípio da verdade nas relações jurídicas da família, assim compreendido por Guilherme de Oliveira:

\begin{abstract}
“(...) pode-se dizer que atualmente o Direito de Família tende a conformar-se sob a inspiração de um princípio da verdade: as prescrições jurídicas tendem a reconhecer as aspirações, as necessidades e a situação real, biológica e afectiva dos membros da comunidade familiar. Não se trata hoje, pois, de identificar o Direito da Filiação com a Biologia, mas, sim, de reencontrar o ponto de equilíbrio". 6
\end{abstract}

Portanto, o princípio da verdade vem em favor de uma integração do Direito de Família, promovendo o equilíbrio entre a verdade biológica e a verdade psíquica, para acolher, definitivamente, o valor jurídico da maternidade/paternidade socioafetiva.

Ademais, é preciso reconhecer a constitucionalização do Direito de Família, que acarreta uma revolução sistêmica, com o princípio da igualdade entre homem e mulher e

MEULDERS-KLEIN, Marie-Thérèse. Liber amicorum, Bruxelas: Ruylant, 1998. p. 175.

6 OLIVEIRA, Guilherme. Temas de direito de família. 2. ed. Coimbra: Coimbra Editora, 1999. p. 5-16. 
entre os filhos. Como havia discrepância entre as normas constitucionais e as normas do Código Civil de 1916, prevaleciam as da Constituição Federal, sobrepondo-se à Lei Civil.

No Código Civil de 2002, Miguel Reale imprimiu a orientação filosófica que leva a um pluralismo de fontes, à plena principialização do Direito de Família, cuja interpretação pressupõe, obrigatoriamente, a visão de um Direito de Família constitucionalizado.

A introdução à temática da construção do Código de Família brasileiro anuncia, enfim, um movimento de abertura, de pluralidade, de possibilidades e criatividade, cujos fundamentos estão sobejamente desenvolvidos por Cláudia Lima Marques ${ }^{7}$ ao descrever o estado da arte do Direito de Família nesta transição de século e milênio:

"Dos ramos do Direito Civil era ele um dos mais unidos à prática e ao mesmo tempo um dos menos estudados. Da concentração de estudos romanos, canônicos e do século XIX, a família no século XX parecia não mais representar um desafio científico para o Direito. O motivo era simples, sua prática era agora considerada humana ou fácil demais para os 'juristas'. Hoje o Direito de Família renasce, despertando para uma nova atenção científica.”

7 MARQUES, Claudia Lima. Visões sobre o teste de paternidade através do exame do DNA em direito brasileiro: direito pós-moderno à descoberta da origem. In: LEITE, Eduardo Oliveira (Coord.). Grandes temas da atualidade de DNA como meio de prova de filiação. 2. ed. São Paulo: Forense, 2002. 
PARTE I

FUNDAMENTOS TEÓRICOS DA CONSTRUÇÃO DO CÓDIGO DE FAMÍLIA BRASIELIRO

"Há um tempo em que é preciso abandonar as roupas usadas, que já têm a forma do nosso corpo, e esquecer os nossos caminhos, que nos levam sempre aos mesmos lugares.

É tempo da travessia: e, se não ousarmos fazê-la, teremos ficado, para sempre, à margem de nós mesmos."

Fernando Pessoa 
POR QUE UM CÓDIGO DE FAMÍLIA?

\subsection{TRADIÇÃO DE CÓDIGO CIVIL}

Uma primeira indagação a ser feita em relação ao tema diz respeito à real necessidade de um Código de Família. Isso porque o Livro IV do Código Civil brasileiro de 2002 regula amplamente a matéria, seguindo a tradição da sistemática do Código Civil de 1916, que dedicava o Livro II ao Direito de Família. A resposta a tal indagação merece aprofundamento diante da concepção atual do Direito de Família.

A respeito do tema, cabe um registro para a particular situação existente na França.

No bicentenário do Código de Napoleão, firmou-se uma forte manifestação de apego à tradição de manter ali inserido o Direito de Família, sem se aventar a possibilidade ou à tendência de destacar as relações de família para uma codificação especializada. No entanto, como se verá oportunamente, a França tem um Código de Família que não é reconhecido pela comunidade jurídica, é letra morta da lei. Nunca houve a idéia de substituição da regulação das relações de família, previstas no Código Civil francês, pelo Código de Família, pois, tecnicamente, este não corresponde a um código - é mera consolidação de leis que regulam as diversas matérias sobre família.

O Código Civil francês não tem um livro dedicado às relações jurídicas de Direito de Família, a exemplo das codificações brasileiras. Nele, o Direito de Família está regulado 
no Livro Primeiro ${ }^{8}$, sob o título "Das Pessoas" e, em relação aos efeitos patrimoniais do casamento, o regime de bens aparece no Livro Terceiro", com o título "Diferentes Maneiras de Adquirir a Propriedade", tendo como Título 5, artigos 1.370 a 1.581, o subtítulo "Do Contrato de Casamento e os Regimes Matrimoniais".

Jean Carbonnier ${ }^{10}$ acentua, criticamente, o fato de não haver, no Código Civil francês, parte distinta dedicada ao Direito de Família, embora este ramo do Direito Privado mereça tanta confiança do cidadão.

No entanto, é preciso compreender o critério adotado pelo legislador, pois trata-se de uma questão axiológica. É que o Direito Civil francês tem como valor maior os direitos do homem, portanto, na escala axiológica, a pessoa ocupa o primeiro lugar. Segundo Carbonnier ${ }^{11}$, o artigo 16 do código em exame expressa bem essa idéia: "A lei assegura a primazia da pessoa, proíbe todo atentado à dignidade desta e garante o respeito ao ser humano desde o começo da vida". Realmente, o bem maior a merecer proteção da lei é a pessoa. Sendo a família uma relação entre, no mínimo, duas pessoas, deve estar, obrigatoriamente, em segundo lugar, na escala axiológica, pois, afinal, há pessoas que não têm família.

Mesmo com toda a tradição do Código Civil francês abarcando o Direito de Família, evidencia-se a preocupação dos juristas em buscar uma organização dos artigos do Livro Primeiro, que trata da matéria atinente às pessoas e à família, dando-lhe uma

8 CODE CIVIL FRANÇAIS. LIVRE PREMIER: Des personnes Titre 01 - Des Droits Civils (7 à 16-12) Titre $1 \mathrm{~b}$ - De la Nationalité Française (17 à 33-2); Titre 02 - Des Actes de l'Etat Civil (34 à 101); Titre 03 - Du Domicile (102 à 111); Titre 04 - Des Absents (112 à 143); Titre 05 - Du Mariage (144 à 228); Titre 06 - Du Divorce (229 à 310); Titre 07 - De la filiation (311 à 342-8); Titre 08 - De la filiation adoptive (343 à 370-2); Titre 09 - De l'autorité parentale (371 à 387); Titre 10 - De la minorité, de la tutelle et de l'émancipation (388 à 487); Titre 11 - De la majorité et des majeurs qui sont protégés par la loi (488 à 514)

9 CODE CIVIL FRANÇAIS. LIVRE TROISIĖME. Des différentes manières dont on acquiert la propriété (711 à 2283); Titre 05 - Du contrat de mariage et des régimes matrimoniaux (1387 à 1581).

10 CARBONNIER, Jean. Droit civil. 18. ed. Vendôme: PUF, 1997. t. 2: La famille, p. 13-14.

11 CODE CIVIL FRANÇAIS. Op. cit., p. 14. "Maintenant, le droit civil ayant décidément épousé les Droits e l'homme, c'est la valeur de la personne qui prend le dessus. L'apothéose est à l'a 16, véritable proclamation de philosophie personnaliste . Article 16:- La loi assure la primauté de la personne, interdit toute atteinte à la dignité de celle-ci et garantit le respect de l'être humain dès le commencement de sa vie". HAUSER, Jean; CASEY, Jérôme. Code des personnes et de la famille - Textes - Commentaires Jurisprudence-Conseils pratiques. Paris: Litec, 2003. 
amplitude além da codificação. Em suma, a doutrina sinaliza que o Código Civil francês já não se mostra apto a nortear satisfatoriamente as questões de Direito de Família.

\subsection{FRANÇA: BUSCA DE UMA REORGANIZAÇÃO DO DIREITO DE FAMÍLIA}

Corroborando a sinalização da doutrina, merece registro a recente obra francesa ${ }^{12}$ Code des Personnes et de la Famille - Textes - Commentaires - Jurisprudence - Conseils Pratiques, editada em novembro de 2003, que apresenta uma organização peculiar acerca da matéria. O título do livro indica, claramente, a pretensão de ser um Código das Pessoas e da Família, mas, tecnicamente, trata-se apenas de uma parte do amplo Código Civil francês.

A segunda edição desta obra em referência traz a rubrica 2004/2005, o que transmite a idéia de anuário, indicando uma atualização da legislação e, com certeza, de tendências da jurisprudência. Enfim, há uma conotação de código anotado. Não há, porém, qualquer referência ao Código da Família e da Ação Social, existente na França desde 1939, mas há conteúdo e referências ao "Direito não Civil da Família", isto é, todas as relações jurídicas que envolvem a família, a exemplo das relações fiscais, atrativas aos franceses, em virtude do incentivo legal creditado a estas relações. É mais econômico manter-se em família, porque os solteiros e descasados pagam mais impostos.

Conforme consta da própria apresentação da publicação, nota-se que:

“o conteúdo original, próximo de enciclopédia, junta em uma só obra as informações relativas ao direito das pessoas e da família, com textos que têm o objetivo de servir de fonte, com comentários

12 HAUSER, Jean; CASEY, Jérôme. Code des personnes et de la famille - Textes - Commentaires jurisprudence-Conseils pratiques. Paris: Litec, 2003. 
doutrinários, jurisprudência e conselhos práticos, além das referências bibliográficas, que permitem o aprofundamento das matérias de maior interesse." ${ }^{13}$

Enfim, para o presente estudo, esta análise norteia os passos para a demonstração da necessidade de construção de um Código de Família. No entanto, a construção deste deverá estar distante da experiência francesa, pois, embora sinalize a recente elaboração de uma nova abordagem para aprimoramento do Direito de Família naquele país, esta recente oganização não tem um bom relacionamento com o Código de Família existente, o que será objeto de estudo, oportunamente.

Ademais, conforme demonstrado, a última experiência de busca de reorganização do Direito de Família francês e da codificação não indica a pretensão de uma orientação interdisciplinar, como tem sido a marca contemporânea. No entanto, a contribuição desta análise é o reconhecimento de que o Direito de Família deve ser tratado como direitos da personalidade.

Constata-se, enfim, que o Direito de Família desenvolveu-se de tal modo, ganhando amplitude tão expressiva, que não cabe mais no âmbito do Direito Civil, prescindindo de codificações próprias, regidas por paradigmas particulares.

\subsection{PANORAMA DO DIREITO DE FAMÍLIA NO BRASIL}

O mesmo fenômeno de falta de abordagem interdisciplinar, de acordo com os paradigmas pós-modernos ocorre no ordenamento jurídico pátrio, o que evidencia a carência de um Código de Família brasileiro.

13 O prefácio é de autoria dos organizadores da obra, contendo explicações sobre os propósitos da obra, como instrumento de trabalho prático para professores, alunos, estudantes etc. p. IX. 
Esta evidência repousa na prática de condutas dos operadores do Direito, que desvirtuam o sentido das normas que visam à proteção do sujeito de direito, pois não convergem à legítima prestação jurisdicional pretendida pelas partes, devido ao distanciamento que se estabelece em relação à natureza do conflito. A causa deste fenômeno centra-se na falta de qualificação e especialização do Direito de Família, seja como prática jurídica, seja como teoria, reconhecendo que este ramo do Direito tem características próprias e peculiares que estão além do Direito Civil.

Os fundamentos do Código de Família brasileiro emergem de uma visão ampla do conflito, este visto como natural a qualquer humano, tratando-se de manifestação de vida. Portanto, o conflito não pode ser visto como fato anti-social, rejeitado pela comunidade, impondo que seja resolvido com renúncias mútuas, convergentes à conciliação, sob o argumento que se tornou um adágio popular: "é melhor um mau acordo que uma boa demanda".

É muito comum colher depoimentos de cidadãos que já obtiveram a prestação jurisdicional a uma demanda de Direito de Família, mas revelam que essa não satisfez a legítima demanda que buscaram no Judiciário. Sentem-se, freqüentemente, agredidos pela ausência de oportunidade do exercício da palavra, não servindo como encaminhamento capaz de indicar a retomada da vida em suas próprias mãos. Esses cidadãos vão em busca do Poder do Estado, porque estão impotentes, mas saem sem a devida potência de cidadania que buscaram no Judiciário, porque a distribuição de justiça não levou em conta o ser humano em sofrimento.

O Direito de Família e o Judiciário não têm um corpo de normas e mecanismos jurídicos de acesso à justiça adequados aos conflitos decorrentes das relações de afeto, não estão aparelhados para reconhecer que o jurisdicionado está doente, buscando a proteção do Estado para reconduzi-lo à integridade moral e afetiva, porque o trata de acordo com outros princípios e paradigmas, próprios para as relações de Direito Privado, de um modo geral, que não servem mais para este peculiar ramo do Direito. 
Se o Judiciário estivesse apto a promover condições de elaboração de um projeto de futuro aos jurisdicionados, capacitando-os a exercer os novos papéis nas relações familiares após a ruptura do casamento ou da união estável, poderia evitar muitos desgastes no pós-ruptura. Isso porque alguns cidadãos acabam retornando ao próprio Judiciário, com novos conflitos familiares. Neste sistema já superado de distribuição de justiça, a função é reduzida a responder à prestação jurisdicional pretendida, sentenciando, assim, regulamentação de visitas, fixando pensão alimentícia etc. A jurisdição esgota-se com a decisão e não acompanha a organização dos novos papéis familiares; portanto, ela foi ineficiente.

Em decorrência, o Direito de Família deve ser reconhecido como um ramo autônomo do Direito Privado, necessitando de um Código de Família brasileiro capaz de acolher este conhecimento, espelhando a cultura brasileira, com seus matizes, sob influência de seu clima, das religiões que se comunicam e convivem, com seus valores e sua criatividade.

Ademais, com a revolução do Direito de Família, ocorrida durante a segunda metade do século XX, mas que avança a passos largos nesta primeira década do século XXI, esse ramo do Direito sofre profundas mudanças paradigmáticas, cujas leis não as acompanham, e urge a necessidade de um Código de Família aberto, capaz de absorvê-las.

Em verdade, o atual Direito de Família afastou-se da doutrina positivista, pois, pelos novos paradigmas, não cabem mais previsões punitivas, a exemplo do princípio da culpa, para ser substituída pelo princípio da responsabilidade, humanizando, assim, os conflitos familiares.

A necessidade de adaptação do Direito de Família para se tornar exeqüível, em seu papel de satisfazer a demanda do jurisdicionado, com os instrumentos jurídicos disponíveis para este momento histórico, é norteada para o futuro e não mais para o passado, como está no Código Civil. A mente do jurista já se abriu para o novo modelo de 
família, e, como disse Einstein, o cientista de todos os tempos, esta mente jamais voltará ao seu tamanho original.

\subsection{A CONSTITUCIONALIZAÇÃO DO DIREITO DE FAMÍLIA}

A constitucionalização do Direito de Família sinaliza para a necessidade de um sistema maior para acolher o Direito de Família, justificando, assim, a criação de um Código de Família brasileiro.

Não é mais possível apequenar o Direito de Família, paradoxalmente limitado ao amplo sistema do Código Civil, pois, os novos paradigmas orientadores desse direito estão em acolher a diversidade, reconhecendo que, em lugar das verdades absolutas, a verdade real está no reconhecimento das possibilidades, do plural, no diálogo das fontes.

Para Erik Jayme ${ }^{14}$, o necessário “diálogo das fontes” (dialogue des sources), permite a aplicação simultânea, coerente e coordenada das plúrimas fontes legislativas convergentes. "Diálogo" porque há influências recíprocas e aplicação das duas normas ao mesmo tempo e ao mesmo caso, seja complementamente, seja subsidiariamente, seja permitindo a opção voluntária das partes sobre a fonte prevalente, "especialmente em matéria de convenções internacionais e leis-modelos", ou mesmo permitindo uma opção por uma das leis em conflito abstrato. Uma solução flexível e aberta, de interpenetração, ou mesmo a solução mais favorável ao mais fraco da relação (tratamento diferente dos diferentes).

Até a Constituição Federal de 1988, a Lei Maior do Direito de Família era o Código Civil de 1916. É preciso reconhecer a carga revolucionária trazida pela Carta Magna de 1988 ao Direito e Família, que muda o sistema de exclusões, até então vigente -

14 JAIME, Erik, apud MARQUES, Claudia Lima. Visões sobre o teste de paternidade através do exame do DNA em direito brasileiro: direito pós-moderno à descoberta da origem. In: LEITE, Eduardo de Oliveira (Coord.). Grandes temas da atualidade de DNA como meio de prova de filiação. 2. ed. São Paulo: Forense, 2002. p. 36 
filiação apenas legítima, família apenas legitimada pelo casamento - passando ao sistema das inclusões - igualdade entre todos os filhos, pluralidade de formas de constituição da família, princípio da igualdade entre homem e mulher. Nas palavras de Fachin:

\begin{abstract}
"emergindo questões sobre o sistema clássico que já consistem, elas mesmas, objeto de novas interrogações. Liame genético: verdade única? Paternidade afetiva? Temas e problemas que se enfileiram ao lado da maternidade por substituição. Menos que naufrágio, essa 'dobra' do sistema clássico, uma virada do clássico para o contemporâneo, põe em cena também seus limites, e expõe, de outra parte, suas possibilidades. ${ }^{, 15}$
\end{abstract}

Com a mudança de dimensão do Direito de Família impôs-se caminhar entre duas epistemologias ${ }^{16}$, posto que foram ampliados os contornos deste conhecimento jurídico: a racional de Descartes e a compreensiva de Espinoza. Esta dimensão do Direito de Família exige a incorporação da interdisciplinaridade, permitindo o diálogo entre as epistemologias: ${ }^{17}$ "A questão da Palavra, como ela se articula, o valor da palavra pronunciada, o cuidado no Dizer, a necessidade de Ouvir".

Com a amplitude alcançada pelo Direito de Família, o jurista está obrigado a recorrer ao conhecimento de outras ciências, sendo as contribuições mais fundamentais advindas da Filosofia, Psicanálise, Sociologia e Antropologia. Esta ampliação do conhecimento tem marco inicial na década de 1960, quando nasce a exploração da subjetividade, mas, na década de 1990, como explica Fazenda:

"estuda-se o subjetivo sem encarná-lo ou vivê-lo, melhor dizendo, reflete-se sobre o subjetivo, mas faltam instrumentos que permitam a personificação do pensamento, a potencialização do pensamento

15 FACHIN, Edson Luiz. Direito de família. Elementos críticos à luz do novo Código Civil brasileiro. In: LIRA, Ricardo Pereira (Coord.). 2. ed. Rio de Janeiro: Renovar, 2003. p. 50.

16 FAZENDA, Ivani. Interdisciplinaridade: qual o sentido? São Paulo: Paulus, 2003. p. 5.

17 FAZENDA, Ivani. Interdisciplinaridade, p. 7. 
tornado ato (...). A Psicologia, banida da educação nas décadas anteriores, engatinha sua volta. A releitura de Vigotsky, Freud e Jung conduz a uma antropologia do sujeito. Há uma necessidade de interiorização que propicie a exteriorização."18

Já em 1969, o civilista Jean Carbonnier ${ }^{19}$, em sua obra Flexible droit, foi pioneiro dentre os juristas interdisciplinares ao ampliar o conhecimento do Direito Civil com a contribuição da Sociologia Jurídica, para a compreensão dos institutos jurídicos. $\mathrm{Na}$ área do Direito de Família, alargou significativamente a compreensão da formação e da ruptura do casal conjugal.

Como bem enfatiza Claudia Lima Marques ao analisar o estado da arte do Direito de Família, tanto no Brasil como nos países europeus, a exemplo da Alemanha:

“O Direito de Família vive hoje um renascimento científico. Dos ramos do Direito Civil era um dos mais unidos à prática e, ao mesmo tempo, um dos menos estudados. Da concentração de estudos romanos, canônicos e do século XIX, a família no século XX parecia não mais representar um desafio científico para o Direito. O motivo era simples, sua prática era agora considerada humana ou fácil demais para os "juristas". Hoje, sua prática continua muito unida aos sentimentos, à vida, e ao complexo comportamento privado social do homem de nosso tempo, mas os costumes mudaram, novos sujeitos de direito aparecem juridicamente, a tecnologia mudou, a família internacionalizou-se, e esta mistura passou a chamar a atenção dos juristas nova e profundamente. $\mathrm{O}$ que era antes um minus científico (sua proximidade sentimental e cultural com as diferentes pessoas),

18 FAZENDA, Ivani. Interdisciplinaridade, p. 8.

19 CARBONNIER, Jean. Flexible droit. 8. ed. Paris: LDDJ, 1995. p. 217-225 
desperta hoje uma nova atenção científica: um direito de nossos tempos (pós-moderno)." 20

O Código de Família Brasileiro tem, portanto, fundamento na doutrina pósmoderna, com a construção de um sistema de regras orientado por um movimento de pluralidade e de possibilidades, por meio da descrição positiva de comportamentos.

Dessa forma, torna-se indissociável a noção atual do Direito de Família com o fenômeno da pós-modernidade, motivo pelo qual no capítulo seguinte será feito um aprofundamento de seu conceito.

20 MARQUES, Claudia Lima. Visões sobre o teste de paternidade através do exame do DNA em direito brasileiro, p. 29-30. 


\section{O DIREITO DE FAMÍLIA PÓS-MODERNO}

\subsection{O CONCEITO DE PÓS-MODERNIDADE}

A compreensão do Direito de Família pós-moderno exige uma incursão no conceito de pós-modernidade, que fundamenta a construção do Código de Família brasileiro.

A expressão sócio-filosófica "pós-moderno" deve ser apreendida como uma doutrina, que não comporta, portanto, uma definição limitativa a partir de um marco no tempo. Para o jurista interdisciplinar Jean Carbonnier,

\footnotetext{
“a irrupção desta doutrina deu-se no Século XX, nas décadas de 70 e 80, porém, o início desse profundo movimento de reação, não menos que de progresso, é a Declaração dos Direitos do Homem em 1789, marco de ruptura libertária que permitiu o florescimento da pós-modernidade dois séculos mais tarde". ${ }^{21}$
}

O termo pós-modernidade surgiu nos Estados Unidos, no final da década de 1960, e foi acolhido na Europa com essa mesma designação. O assunto passou a ser estudado pela Filosofia e pela História, tendo em Jean-François Lyotard, Michel Foucault, Jean Baudrillard e Jacques Derrida seus principais estudiosos, preocupados com o desenvolvimento dos fundamentos deste fenômeno. Caracterizada por não gerar consensos

21 CARBONNIER, Jean. Sociologie juridique. Vendôme, França: PUF, 1994. p. 145-146. 
(não há, por exemplo, concordância sobre o seu início nem sobre sua definição), a pósmodernidade despertou opositores.

Dentre os contestadores da pós-modernidade, Ernest André Gellner conceitua-a como um movimento contemporâneo que está na moda. $\mathrm{O}$ autor insiste, ainda, que, na verdade, a claridade não se encontra entre os seus principais atributos, e que o pósmodernismo não apenas falha em praticar a claridade, mas, em algumas ocasiões, até a repudia abertamente. ${ }^{22}$.

Dentre os cultores da pós-modernidade, destaca-se o filósofo francês JeanFrançois Lyotard, um dos mais importantes pensadores na discussão da identificação de uma doutrina pós-moderna. Jean-François Lyotard enaltece sua importância como fenômeno apto a romper com as antigas verdades absolutas, como marxismo e liberalismo, todas elas legítimas representantes da modernidade ${ }^{23}$. O autor sugere um marco inicial para o fenômeno que denomina "sociedade pós-industrial" e "cultura pós-moderna":

"Esta passagem começou desde pelo menos o final dos anos 50, marcando para a Europa o fim de sua reconstrução. Foi mais ou menos rápida conforme os países e, nos países, conforme os setores de atividade: donde uma discronia geral, que não torna fácil o quadro de conjunto." 24

Desta referência temporal, depreende-se que a pós-modernidade é uma resposta revolucionária aos valores que deram causa às duas grandes guerras mundiais, na primeira metade do século XX, e tiveram a expressão máxima de intolerância no nazismo, com a política de racismo. Enfim, a Europa teve que promover sua reconstrução física e de valores.

22 GELLNER, Ernest André. Pós-modernismo, razão e religião. Lisboa: Piaget, 1994.

23 LYOTARD, Jean-François. A condição pós-moderna. 5. ed. São Paulo: José Olímpio, 1988.

24 LYOTARD, Jean-François. A condição pós-moderna, p. 19. 
Seguramente, o fim da modernidade ocorre na década de 50, no período pósguerra, e diante de um vazio doutrinário. Leonardo Boff bem elucida o pensamento reinante à época:

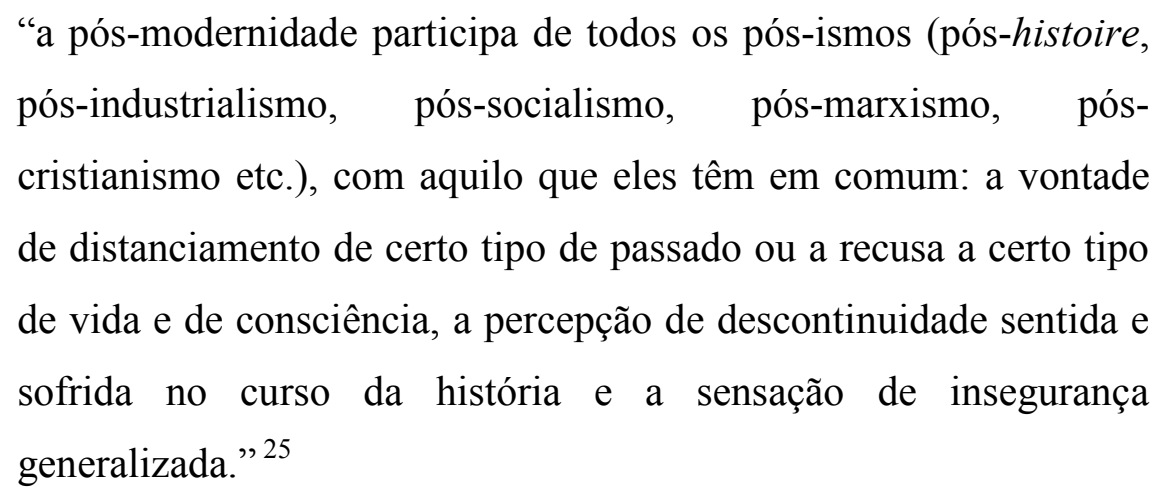

Luís Roberto Barroso $^{26}$ corrobora com a idéia de ruptura com o sistema construído na modernidade, ao afirmar que "entre luz e sombra, descortina-se a pósmodernidade; o rótulo genérico abriga a mistura de estilos, a descrença no poder absoluto da razão, o desprestígio do Estado; (...) uma época pós-tudo: pós-marxista, pós-kenseniana, pós-freudiana".

Eduardo Bittar $^{27}$ debruçou-se sobre o tema, tratando-o com a necessária profundidade. Trouxe importante contribuição para a construção da doutrina pós-moderna, dando enfoque preciso para o fenômeno:

"A dificuldade de pensar tempos de indefinição é ainda maior, pois
estes tempos marcados pela erosão de valores, pela alteração de
parâmetros de comportamento, pela decrepitude e pela inadequação
das instituições aos desafios presentes, pelas mudanças sócio-
econômicas, pelas crises simultâneas que afetam diversos aspectos
da vida organizada em sociedade, pela explosão de complexidade

25 BOFF, Leonardo. A voz do arco-íris. Rio de Janeiro: Sextante, 2004. p. 10.

26 BARROSO, Luís Roberto. A nova interpretação constitucional: ponderação, direitos fundamentais e relaçõos privadas. 2. ed. Rio de Janeiro: Renovar, 2006. p. 4.

27 BITTAR, Eduardo C. B. O direito na pós-modernidade. Rio de Janeiro: Forense Universitária, 2005. 
provocada pela emergência de novos conflitos sócio-institucionais, pela re-qualificação dinâmica dos modos de produção, pelas alterações profundas nos modos tradicionais de se conceber $\mathrm{o}$ ferramental jurídico para a construção de regras sociais. ${ }^{, 28}$

O autor descreve a pós-modernidade como reação às aflições concretas da vida contemporânea - desigualdades sociais, injustiça, opressão - e "processo de ruptura, como modo de se diferenciar e de se designar com clareza o período de transição irrompido no final do século $\mathrm{XX}$, que tem como traço principal a superação dos paradigmas erigidos ao longo da modernidade" 29 .

Deste matiz de pensamentos acerca da doutrina pós-moderna, verifica-se que se trata de um movimento de reação ${ }^{30}$ e de progresso, e, seguindo o processo habitual, a pósmodernidade começa a ser reconhecida na Filosofia. No entanto, a regulação dos efeitos de um novo modo de pensar recai sobre o Direito", "que é desconstruído, fragmentado, triturado", porque há um rompimento com as chamadas "verdades absolutas", típicas do modernismo, sustentadas pelo racionalismo exacerbado. Eis a complexidade transformadora do comportamento, do modo de ver e de interpretar as leis, abrindo-se a mente racional para um movimento plural, de possibilidades..

Para Erik Jayme, a expressão da doutrina pós-moderna dá-se com o choque do novo, que passa a ser visível especialmente na arquitetura, em que o construído deseja narrar a função. Isso explica que:

28 BITTAR, Eduardo C. B. O direito na pós-modernidade, p. 6.

29 BITTAR, Eduardo C. B. O direito na pós-modernidade, p. 97.

30 A palavra pós-modernidade é uma herança das artes plásticas, que veio como expressão de uma justaposição de estilos como princípio de criação, numa atitude estética de colagem, integrando o clássico e o moderno. Um exemplo polêmico foi o da pirâmide de vidro construída na entrada principal do Museu do Louvre. Um artista pós-moderno pretende ultrapassar a modernidade naquilo que ela rejeita da tradição. Quando os modernos transgridem as regras dos antigos, os pós-modernos inventam novas regras.

31 CARBONNIER, Jean. Sociologie juridique, p. 145. 
"um restaurante, que deseja fazer publicidade para seu pato assado, seja construído em forma de pato; antes motivo de chacota, agora respeitado - aparece como expressão de uma nova alegria de viver, que quer ser contada. A nova vivência exige uma narração, quer narrar suas experiências". ${ }^{32}$

Em síntese, Jayme atribui ao pensamento doutrinário, como valores pósmodernos, o pluralismo, a comunicação, a narração, e le retours des sentiments, ou revival, cuja tradução de sentido mais apurado é "valorização das lembranças", daí o retorno dos sentimentos como valorização do sentir (no modernismo, a valorização era só do pensar). Observe-se que a compreensão desses pensamentos enseja uma mudança de perspectiva de desconstrução do Direito, diante do rompimento com as verdades absolutas, verdades estas possíveis apenas numa perspectiva singular. Para o autor, "o saber pós-moderno não é apenas o instrumento dos poderes. Ele refina e reforça nossa capacidade de suportar o incomensurável (infinito)"33.

\subsection{VALORES PÓS-MODERNOS}

Erik Jayme empresta valiosa colaboração para a compreensão do conceito da doutrina pós-moderna, por meio da estratificação dos valores que identificam o pensamento norteador do Direito, mostrando o pensamento norteador de tais características.

32 JAYME, Erik. Visões para uma teoria pós-moderna do direito comparado. Revista dos Tribunais, São Paulo, n. 759, 1999, p. 24.

33 JAYME, Erik. RT, ano 88, n. 764, jun. 1999, apud MARQUES, Claudia Lima; CHAPACUZ, Maria Cláudia; VITÓRIA, Ana Paula da Silva. Igualdade entre os filhos no direito brasileiro atual: direito pósmoderno? Revista dos Tribunais, São Paulo, n. 764, p. 11-32, 1999. 


\title{
2.2.1 Pluralismo
}

O primeiro valor pós-moderno exaltado por Jayme é a perspectiva da pluralidade de estilos de vida e a negação de uma pretensão universal à maneira própria de ser. $\mathrm{Na}$ linguagem do direito, "pluralismo significa ter à disposição alternativas, opções, possibilidades".

Nesta ótica, há o reconhecimento de um pluralismo de fontes, sejam elas legislativas, de sujeitos de direito a proteger, de filosofias, enfim, são incontáveis as alternativas. Claudia Lima Marques acentua que no Direito de Família, sob a ótica pósmoderna:

\footnotetext{
"o pluralismo de fontes pode ter sua origem no reconhecimento de direitos individuais dos membros destas uniões ou grupos (...). Tempos que alternam o ponto de concentração do direito de família, em que se deixa de pensar na manutenção da instituição, mas não dos indivíduos, nos vínculos que ligam este grupo e nos direitos fundamentais de cada um, especialmente dos mais fracos, como as crianças, os filhos". 34
}

\subsubsection{Comunicação}

A comunicação irrestrita é o segundo valor pós-moderno, conforme Erik Jayme:

\begin{abstract}
“associado à valorização extrema do tempo, do direito como instrumento de comunicação, de informação, como valorização de passar o tempo nas relações humanas, valorização do eterno e do transitório, do congelar momentos e ações para garantir a proteção
\end{abstract}

34 MARQUES, Claudia Lima; CHAPACUZ, Maria Cláudia; VITÓRIA, Ana Paula da Silva. Igualdade entre os filhos no direito brasileiro atual: direito pós-moderno?, p. 14. 
dos mais fracos e dos grupos que a lei quer privilegiar. A comunicação é o método de legitimação, a ética e a filosofia são discursivas, o consentimento legitimador é só aquele informado e esclarecido". 35

Embora Jürgen Habermas ${ }^{36}$ não se considere pós-moderno e se declare ainda comprometido com os ideais da modernidade, ligado à Escola de Frankfurt, alguns pensadores, a exemplo de Jean Carbonnier, reconhecem nele a expressão da pósmodernidade. A contribuição de Jürgen Habermas ${ }^{37}$ para a construção da teoria pósmoderna decorre da idéia de que a verdade não é um bloco pré-constituído, como uma estátua, mas que ela se constitui, pouco a pouco, pela discussão, pela comunicação. Tratase, enfim, do agir estratégico e do agir comunicativo, entre a razão estratégica e a razão comunicativa, entre a razão instrumental e a razão dos valores. Portanto, a comunicação é a perspectiva plural, criativa.

O pensamento de Jürgen Habermas assemelha-se à dos preocupados com aspectos ligados à subjetividade e intersubjetividade: elemento indicador da intenção, em oposição ao valor advindo do estruturalismo sistemático, tendente a excluir o sujeito, como em Hans Kelsen, que, ao construir a teoria pura do Direito, afasta totalmente o sujeito.

É contribuição à pós-modernidade a idéia de Jürgen Habermas acerca de círculo da vida, a vitalidade, articulando a integração do sujeito e do objeto. Segundo o autor, não existe o sujeito de um lado e o objeto do outro, mas a intencionalidade da consciência pressupõe, fundamentalmente, que nenhum objeto existe sem o sujeito e que nenhum sujeito existe sem o objeto. Nessa relação, não se pode reduzir um ao outro, pois são dinâmicos entre si, comunicam-se formando a intersubjetividade.

35 JAYME, Erik. $R T$, ano 88, n. 764, jun. 1999 apud MARQUES, Claudia Lima; CHAPACUZ, Maria Cláudia; VITÓRIA, Ana Paula da Silva. Igualdade entre os filhos no direito brasileiro atual: direito pósmoderno?, p. 14.

36 CARBONNIER, Jean. Sociologie du droit, p. 158-159.

37 HABERMAS, Jürgen apud CARBONNIER, Jean. Sociologie juridique, p. 158. 
A intersubjetividade é a razão comunicativa, o mundo da vida ${ }^{38}$, que é toda a expressão do homem, no sentido mais variado, seja religião, ciência, dignidade, ética. $\mathrm{O}$ mundo da vida tem que compor com a personalidade, com as pessoas, com a individualidade sentida internamente, a dimensão das vivências subjetivas. O mundo da vida, da subjetividade, o mundo consciente, o mundo inconsciente, e também toda a dimensão material do homem, como são todas as instituições, as cidades, o direito, as dimensões do Estado, da família, das crenças, e assim sucessivamente.

\subsubsection{Narração}

O terceiro valor da doutrina pós-moderna, apontado por Jayme, é a "narração", decorrente do impulso de comunicação, de informação, que invade a Filosofia do Direito e as próprias normas legais".

A mudança paradigmática contém, em sua essência, a busca da alegria de viver. Esta experiência quer ser contada, narrada. A lei do Direito de Família pós-moderno deve narrar seu efeito útil, seu sentido, seus princípios, suas finalidades, possibilitando uma interpretação teleológica.

Por este enfoque, merece destaque o Estatuto da Criança e do Adolescente - ECA, que contém normas narrativas. Segundo Maria Cláudia Lima Marques, o artigo 19 do Estatuto "que estabelece o princípio máximo de manutenção de vínculo familiar, mais parece um discurso político, um programa de ação, do que uma norma de conduta geral e auto-aplicável" ${ }^{\prime 0}$.

Fica afastada a descrição de condutas, estas próprias para comportamentos universais, verdades absolutas, que orientaram os paradigmas da modernidade. Na pós-

38 HABERMAS, Jürgen apud CARBONNIER, Jean. Sociologie juridique, p. 34.

39 MARQUES, Claudia Lima; CHAPACUZ, Maria Cláudia; VITÓRIA, Ana Paula da Silva. Igualdade entre os filhos no direito brasileiro atual: direito pós-moderno?, p. 16.

40 MARQUES, Claudia Lima; CHAPACUZ, Maria Cláudia; VITÓRIA, Ana Paula da Silva. Igualdade entre os filhos no direito brasileiro atual: direito pós-moderno?, p. 17. 
modernidade, a lei deve corresponder à fluidez e à narratividade, ampliando o papel do intérprete e do aplicador da norma.

Walter Benjamin ${ }^{41}$ acentua que "a arte de narrar está definhando porque a sabedoria - lado épico da verdade - está em extinção". É claro que, na pós-modernidade, este valor foi retomado, em decorrência do retours des setiments, da volta da emoção.

\begin{abstract}
“A experiência que passa de pessoa a pessoa é a fonte a que recorrem todos os narradores. E entre as narrativas escritas, as melhores são as que menos se distinguem das histórias orais contadas pelos inúmeros narradores anônimos".
\end{abstract}

A narrativa expressa também outro valor da doutrina pós-moderna: a comunicação. Afinal, o narrador retira da sua própria experiência, ou da experiência do outro, o que ele conta, incorporando as coisas narradas à experiência dos seus ouvintes.

Para maior compreensão, Benjamin estabelece uma criteriosa distinção entre narrativa e informação, esta valorizada pela imprensa, um dos instrumentos mais importantes na consolidação da burguesia, no alto capitalismo. Segundo ele, "a informação só tem valor no momento em que é nova. Ela só vive nesse momento, precisa entregar-se inteiramente a ele e, sem perda de tempo, tem que se explicar nele". Já a narrativa pode ser contada de novo. É como uma música que pode ser cantada durante séculos - a exemplo dos clássicos -, pois renasce a cada interpretação. A narrativa não comporta explicações, pois, criativa, deixa para o ouvinte ou leitor a liberdade de interpretar o conteúdo de acordo com sua forma de se emocionar, "e com isso o episódio narrado atinge uma amplitude que não existe na informação. Cada história é o ensejo de uma nova história, que desencadeia uma outra, que traz uma quarta etc.; essa dinâmica ilimitada da memória é a da constituição do relato, com cada texto chamando e suscitando outros textos" ${ }^{\text {"42. }}$.

41 BENJAMIN, Walter. Magia e técnica, arte e política. 7. ed. São Paulo: Brasiliense, 1994. p. 198-213.

42 BENJAMIN, Walter. Magia e técnica, arte e política, p. 86. 
A circulação da informação chegou a tal intensidade com o advento da internet, que a notícia torna-se cada vez mais efêmera. Criam-se sistemas, há poucos anos impensáveis, de satisfação de uma demanda insaciável, viciada em obter notícias, pelo momento da notícia, e não exatamente pelo seu conteúdo. Este fenômeno merece uma reflexão e, com certeza, embora Benjamin não tenha alcançado o terceiro milênio, há resposta em sua obra, cujo saber ainda é novo.

Seguramente, Benjamin já apontou a gravidade deste sintoma, de desvio da expressão humana, ao apontar que:

\footnotetext{
"a idéia de eternidade sempre teve na morte sua fonte mais rica. Se essa idéia está se atrofiando, temos que concluir que o rosto da morte deve ter assumido outro aspecto. Essa transformação é a mesma que reduziu a comunicabilidade da experiência à medida que a arte de narrar se extinguia".
}

\subsubsection{Retour des sentiments ou revival}

O quarto valor em exame é o retour des sentiments, ou, como afirma Jayme, um revival dos direitos humanos, revalorizados nesta transição de doutrina moderna para pósmoderna, porque é a única segurança para o caos de um direito "desconstruído, fragmentado, triturado", como bem expressou Jean Carbonnier. Trata-se, enfim, de permissividade de uma certa "emocionalidade no discurso jurídico", impensável na doutrina norteada pelo racionalismo, na modernidade.

É justamente quando se descortinam os valores pós-modernos e o revival aos direitos fundamentais, e "esses direitos constitucionais influenciam o direito privado a ponto de o direito civil assumir um novo papel social", que o princípio da dignidade da pessoa humana sinaliza novos tempos, desenvolvendo-se como conceito jurídico, passando a integrar as constituições dos países ocidentais, a começar pela Alemanha. O Brasil logo 
acompanhou a tendência pós-moderna, ao acolher o axioma no artigo $1^{\circ}$, III, da Constituição Federal de 1988.

Deve-se, porém, a Jean Carbonnier a sistematização desse fenômeno graças ao que escreveu sob o título "A pulverização do Direito em Direitos Subjetivos”, incluído na obra de sua autoria intitulada Droit et passion du droit sous la V. ème République:

"É a segunda guerra mundial que deu vigor aos direitos subjetivos. O regime nazista os oprimiu tanto que quando foram liberados eles explodiram. A Constituição de 1946 (francesa) tem por preâmbulo uma declaração de direitos (subjetivos) ditos da segunda geração; e, em 1948 a ONU fez dos direitos do homem uma Declaração Universal." 43

O efeito não foi imediato, pois os reflexos só apareceram muito tempo depois, quando da interpretação de vários dispositivos legais, como o pátrio-poder que, na França, passou a ter a denominação autoridade parental - que pertence aos pais (direito subjetivo) para uma certa finalidade social (proteção da criança). Há aspectos de um direito, e de um dever, concomitantemente.

Jean Carbonnier é um lídimo representante da doutrina pós-moderna ${ }^{44}$ nas ciências jurídicas, construindo esta passagem entre o direito orientado pela doutrina moderna, racionalista e o direito norteado pela doutrina pós-moderna, trazendo à análise, os dispositivos legais e os reflexos da mudança de um comportamento libertário, valorizado pela pulverização dos direitos subjetivos, pelo revival, pela emocionalidade, pela revalorização dos direitos fundamentais.

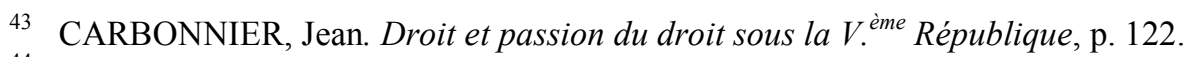

44 CARBONNIER, Jean. Sociologie juridique, p. 147. "La même ambiguïté plane sur la médiation, cette fille putative de la postmodernité moderne: de gauche, parce que justice populaire ; de droite, parce qu'un juge d'Etat pourrait être, pour les faibles, plus protecteur". 
O fenômeno da pós-modernidade reflete-se, indefectivelmente, na família pósmoderna, cujo conceito somente pode ser apreendido quando estudada sua dinâmica pelos valores da pós-modernidade. 


\section{A FAMÍLIA NA PÓS-MODERNIDADE}

\subsection{PARA ONDE VAI A FAMÍLIA?}

Jean Carbonnier ${ }^{45}$ fez esta indagação bastante norteadora para a localização do estado da arte do tema em exame: "há cem anos, os cientistas perguntavam-se de onde vem a família; hoje eles se adiantam para perguntar para onde ela vai”.

Depois de analisados os quatro valores da cultura pós-moderna, segundo Erik Jayme, norteadores de um modo de identificação da doutrina pós-moderna e sua respectiva escala valorativa essencial, observa-se que, já há várias décadas, o fenômeno do crescente individualismo na família faz-se presente na história dos usos e costumes e na expressão dos direitos subjetivos. A lei porém, nem sempre acompanhou o processo evolutivo, permancendo com paradigmas de outra época.

\subsection{RETRATO DA FAMÍLIA}

O fenômeno do individualismo na família ocorre porque, na modernidade, o Direito valorizava a instituição da família, e, na pós-modernidade, o Direito valoriza o sujeito. Os membros da família são vistos em sua individualidade e em relação às funções familiares, sempre norteadas pelos respectivos direitos fundamentais:

45 CARBONNIER, Jean. Flexible droit, p. 224: Les savants d'il y a cent ans se demandaient d'où elle venait; ceux d'aujourd'hui demendent plutôt où elle va. 
"O nascimento ou reconhecimento de novos sujeitos na família inverte o ponto de concentração do direito, da instituição como um todo, para as partes, para os sujeitos individualmente considerados, em um novo pluralismo de sujeitos. Schwab chega a mencionar a família como o 'ponto de encontro' de direitos individuais" ${ }^{\text {"46. }}$.

Os reflexos da "inversão do ponto de concentração do direito de família" ensejaram, em 1994, a realização da Conferência Mundial da ONU que teve como tema o "Ano Internacional da Família". A contribuição da França, na preparação desta conferência, consubstanciou-se em criteriosa pesquisa para vislumbrar o perfil da família do terceiro milênio. Assim, em janeiro de 1994, o Instituto da Infância e da Família (França) organizou um simpósio, tendo como tema "Famílias e Pesquisas: novas questões, novos encontros, novas descobertas", sob o patrocínio da Unesco, da Comissão da União Européia e do governo francês.

O resultado das reflexões desenvolvidas durante o simpósio foi publicado na obra coletiva intitulada Droit et famille ${ }^{47}$, cujas conclusões evidenciam a adoção e o reconhecimento de uma família, cujo perfil é pós-moderno, afinal, estão presentes na família os quatro valores que, segundo Erik Jayme, caracterizam a doutrina (pluralismo, comunicação, narração e le retours des sentiments ou revival).

A comissão científica teve por objetivo descrever a família intrinsecamente, em suas relações intersubjetivas, não interessando mais ao Direito de Família apenas a realidade extrínseca como célula mater da sociedade, formadora da rede social, que legitima a formação do Estado.

46 HABERMAS, Jürgen, apud MARQUES, Claudia Lima; CHAPACUZ, Maria Cláudia; VITÓRIA, Ana Paula da Silva. Igualdade entre os filhos no direito brasileiro atual: direito pós-moderno?, p. 17.

47 STECK, Philippe. Droit et famille. Paris: Economica, 1997, coordenada pelo autor. Trata-se de uma obra coletiva que os franceses chamam mélanges, misturando vários autores e textos, desenvolvendo, com profundidade, um determinado tema. As pesquisas revelam que os leitores não querem mais os grandes tratados, contendo apenas uma visão. Preferem obter várias opiniões sobre o mesmo tema. Deve ser influência da pós-modernidade. 
Neste contexto, na pós-modernidade, a família, vista no enfoque de célula mater da sociedade, deve ser alvo de políticas sociais e objeto de estudo da sociologia jurídica. Assim, a família é estudada no ponto de vista extrínseco; diferentemente, na modernidade, o Direito de Família tinha como objeto as relações advindas da família extensa, pois importava o aspecto produtivo daquela unidade econômica e as relações patrimoniais a ela inerentes. As relações intrínsecas da família eram objeto da Psicologia, da Psicanálise etc.

No entanto, o retrato da família pós-moderna e, por conseqüência, o retrato do Direito de Família nos derradeiros anos do século $\mathrm{XX}^{48}$, é a pessoa e seu desenvolvimento humano nas relações familiares, estabelecendo "uma dialética, por vezes, sutil, entre o Direito e os usos e costumes" 49 .

A distinção que se pretende fazer está bem definida pelas palavras de Hannah Arendt $^{50}$, ao opor duas instâncias: o público e o privado. Elas constituem duas dimensões fundamentais do ser no mundo: a esfera doméstica, na qual se faz a manutenção da vida, sua gestão e sua transmissão (relações intrínsecas da família), e a esfera política, em que se faz uma transferência da experiência pessoal, exercendo o ato de dar um sentido à própria existência, para a livre construção do futuro da humanidade (relações extrínsecas da família).

No início da pesquisa da França, já mencionada, imaginava-se que o prestígio e a importância da família, como organização de vida para as novas gerações, estariam em queda. Ao contrário, porém, colheram-se dados reveladores de que a maioria dos jovens contemporâneos reconhece na família o melhor caminho para os projetos de futuro. Além disso, a vida conjugal ainda exerce importante atração como garantia de felicidade. Outro dado relevante colhido nesta pesquisa, que serviu de alicerce para o simpósio, é que os

48 Como o Simpósio ocorreu em 1994, ainda não havia, portanto, a previsão projetiva da primeira década do século XXI.

49 STECK, Philippe. Droit et famille, p. 9.

50 LAFER, Celso. A reconstrução dos direitos humanos. São Paulo: Companhia das Letras, 1988. Relata o pensamento de Hannah Arendt, em capítulo dedicado à filósofa sob o título: "Hannah Arendt, a ruptura totalitária e a reconstrução dos Direitos Humanos". 
franceses e as francesas têm como conceito de família o lugar onde se sente bem em estar junto $^{51,52}$.

O simpósio deu origem aos chamados "princípios sintéticos", norteadores de uma conduta para o desenvolvimento e atualização do Direito de Família. Tais princípios resumem-se em:

“- reforçar as parcerias entre especialistas, numa relação interdisciplinar, na busca de um conhecimento de natureza transdisciplinar para a compreensão do conflito familiar, de acordo com o crescente personalismo do Direito Civil da Família e da leitura que se pode fazer do fenômeno;

- reforçar a consciência de que ainda há muito a aprender sobre família, nesta relação de ampliação interdisciplinar;

- reforçar o nível de qualidade do diálogo entre pesquisadores, institutos, universidades e aqueles que decidem sobre a família;

- reforçar a atitude da família para que ela mesma supra as suas necessidades, responsabilizando-se por suas escolhas, compreendendo-as sem recorrer a terceiros, como ao Judiciário, a quem entregam a autoria de suas vidas;

- reforçar a atitude de reconstrução da noção de interesse da criança;

- reforçar as reflexões acerca da grande revolução do século XX, consubstanciadas na evolução dos direitos da mulher ${ }^{53}$ ".

51 STECK, Philippe. Droit et famille, p. 1

52 MEULDERS-KLEIN, Marie-Thérèse. Liber amicorum, cuja definição de família merece ser repetida, pois traduz, com precisão, a valoração da família pós-moderna, conclusão da pesquisa realizada do Ano Internacional da Família em 1994: "Família é o principal lugar de felicidade".

53 BARBOSA, Águida Arruda. A mulher na área jurídica: família. In: AUAD, Sylvia Maria von Atzingen Venturoli (Org.). Mulher: cinco séculos de desenvolvimento na América. Belo Horizonte: O Lutador, 1999. p. 245-287. 


\title{
3.3 A FAMÍLIA EM ORDEM
}

Jean Carbonnier, ao analisar as dinâmicas da família e suas fases de transformação, a exemplo do aparecimento do divórcio, parte do ponto de vista de que, para compreender o conflito familiar, antes é preciso compreender e descrever a família em $\mathrm{ordem}^{54}$. Assim se pronuncia o civilista interdisciplinar, ao explicar a sociologia do divórcio:

\begin{abstract}
"Da mesma forma que a sociologia criminal sofre um desvio, limitando sua pesquisa aos delinqüentes, sem se preocupar com os não-delinqüentes, faltará alguma coisa de essencial à sociologia do divórcio, se ela considerar somente os divorciandos: são os nãodivorciandos que os divorciam." ${ }^{, 55}$
\end{abstract}

Segundo Jean Carbonnier, a família em ordem reflete a Biologia ${ }^{56}$. Sua constituição apóia-se em dois eixos: a conjugalidade, como expressão da sexualidade humana, e a filiação, como expressão da genética. Vista nesta ótica, a história da família coincide com a das conquistas científicas de cada época. Esta análise sociológica da família repousa em duas assertivas do autor:

\begin{abstract}
"para a sociologia, a família é um grupo elementar formado por indivíduos vinculados por motivação de ordem biológica: união de sexos, procriação e descendência de um procriador comum; este grupo tem uma estrutura, mas é um grupo vivo, animado pelas funções ${ }^{57}$ que ele exerce no corpo social”.
\end{abstract}

54 ROUDINESCO, Elisabeth. A família em desordem. Tradução de André Telles. Rio de Janeiro: Zahar, 2003. Em contraponto ao título desta obra, que será objeto de análise, em seguida, é coerente falar de família em ordem, quando Jean Carbonnier exalta a necessidade de se estudar o não delinqüente para compreender o delinqüente, a família também deve ser estudada pelo ponto de vista dos não divorciandos, para compreender os divorciandos e os conflitos familiares, de um modo geral.

55 CARBONNIER, Jean. Sociologie juridique, p. 204.

56 CARBONNIER, Jean. Droit civil, p. 15.

57 LAFER, Celso. A reconstrução dos direitos humanos, p. 40, cita o pensamento de Hannah Arendt. Para a autora, os homens eram compelidos à vida familiar por suas necessidades e carências, pois a vida, para manutenção individual e sobrevivência da espécie, requer a companhia dos outros. $\mathrm{Na}$ antiguidade, era 
O sentido da família completa-se pela relação do papel biológico e do papel das funções sociais, compreendendo, aí, as relações humanas com dois indivíduos pelo menos.

Há dois ciclos da família, segundo a rede afetiva que une os seus integrantes ${ }^{58}$ :

- família clássica, estruturada na hierarquia vertical, na rígida divisão de tarefas e centrada no matrimônio como base para a procriação, ou seja, trata-se de uma família enfocada no passado, na árvore genealógica;

- família nuclear, que se limita ao casal e aos descendentes menores, na qual desaparece a hierarquia e a divisão de papéis, ganhando na qualidade do afeto, pois, o afastamento da família tronco passou a permitir que a sociedade conjugal tivesse prioridade, com a intensificação da vida erótica, uma família norteada para o futuro.

O estudo da família pós-moderna tem a família nuclear como alvo de aprimoramento, ao contrário da era da modernidade, na qual a família era extensa, com enfoque patrimonial.

A constituição da família gera funções de três níveis, confundindo-se com os próprios efeitos do casamento ${ }^{59}$ : efeitos pessoais, patrimoniais e sobre a pessoa dos filhos, traduzindo-se em função relativa aos direitos e deveres entre os cônjuges, função relativa à base econômica da família e função parental ou de responsabilidade com a prole.

evidente que a manutenção individual era tarefa do homem e a sobrevivência da espécie era tarefa da mulher. Essas funções naturais, o labor do homem no suprimento de alimentos e o labor da mulher no parto, eram sujeitas à mesma premência da vida.

58 CARBONNIER, Jean. Droit civil, p. 15.

59 CARBONNIER, Jean. Droit civil, t. 2, p. 159. 
Para exemplificar uma função da família, Giselle Groeninga ${ }^{60}$ elucida acerca das funções de pai e mãe, em torno do lugar da criança:

"Levando-se em conta os níveis inconscientes de ligação em uma família, vemos que a criança ocupa, muitas vezes, o lugar não de projeto, mas de ‘projeção' - mecanismo psíquico segundo o qual se atribui o que é de si próprio ao outro, como características, desejos, afetos. Assim, assistimos, muitas vezes, à criança passando a ocupar lugar central em uma família em detrimento do lugar central do casal e das responsabilidades que lhes cabem. Infelizmente, em um certo número de casos, os casais desaparecem dando lugar aos pais. Casais sem amor ou famílias monoparentais estão aí para testemunhá-lo. Aparece, assim, a criança que acaba por importunar, não aquela com a qual devemos nos importar."

Para Eduardo de Oliveira Leite, a família nuclear ${ }^{61}$ vem a ser uma relação voltada ao amor, ao afeto, à verdade e à igualdade. Desaparece a hierarquia, dando lugar à linearidade dos sentimentos e ao companheirismo. A finalidade do casamento, ou da união livre, passa a ser a sociedade conjugal, livre do poder até então exercido pelas relações parentais. Restringe-se ao grupo formado pelo casal e pelos filhos que vivem sob o mesmo teto. O sentido da família nuclear, para o autor, é de trocas afetivas, e, com os modernos métodos contraceptivos, cada vez mais seguros e de fácil uso, há mais liberdade para a sexualidade, o que exerce profundos efeitos sobre a vida conjugal, principalmente para a mulher, que tem o comando da procriação. A prioridade do casal é o companheirismo e a busca do livre desenvolvimento da personalidade.

60 GROENINGA, Giselle. Do interesse à criança ao melhor interesse da criança. Contribuições da mediação interdisciplinar. Revista do Advogado, São Paulo, AASP, n. 62, mar. 2001 (Coordenadação de Lia Justiniano dos Santos).

61 LEITE, Eduardo Oliveira. Temas de direito de família. São Paulo: RT, 1994. p. 18-19. 
O conflito familiar nasce do desvio de função ${ }^{62}$ de algum dos papéis da família nuclear. Sobre a formação do casal conjugal, Jean Carbonnier exalta que cada um se casa dentro do seu meio - por meio da combinação de elementos diversos como território, classe social, profissão, nível de instrução, ideologia política, crença religiosa etc.:

\author{
"Os bailes são o nascedouro de uma série de casamentos, pois, só \\ vão ao mesmo baile aqueles que já pertenciam, anteriormente, a um \\ meio que os torna predestinados a dançar juntos (...). Tudo se \\ desenvolve sob a aparência de que a sociedade trabalha a favor do \\ sucesso dos casamentos. Assim, antes da livre manifestação de \\ vontade de um homem e de uma mulher se unirem, há a vontade
}

62 KEHL, Maria Rita. Em defesa da família tentacular. In: GROENINGA, Giselle; PEREIRA, Rodrigo da Cunha (Coord.). Direito de família e psicanálise rumo a uma nova epistemologia. São Paulo, Imago, 2003. p. 214 "As funções familiares são insubstituíveis. É verdade que as demandas pelos direitos constitucionais dos casais homossexuais, por exemplo, revelam a tendência a reproduzir os papéis familiares tradicionais - pai, mãe, filhos. Só que esses papéis não são mais, necessariamente, desempenhados pelas pessoas que, na estrutura de parentesco, correspondem a pai, mãe e filhos. $O$ máximo que podemos pensar é que, se existir para a criança alguém que faça função paterna e alguém que se encarregue amorosamente dos cuidados maternais, a família estruturará edipicamente o sujeito; é dentro dessa estrutura chamada de família que a criança vai se indagar sobre o desejo que a constituiu - o desejo do Outro - e vai se deparar com o enigma de seu próprio desejo. É nesse percurso que ela vai se tornar um ser de linguagem, barrado em relação ao gozo do Outro. Em linhas gerais, isto seria suficiente para constituir seres humanos orientados pela Lei que interdita o incesto, que é aquela que exige de cada sujeito a renúncia a uma parcela de seu gozo para pertencer à comunidade humana. No que diz respeito ao masculino e ao feminino, é no atravessamento edípico que a criança vai se sexuar como macho ou como fêmea - processo que não é mais do que, como brinca Lacan, o de constituir a certeza subjetiva que nos orienta para sabermos se devemos entrar no banheiro das 'damas' ou dos 'cavalheiros'. A brincadeira lacaniana indica que a identidade sexual se afirma no campo da linguagem, e não do corpo. Interdição do incesto e sexuação resumem o papel que a família deve desempenhar na constituição do sujeito. A partir deste ponto, o papel da família na modernidade é formador, no sentido de preparar as crianças para suas responsabilidades em relação às normas de convívio social. A família moderna é aquela centrada sobre o poder do pai a partir do período da abolição das monarquias absolutistas, onde o destino dos súditos era decidido pela vontade do Rei. Ao contrário do que normalmente se pensa, o poder do patriarca burguês é tributário da queda da figura centralizadora do monarca: é nesta transição que a família ganha importância disciplinar, de célula formadora dos cidadãos e perpetuadora das condições do poder. A relação entre a dissolução da família patriarcal, hoje, e a correspondente "dissolução dos costumes", pode se dar por duas vias. A primeira delas vai no sentido do público ao privado. O modelo de socialização que durante quase dois séculos esteve ao encargo da família patriarcal só fazia sentido em sociedades onde havia algum tipo de continuidade entre a vida pública e a vida privada, onde os valores aprendidos e as restrições impostas aos sujeitos no âmbito da família correspondiam a ideais e exigências importantes para o desempenho dos papéis na vida pública. A dissolução do espaço público em vários países do Ocidente - que no Brasil ganha contornos dramáticos - e a passagem de uma ética da produção para uma ética do consumo, entre outros fatores, são os grandes responsáveis pela desmoralização da transmissão familiar dos valores, e não o contrário." 
social, que exerce uma magia nesta pretensa manipulação dos indivíduos, por meio de forças ocultas. ",63

\subsection{A FAMÍLIA EM DESORDEM ${ }^{64}$}

O conflito familiar não pode mais ter o enquadramento limitado à tecnicidade jurídica de paradigmas já ultrapassados - como a culpa, que ainda permanece em muitas legislações - depois de aberto um universo de conhecimento ilimitado, com fundamentos na interdisciplina, quando a ciência, como paradigma ou na física quântica reconhecendo que a única certeza é a existência de múltiplas possibilidades. Não há mais certeza absoluta para os novos paradigmas do conhecimento.

É preciso reconhecer e identificar a família em desordem ${ }^{65}$, desconstruída, recomposta, homoparental, clonada, gerada artificialmente.

\subsubsection{Família monoparental e família reconstituída ou recomposta}

Em relação a estas novas configurações da família, vale realçar a idéia de família monoparental e recomposta.

63 CARBONNIER, Jean. Flexible droit" p. 203 "Chacun se marie dans son milieu - notion composite où se combinent, du reste, des éléments divers; le territoire, la classe , la profession, le niveau d'instruction, l'idéologie politique, la croyance religieuse. Cela n'empêche pas que les bals ne soient l'occasion d'une foule de mariages, et certes rien ne donne mieux l'impression de tourbillons aléatoires que la manière dont s'apparient des danseurs. Seulement, ne vont jamais à un même bal que ceux qui, par leurs appartenances antérieures, sont autodestinés à pouvoir danser ensemble". Puis le juriste a conclu: "qu'il y a bien de la magie dans cette prétendue manipulation des individus par des forces cachées". En ce qui concerne le divorce, l'écrivain a fait une analyse qui révèle que: "l'une des deux familles au moins avait désapprouvé l'union (sans doute parce que c'était une union hétérogame, mal assortie), à tel point que maintenant la solution du divorce, loin d'apparaître comme déviance et désordre, apparaît comme le retour à un ordre supérieur?' Mais, la profondeur de ces réflexions sur les causes du divorce est plus nette dans la conclusion "au moins un couple sur trois ou quatre échoue afin que les autres prennent mieux conscience de leur réussite relative, de la fragilité de cette réussite aussi, et par le sentiment de leur précarité renforcent leur cohésion”.

64 TELLES JUNIOR, Goffredo. Direito quântico. São Paulo: Juarez de Oliveira, 2003. p. 186: Bergson explica que tudo quanto chamamos "desordem" é sempre ordem. A desordem tida como ausência de ordem é impossível, por ser intrinsecamente contraditória. Na realidade, a ausência de uma certa ordem não é desordem, mas a presença de "outra" ordem.

65 ROUDINESCO, Elisabeth. A família em desordem, p. 10. 
Famílias monoparental e recomposta, ou reconstituída, são termos que revelam uma família em desordem. Por falta de reconhecimento de que se trata de um conceito novo para o Direito de Família, este modelo familiar ainda não mereceu tutela capaz de inseri-la no ordenamento jurídico. Esta inserção necessita de ampla compreensão conceitual, com suporte em conhecimento interdisciplinar, buscando embasamento na doutrina pós-moderna, dando espaço à família plural. A partir deste conhecimento global, será possível dar eficácia à previsão constitucional desta configuração familiar.

Trazendo o aporte da Psicologia aplicada ao campo da Terapia Familiar, pode-se acentuar que a família ${ }^{66}$ contemporânea é essencialmente relacional, constituída, progressivamente, como um espaço privado, no qual os membros experimentam um interesse crescente de estarem juntos e de compartilharem a intimidade, tornando-se cada vez mais sensíveis à qualidade de suas relações, que serão projetadas nos relacionamentos externos à família. As pautas relacionais humanas são oriundas da família.

A socióloga francesa Irène Théry contempla a família contemporânea ${ }^{67}$ sob o enfoque da pluralidade, diversidade, heterogeneidade, multiplicidade e variedade. No entanto, há um hiato entre a construção teórica, no seio da comunidade científica, e a realidade que se repete e se estrutura, transformando os usos e costumes.

A monoparentalidade é transitória, ocorrendo durante o hiato entre uma família e outra, pois as pessoas têm uma forte propensão a reconstituir a família com novos parceiros.

A tendência humana de buscar a sua inserção familiar leva o indivíduo a formar as chamadas famílias reconstituídas ou recompostas, freqüentemente oriundas de duas monoparentalidades. Há estudiosos, porém, que consideram esta situação fática como família mista, pois cada parceiro e sua respectiva prole continua sendo monoparental,

${ }_{66}$ CUSTEM, Van Chantal. La famille recomposée. Paris: Éditions Èrès, 1998. p. 23.

67 THÉRY, Irène. Les changements et leur perception de "la" famille aux "familles". Problèmes Politiques et Sociaux, França, n. 685, 1992. p. 44. 
relativamente à ausência de uma das figuras parentais. $\mathrm{O}$ novo casal conjugal representa, entretanto, uma nova família, seja ela constituída pelo casamento ou pela união estável.

Na ótica interdisciplinar, constata-se que a família reconstituída ou recomposta é a tendência natural de transformação da família monoparental. A família reconstituída atende, em princípio, o superior interesse da criança, pois, representa uma oportunidade de convivência cotidiana com novas funções parentais ${ }^{68}$. Assim, a função materna pode ser ocupada pela parceira do pai; a função paterna, pelo parceiro da mãe. Enfim, há infinitas relações de afinidade e afeto, que poderão se tornar importantes na formação do caráter das crianças.

A família monoparental aparece no Direito Brasileiro a partir de sua descrição na Constituição Federal de 1988, no artigo 226, § 4: "Entende-se, também, como entidade familiar a comunidade formada por qualquer dos pais e seus descendentes".

Trata-se de uma definição abstrata, que pretende regular as situações cada vez mais crescentes de celibatários com filhos, ou filhos nascidos de uniões livres, que não chegam a se tornar estáveis, ou as chamadas produções independentes, ou famílias transformadas pela ruptura do casal conjugal, decorrentes da separação, do divórcio ou da viuvez.

Os fatores determinantes da monoparentalidade são: a pobreza ${ }^{69}$, a autonomia da mulher e a confiança na renovação da vida conjugal, o que leva à intolerância da vida medíocre, principalmente por iniciativa da mulher.

O tema foi abordado com profundidade por Eduardo de Oliveira Leite, que dedicou uma obra às famílias monoparentais ${ }^{70}$. Tendo em vista sua formação em

68 CUSTEM, Van Chantal. La famille recomposée, p. 18.

69 Fernando Henrique Cardoso em entrevista concedida à Revista L'Expres, edição de março de 2000, p. 14, comemorativa dos 500 anos do Brasil, declarou que a população brasileira que preenche a faixa de extrema pobreza é formada, quase que na totalidade, por mulheres e crianças.

70 LEITE, Eduardo Oliveira. Famílias monoparentais. São Paulo: RT, 1997. 
universidades francesas, o jurista vale-se de sua inserção no ambiente jurídico internacional para trazer sua contribuição.

Oliveira Leite ${ }^{71}$ acentua que a família monoparental tem existência constitucional, mas depende de regulamentação infra-constitucional para que tenha existência no Direito Civil. Como este modelo de família não é reconhecido pelo poder público, há uma forte tendência de agravamento de seu caráter discriminatório, no âmbito social.

Em virtude da falta de regulamentação infra-constitucional, a família monoparental não é alcançada pela máxima constitucional contida no artigo 226, caput, da Constituição Federal, que assegura: "A família, base da sociedade, tem especial proteção do Estado".

Não há enquadre legal para a imensa gama de afinidades oriundas das famílias recompostas. Não há parentesco, sob o ponto de vista jurídico, mas há vínculos que constituem psiquicamente a formação dos membros da família, em sua dinâmica sistêmica. Por exemplo, relações formadas por casais em que ambos trazem filhos de outro leito, e na nova família nuclear vêm a ter filhos comuns. São geralmente chamados "os meus, os teus e os nossos filhos". Estes filhos comuns serão co-irmãos de todos os filhos unilaterais, relativamente ao casal em enfoque. No entanto, eles não têm qualquer parentesco entre si, embora, muitas vezes, tenham sido criados no mesmo núcleo, residindo na mesma casa, compartilhando as mesmas dificuldades, com participação idêntica, direta ou indireta, na aquisição de patrimônio da família, muitas vezes, com investimentos pessoais decorrentes de restrições materiais em prol da poupança destinada a este fim.

Evidencia-se, aí, que há um vínculo afetivo a merecer tutela jurídica. Como esta é uma família em desordem, posto que ampliada pela compreensão de paradigmas ditos pósmodernos, fica excluída do porta-retratos. No entanto, há inegáveis direitos subjetivos, que clamam por direitos objetivos correspondentes.

71 LEITE, Eduardo Oliveira. Famílias monoparentais, p. 338. 


\title{
3.4.2 Declínio da soberania do pai e emancipação da subjetividade
}

\author{
Roudinesco sintetiza a problemática que a autora atribui mediante as seguintes \\ indagações: por que os homossexuais ${ }^{72}$ - homens e mulheres - manifestam o desejo de se \\ normalizar, conforme expressão usada por psicanalistas. E por que reivindicam o direito ao \\ casamento, à adoção e à procriação medicamente assistida ${ }^{73}$ ?
}

Há um incontestável desejo de ter uma família ${ }^{74}$, mas há também uma grande insegurança em relação aos sujeitos destas famílias em desordem.

72 "Se duas pessoas passam a ter vida em comum, cumprindo os deveres de assistência mútua, em um verdadeiro convívio estável caracterizado pelo amor e pelo respeito mútuo, com o objetivo de construir um lar, tal vínculo, independentemente do sexo de seus participantes, gera direitos e obrigações que não podem ficar à margem da lei.” DIAS, Maria Berenice. União homossexual: o preconceito e a justiça. Porto Alegre: Livraria do Advogado, 2000. p. 80.

72 ROUDINESCO, Elisabeth. A familia em desordem, p. 7.

73 ROUDINESCO, Elisabeth. A familia em desordem, p. 7.

74 “"Perspectiva da família que se justifica pela busca da felicidade e da realização pessoal dos seus indivíduos' Justiça gaúcha confirma adoção de crianças por casal de mulheres homossexuais. A $7^{\text {a }}$ Câmara Cível do TJRS confirmou, por unanimidade, ontem, sentença da comarca de Bagé que concedeu a adoção de duas crianças a um casal de mulheres homossexuais. 'É hora de abandonar de vez os preconceitos e atitudes hipócritas desprovidas de base científica, adotando-se uma postura de firme defesa da absoluta prioridade que constitucionalmente é assegurada aos direitos das crianças e dos adolescentes', apregoou o relator do recurso, desembargador Luiz Felipe Brasil Santos. O recurso em julgamento era uma apelação interposta pelo Ministério Público contra a sentença de primeiro grau, do juiz Danilo Edon Franco. As duas mulheres convivem desde 1998. Uma delas obteve a concessão para adotar dois irmãos biológicos. Atualmente, um está com 3 anos e 6 meses; o outro, 2 anos e 3 meses de idade. Posteriormente à adoção, a companheira ajuizou ação postulando também a adoção dos menores. $\mathrm{O}$ desembargador-relator referiu estudos especializados em diversos países, que - em tese - não detectaram qualquer inconveniente na adoção de crianças por casais homossexuais. 'Mais importa a qualidade do vínculo e do afeto que permeia o meio familiar em que serão inseridas e que as liga a seus cuidadores' lembrou o julgador. Fazendo um comparativo com as uniões entre pessoas do mesmo sexo - convivência duradoura, pública, contínua e com o objetivo de constituir família - o voto concluiu ser possível o reconhecimento do direito de adotar a uniões entre homossexuais. O voto do desembargador Luiz Felipe Brasil Santos é longo e apreciável. Ele rememora que 'temos, no Brasil, cerca de 200 mil crianças institucionalizadas em abrigos e orfanatos. A esmagadora maioria delas permanecerá nesses espaços de mortificação e desamor até completarem 18 anos porque estão fora da faixa de adoção provável. Tudo o que essas crianças esperam e sonham é o direito de terem uma família no interior das quais sejam amadas e respeitadas'. Depois, o voto incursiona no Direito comparado, trazendo conceitos de autores espanhóis, franceses e norte-americanos. O acórdão ainda não foi publicado. Mas foi possível anotar, ontem, na sessão de julgamento que, no entendimento da $7^{\text {a }}$ Câmara, 'tais relacionamentos não se configuram rigorosamente uniões estáveis, mas se assemelham mais a estas que a uma sociedade de fato, pois o que os une é o afeto, não o objetivo de extrair resultados econômicos da relação'. 'Parece inegável que o que leva estas pessoas a conviverem é o amor, cercadas, ainda, por preconceitos' - disse o desembargador Luiz Felipe. Ele destacou o estudo social efetuado, referindo que o laudo comprova saudável vínculo existente entre as crianças e as adotantes. Por fim, louvou a solução encontrada pelo julgador de primeiro grau, que determinou que, no registro de nascimento das crianças, conste que são filhas das duas mulheres, sem especificação de pai ou mãe. A desembargadora Maria Berenice Dias acrescentou que as crianças "têm duas mães, e a Justiça não pode negar isso"" (Proc. n. 70013801592 - com informações do TJRS e da base de dados do Espaço Vital, edição de 6/4/2006). 
A família em desordem reflete a família pós-moderna, e sua regulação enfrenta os efeitos jurídicos de um Direito desconstruído, fragmentado, triturado. Tendo como divisor de águas o rompimento com as verdades absolutas (para admitir que o conhecimento científico do terceiro milênio centra-se nas probabilidades), esta é a complexidade transformadora do comportamento, do modo de ver e de interpretar as leis. Vive-se a crise da razão, abre-se espaço para a intersubjetividade.

O Direito de Família pós-moderno está pendente de reconstrução, livre de preconceitos, para acolher as diferenças.

As novas configurações da família têm sido alvo de atenção da sociedade, preenchendo os noticiários e sendo representadas nas novelas etc.

Para exemplificar esta dinâmica do perfil contemporâneo da família, recorre-se ao artigo "Pai, mãe e filhos"75 que espelha esta tendência ao noticiar que a família normal perde espaço: “de 95 a 2005, perfil tradicional de família diminui de 57,6\% para 50\% do total; cresce proporção de casais sem filhos e mães solteiras".

Maior expectativa de vida e emancipação das mulheres são fatores que explicam essa mudança no cenário do país, apontada pelo IBGE. No caso dos idosos ${ }^{76}$, aumenta o número deles morando sozinhos ou com o cônjuge sem filhos, devido à longevidade. A independência profissional e financeira da mulher acarreta a maternidade tardia, por volta dos 40 anos, limite que a medicina tem ampliado, com segurança cada vez mais ampla, para a saúde da gestante e da criança. Este fato influi no número de filhos, ficando algumas mulheres numa única gestação.

75 SOARES PEDRO, Antonio Góies. Pai, mãe e filhos. Disponível em: < http://www.uol.com.br>. Acesso em: 21 dez. 2006.

76 Confirmando o ensinamento de Jean Carbonnier, a família reflete os avanços da ciência. Observa-se que os idosos do sexo masculino recuperaram a capacidade sexual, com o advento de Viagra e congêneres. Este fato dá ensejo a um fenômeno: divórcios freqüentes de casais com 40, 50 anos de casados. O homem acaba encontrando parceiras mais novas e se sente capaz de fazer projetos para o futuro. No entanto, o emocional não tem acompanhado a aventura, ocasionando incidência de doenças graves, normalmente, degenerativas, para os dois cônjuges: a mulher, pelo inconformismo de ser deixada e o homem pela decepção da realidade. 
Em síntese, a família em desordem decorre dos mecanismos de adaptação à concepção da família ocidental, capaz de lidar com o "declínio da soberania do pai"77 e o princípio da "emancipação da subjetividade". Enfim, trata-se do paradigma do advento da familia afetiva contemporânea.

O modelo patriarcal marcou a família autoritária, mas foi se afastando do paradigma da divindade, deixando de ser sacralizado para ser humanizado. O pai, ao se emancipar como sujeito de direitos subjetivos privilegiados, "forneceu uma imagem invertida de si mesmo, deixando transparecer um eu descentrado, autobiográfico, individualizado"

Assim, é possível extrair a compreensão de que a família em desordem é aquela advinda da queda do modelo patriarcal, marcada pelo retours des sentiments, como já mencionado por Erik Jayme, desenhando a família ocidental contemporânea. Segundo Elisabeth Roudinesco:

\footnotetext{
"a concepção freudiana da família, como paradigma do advento da família afetiva, apóia-se em uma organização das leis da aliança e da filiação que, embora instituindo o princípio do interdito do incesto e da perturbação das gerações, leva todo homem a descobrir que tem um inconsciente e, portanto, que é diferente do que se acreditava ser, o que o obriga a se desvincular de toda forma de enraizamento." 79
}

Diante desta família em desordem, há urgência de reconhecimento jurídico de sua essência, com enquadre de sua realidade à moldura legal, capaz de acolhê-la ao ordenamento jurídico pátrio. 
Elisabeth Roudinesco ${ }^{80}$ conclui, enfim, que a família do futuro deixa a sacralidade para ser um modo de conjugalidade afetiva. Os filhos assistem, com grande freqüência, ao casamento e ao divórcio de seus pais, ruptura que pode ocorrer mais de uma vez, numa proporção de um terço dos casos. As mulheres lideram a iniciativa da ruptura do casal conjugal, suportando os efeitos dela advindos em família monoparental, com a guarda dos filhos. Os casais homossexuais lutam pelo direito de oferecer aos filhos o princípio da diferença sexual, não se contentando com duas mães ou dois pais, para dar lugar à função materna e à função paterna, que legitimam o princípio da aliança.

Dessa forma, o retrato da família contemporânea só pode ser assimilado por uma visão interdisciplinar que possibilite o conceito jurídico de conflito, atribuindo ao afeto valoração de natureza jurídica.

80 ROUDINESCO, Elisabeth. A família em desordem, cit. 


\section{CONFLITO FAMILIAR E AFETO}

\subsection{UMA ABORDAGEM INTERDISCIPLINAR}

Da dicotomia existente entre a família em ordem e a família em desordem extraem-se a compreensão e o entendimento da formação do conflito familiar e do afeto.

O conflito $^{81}$ é um estado provocado pela coexistência de dois estímulos, que disparam reações mutuamente excludentes. A escolha de um estímulo exclui o outro. A crise ocorre quando há uma paralisação que impede a escolha, ou porque os dois caminhos são igualmente conhecidos, ou porque as duas possibilidades existentes são desconhecidas, o que acarreta medo e insegurança.

Aldo Novak descreveu, com clareza, a dinâmica do conflito familiar:

"A vida que você não escolheu, fez de você quem é. Você não escolheu sua família, não escolheu suas experiências de infância, ou algumas da adolescência, não escolheu as dores e traumas pelos quais passou e não escolheu problemas físicos de nascimento ou causados por acidentes. A boa notícia é: parabéns. Se você sobreviveu ao caos, imagine como será sua vida se passar a

81 SILVEIRA BUENO, Francisco da. Grande dicionário etimológico-prosódico da língua portuguesa. São Paulo: Lisa, 1998. p. 791. 
escolher os caminhos, escolher as pessoas e escolher as experiências; enfim, escolher suas escolhas!" ${ }^{82}$

Conforme acentuado por Aldo Novak, a essência da dinâmica das relações que dão origem à dinâmica do conflito humano é a escolha, que será objeto de aprofundamento em capítulo seguinte.

A responsabilidade pelas próprias escolhas, compreendendo que foram feitas em circunstâncias que não comportavam alternativas, é o comportamento adequado para enfrentar os conflitos familiares, que podem, assim, ser transformados. Em decorrência disso, pode haver o fortalecimento das relações e dos vínculos. Há, porém, uma grande trajetória a ser trilhada para qualquer indivíduo chegar a fazer suas escolhas.

A família pós-moderna, conforme já exposto, tem seu sentido voltado à afetividade, esta valorizada como essência do princípio da aliança e da parentalidade. Para compreender o conflito familiar, é preciso, antes, conhecer o conceito interdisciplinar de afeto. Luiz Edson Fachin assim se posiciona a respeito do tema:

$$
\begin{aligned}
& \text { "O sistema jurídico brasileiro vincado por uma axiologia } \\
& \text { principiológica de índole constitucional, e informado por uma visão } \\
& \text { aberta, plural, não exclusivamente matrimonializada da família, } \\
& \text { tomou, sim, o afeto como valor jurídico (......" } 83
\end{aligned}
$$

A palavra afeto ${ }^{84}$, grosso modo, aparece como sinônimo de afeição, simpatia, amizade, amor, sentimento, paixão. Já no sentido psicológico, afeto é o elemento básico da

82 Aldo Novak é um dos primeiros coaches do Brasil, profissão que mistura um pouco de consultoria, de técnico pessoal e de professor. Por sua exposição na TV e rádio, Novak popularizou a profissão no Brasil. Ele também publica uma coluna semanal (www.aldonovak.com.br) lida por cerca de meio milhão de pessoas, chamada "Com o Pé Direito", onde trata de temas como motivação, networking, relacionamento pessoal, relacionamento de casais. "Coaching”. Disponível em: $<$ http://www.wikipedia.org $>$. Acesso em: 12 jan. 2007.

83 FACHIN, Luiz Edson. Entrevista. Boletim IBDFAM, n. 19, ano 3, mar./abr. 2003.

84 SILVEIRA BUENO, Francisco da. Grande dicionário etimológico-prosódico da língua portuguesa, p. 107. 
afetividade: o conjunto de fenômenos psíquicos que se manifestam sob a forma de emoções, sentimentos e paixões.

O desenvolvimento humano dá-se pela alternância de sentimentos, que oscilam entre o amor e a hostilidade - o que afeta - afastando-se, completamente, da indiferença o que não afeta. Na infância, estes sentimentos são dirigidos ao pai e à mãe, de acordo com as fases da vida. Nos primeiros tempos, em virtude do vínculo biológico - gestação e amamentação - os sentimentos de amor são dirigidos à mãe, e os hostis, inicialmente, são dirigidos para aquele que representa o terceiro que interfere nesta relação - o pai biológico, socioafetivo, ou outras instâncias, como a autoridade do Estado.

Conforme enfatiza Rodrigo da Cunha Pereira, para Jacques Lacan:

“o pai é então uma função simbólica de Lei. A função paterna é a organizadora das relações - o que não pode e o que pode, e de que modo pode. Assim, pelo medo da perda do amor do pai e pelo medo da punição deste, o exemplo vai sendo internalizado e, por meio de sentimento de amor e ódio, a criança se constitui psiquicamente." 85

A autoridade da lei sobre o indivíduo é aprendida, porque é cultural e não biológica. As pautas relacionais vividas na família só são possíveis, porque há adultos que exercem a função materna e paterna para aquele indivíduo indefeso e completamente dependente para se manter vivo. Assim, as leis da convivência social refletem a família. A família proporciona a vivência da s diferenças: realidade biológica e realidade psíquica, homem e mulher, adulto e criança, aspectos objetivos e subjetivos, natureza e cultura etc.

O exercício dos papéis parentais - pai e mãe - não se limita a uma relação biológica, mas a uma efetiva dinâmica sistêmica, em que o papel de filho depende da legitimação dos papéis parentais.

85 PEREIRA, Rodrigo da Cunha. Direito de família: uma abordagem psicanalítica. 3. ed. Belo Horizonte: Del Rey, 2003. p. 131. 
A família tem caráter universal e sua constituição é regida pela primeira lei da família: os interditos do incesto, do canibalismo e do parricídio. Esta lei representa o reconhecimento dos semelhantes, na delimitação de lugares e funções, e a "interdição da expressão livre da agressão e da sexualidade, que seria a violência, impondo-se sua simbolização e mediação por meio da palavra e mitigação por meio do amor" ${ }^{\circledR 86}$.

A compreensão jurídica do conflito familiar deve ter como fundamento o conhecimento das fases da vida de um casal conjugal, que, de um modo geral, assim se desenvolvem:

- objetivos comuns, em relação à construção de um projeto de vida, marcado pelo ritual de passagem ${ }^{87}$, que lhes dá a oportunidade de se desligarem da família de origem, elaborando o luto de forma saudável, passando a assumir os papéis e funções que lhe são atribuídos ${ }^{88}$;

- nascimento dos filhos, trazendo a função parental à função conjugal;

- adolescência dos filhos, coincidindo com a crise de meia idade do casal;

- saída dos filhos do convívio doméstico, exigindo que o casal se fortaleça e encontre re-significação (do vínculo conjugal) no novo contexto;

- morte dos avós, trazendo a vivência de luto (num ciclo natural, pois há famílias que vivem a inversão desta experiência, em que a geração mais velha enterra um familiar de geração mais nova);

86 O tema aqui referido tem, como objetivo, apenas demonstrar a importância do conhecimento interdisciplinar acerca do conflito humano, para uma análise mais profunda capaz de ampliar a compreensão da demanda jurídica para a prestação da tutela jurisdicional nos conflitos de família. O Direito pós-moderno exige esta compreensão num movimento plural, com a narrativa adequada à exaltação do sentimento. Giselle Groeninga aborda o tema com maestria em artigo intitulado: Do interesse à criança ao melhor interesse da criança. Contribuições da mediação interdisciplinar.

87 A propósito da importância do ritual do casamento e seus efeitos Darcy Ribeiro elucida que a primeira aliança entre portugueses e índios foi o cunhadismo, etimologicamente originado no latim cognatu, cujo significado, no idioma atual, é a relação de afinidade do irmão de um dos cônjuges em relação ao outro. $\mathrm{E}$ já entre os caboclos, tratamento equivalente a companheiro, amigo, senhor etc. O indígena sempre teve o comportamento peculiar de incorporar estranhos à sua comunidade. Oferecia ao branco uma moça índia como esposa, pois, ao assumi-la como tal, criava laços indissolúveis, já que geravam filhos. E criavam elos consangüíneos e de afinidade com aquela geração, assim como a dos ascendentes e descendentes. Enfim, conforme o significado etimológico do termo, o cunhadismo tinha a propriedade de multiplicar relações a partir de um cognatu, ou seja, conhecido (RIBEIRO, Darcy. O povo brasileiro. São Paulo: Companhia das Letras, 1995. p. 81).

88 A celebração do casamento religioso tem simbolismo muito claro de ritual de passagem, o que se repete no tempo, nas civilizações e na pluralidade de religiões. 
- envelhecimento, doença e morte dos pais, trazendo a consciência do dever de cuidar da geração ascendente.

O importante registro a ser feito, extraído da análise dos ciclos vitais da família, é a observação de que as funções mudam de posição, quando os membros da família assumem novas funções. Além disso, as crises de transição de um ciclo para outro são naturais, mas se não forem adequadamente conduzidas, por exemplo, se não forem oportunamente identificadas pelos membros da família, poderão se acumular à crise seguinte.

Este pode ser um ponto de muita vulnerabilidade da família, cujos sintomas podem aparecer sob a forma de litígio, acarretando a ruptura do casal conjugal. Como o Judiciário não está aparelhado para enfrentar o litígio sob o enfoque interdisciplinar - um conhecimento que amplia as disciplinas em sua extrema especialidade, paradigma da pósmodernidade - a demanda judicial pode contribuir negativamente, tornando o conflito crônico, pois este fica entregue à vontade da lei externa, e não à lei interna de constituição psíquica. Em síntese, há uma paralisação da evolução natural de uma família.

A assertiva que se extrai deste entendimento é que todo conflito familiar é conjugal. O conflito parental não existe sozinho, pois é mera decorrência do conflito entre os cônjuges. Configuram grave desvio de objetivo as ações judiciais que visam obter apenas guarda de filhos, regulamentação de visita e pensão, sem investigar a origem do conflito nos papéis e funções conjugais. Com certeza, a paralisação do casal conjugal não permitiu que, por ocasião do nascimento dos filhos, houvesse a real inclusão da função parental à função marido e esposa. As questões jurídicas relativas aos filhos decorrem de questões inadequadamente enfrentadas pelos pais destes filhos, afinal, trata-se da essência da organização do princípio da aliança e da parentalidade, conforme já exaltado.

Danièle Ganancia, com sua vasta experiência como magistrada na França, expõe:

"a dupla especificidade dos conflitos de família a) o conflito familiar, que antes de ser conflito de direito, é de essência afetiva, 
psicológica e relacional, precedido de sofrimentos; b) seu direcionamento, implicando casais que, após a ruptura, deverão, forçosamente, conservar a relação de co-parentalidade, no interesse das crianças e no seu próprio interesse." 89

Para elucidar a importância do reconhecimento das crises familiares e de uma atitude criativa diante do conflito como oportunidade de desenvolvimento, basta observar a freqüência com que conflitos não elaborados por uma geração são transmitidos à geração seguinte, como um padrão de relacionamento. É, como se costuma dizer, a tendência à repetição de paradigmas, a exemplo da significativa freqüência de divórcios, casamentos tardios, ausência de casamento entre as mulheres ou entre os homens de uma determinada família, que pode culminar na inexistência de descendentes etc.

Dessa reflexão acerca da exteriorização do comportamento entre os membros da família, extrai-se que afeto é tudo aquilo que afeta o desenvolvimento humano, seja para proporcionar condições adequadas para o desenvolvimento da personalidade, seja para reduzir o padrão de oportunidade de qualidade de vida, a exemplo da ementa:

"a dor sofrida pelo filho, em virtude do abandono paterno, que o privou do direito à convivência, ao amparo afetivo, moral e psíquico, deve ser indenizável, com fulcro no princípio da dignidade da pessoa humana" ${ }^{90}$.

89 GANANCIA, Daniele. Justice et médiation familiale: un partenariat au service de la co-parentalité. Gazette du Palais, Paris, 07 jul. 1999, p. 2-7. Traduzido para o português por Águida Arruda Barbosa, Giselle Groeninga e Eliana Riberti Nazareth, publicado na Revista do Advogado, São Paulo, AASP, n. 62, 1999.

90 Trata-se da ementa do acórdão na apelação cível n. 408.550-5, em 01 abr. 2004, Tribunal de Alçada Cível de Minas Gerais, Relator Juiz Unias Silva, que reconhece o princípio jurídico da afetividade. Assim, depreende-se que a responsabilidade não se pauta tão-somente no dever alimentar, mas se insere no dever de possibilitar o desenvolvimento humano dos filhos, baseado no princípio da dignidade da pessoa humana. 


\title{
4.2 UMA ABORDAGEM INTERDISCIPLINAR DO CONFLITO E DO AFETO PELO ENFOQUE DO DIREITO
}

O entendimento interdisciplinar do conflito de família, com apoio na Psicanálise, afasta, definitivamente, o sistema da culpa como fundamento da ruptura em Direito de Família. Culpa de quem? O ministro Antonio Cezar Peluso assim responde:

\begin{abstract}
"Já ninguém é dono de verdades absolutas a respeito do Homem, se é que seja este suscetível de verdades absolutas. De modo que tentar compreendê-lo em estado de sofrimento, como costuma apresentar-se aos profissionais do Direito, nos conflitos que lhe vêm da inserção familiar, é tarefa árdua e, para usar de paradoxo, quase desumana, porque supõe não apenas delicadeza de espírito e disposição de ânimo, mas preparação intelectual e técnica tão vasta e apurada que já não entra no cabedal pretensioso d'algum jurista solitário;",91
\end{abstract}

Eis uma resposta impossível de ser dada, diante dos novos paradigmas que regem a doutrina pós-moderna, como assinala Claudia Lima Marques, para quem o princípio da igualdade entre o homem e a mulher:

"autoriza que se comece a enfrentar a matéria de Direito de Família
a partir de um resgate do 'sentimento', da busca de um maior
humanismo na resolução dos desafios jurídicos que se apresentam.
O retorno ao sentimento busca resgatar um conceito de 'felicidade
individual' em todas as searas jurídicas.",92

91 PELUSO, Antonio Cezar. Direito de família e ciências humanas. São Paulo: Jurídica Brasileira, 1999. (Cadernos de Estudos, n. 1). p. 7.

92 MARQUES, Claudia Lima. Igualdade entre filhos no direito brasileiro atual: direito pós-moderno? Revista dos Tribunais, São Paulo, n. 764, 1999, p. 20. 
O divórcio representa o efeito mais amplo do conflito familiar, pois, não foi possível a manutenção do casal conjugal. Para Jean Carbonnier, o divórcio já está fadado a acontecer, se não houver aceitação social e se

"pelo menos uma das duas famílias desaprovou aquele casamento
(sem dúvida porque se tratava de uma união heterogênea,
desarmônica), a tal ponto que a solução do divórcio, longe de
parecer desvio ou desordem, aparece como o retorno à ordem
superior." 93

Considerando que a obra Flexible droit teve sua primeira edição em 1969, as reflexões acerca das causas do divórcio revelam um pensamento avançado para a época, além de marcadamente pós-moderno, dada a sua visão interdisciplinar. Por intermédio da sociologia jurídica, o autor conseguiu enquadrar o conflito que dá origem ao divórcio no ponto de vista de sua função eugênica:

\begin{abstract}
“(...) ao menos um casal a cada grupo de três ou quatro se dissolve para que os outros se conscientizem do relativo sucesso de seus casamentos, da fragilidade deste sucesso, e do sentimento de precariedade, reforçando a coesão. De sorte que o casal divorciando pode ser sacrificado pela felicidade dos casais nãodivorciandos. Trata-se de uma forma de higiene da sociedade." 94
\end{abstract}

Com uma visão jurídica realista do conflito familiar, Gérard Cornu descreve os efeitos avassaladores do divórcio, numa visão de rejeição social, atento ser cultural a idéia de que as pessoas teriam fracassado no relacionamento, ainda sob o influxo cultural da indissolubilidade do casamento:

\footnotetext{
93 A palavra divórcio, neste contexto, deve ser interpretada amplamente, como ruptura, alcançando, assim, a dissolução da união estável e a separação judicial, posto que não se limita ao conceito técnico-jurídico do instituto.

94 CARBONNIER, Jean. Flexible droit, p. 206.
} 
"Na situação familiar o divórcio muda tudo. A separação dos pais torna impossível que os filhos vivam com o casal parental unido. $\mathrm{O}$ divórcio põe fim à comunidade de vida parental vivida na realidade cotidiana do mesmo lar. Mesmo no exercício conjunto há dois lares. Do divórcio nasce uma família monoparental, se os filhos permanecerem com um dos genitores, ou duas famílias monoparentais, se for organizada uma autoridade parental conjunta. Esta adaptação é colocada pela lei sob a inspiração de uma diretiva fundamental: o divórcio revela que o interesse da criança é um interesse superior à salvaguarda ao qual, na desunião parental, a sociedade é chamada a velar, por se tratar a um interesse exterior aos pais, no sentido de que a criança não lhes pertence como uma coisa a partilhar, como a prataria, nem um ser que está na terra para assumir seus problemas, mas para cumprir seu destino. Esta é a mensagem que, no divórcio, a sociedade dirige aos pais desunidos. Pais, vocês não são nada.",95

Sob a égide da doutrina pós-moderna e norteado pela interdisciplinaridade, o conflito familiar deverá ser regido pelos valores atribuídos por Erik Jayme (pluralismo, comunicação, narração e le retours des sentiments, ou revival). Não cabe mais ao Direito o entendimento do conflito apequenado pela ótica unidisciplinar, positivista e técnica, posto que oriundos de paradigmas ultrapassados. Para esta compreensão rejeitada pela família contemporânea, o conflito é anti-social e necessita de mecanismos jurídicos capazes de resolvê-los, extingui-los, exterminá-los com renúncias mútuas.

O Código de Família brasileiro acolhe o conflito familiar como fenômeno humano, natural, voltado ao direito da personalidade, para ser transformado de acordo com as múltiplas possibilidades existentes - única certeza a ser afirmada pelo paradigma da ciência contemporânea.

95 CORNU, Gérard. Droit civil: la famille. 7. ed. Paris: Éditions Montchrestien, EJA, 2001. 
Conforme mencionado por Antonio Junqueira Azevedo ${ }^{96}$, o paradigma da pósmodernidade não é mais nem a lei nem o juiz, mas sim o caso. Portanto, a construção do Código de Família brasileiro deverá ter essa orientação. Deverá corresponder à tendência de associar direito de família e direito da personalidade, individualizando, assim, a prestação jurisdicional na conformidade da dignidade da pessoa humana.

96 AZEVEDO, Antonio Junqueira. O direito pós-moderno e a codificação. Revista da Faculdade de Direito, Universidade de São Paulo, São Paulo, v. 94, p. 3-11, 1999. p. 5. 


\section{FORMAÇÃO DO DIREITO DE FAMÍLIA BRASILEIRO}

O Código de Família brasileiro corresponderá à identidade cultural que marca a história da formação da família brasileira, que apresenta características muito próprias e intensa miscigenação de raças e culturas. Há direitos de ordens diversas, decorrentes das condições regionais, climáticas etc. No entanto, numa visão pós-moderna, o estudo da historiografia dos institutos visa à possibilidade de co-existência de um Direito de Família democrático, com a manutenção do antigo e do novo, da justaposição, criativamente.

Jean Carbonnier ${ }^{97}$ aponta, com muita propriedade, a intervenção da ciência - em especial, a Medicina, a Biologia e a Genética - na construção do Direito de Família.

O perfil da família brasileira tem peculiaridades devido à sua formação sóciocultural, tendo sido regida pelas Ordenações portuguesas durante séculos, até a conquista do Código Civil de 1916, representando uma codificação avançada e universal, pois, calcada no Código de Napoleão, que serviu de modelo para muitos códigos, e ainda é referência no terceiro milênio.

O modo de regulação jurídica do povo brasileiro marcou o Direito pátrio, com reflexos que ainda estão presentes como preconceitos, embora a legislação já tenha corrigido muitos desvios, a exemplo dos regimes de exclusão e de desigualdade.

97 CARBONNIER, Jean. Droit civil, p. 33. 


\subsection{A DESIGUALDADE ENTRE OS FILHOS}

No século XVIII, no Brasil colonial, não havia acesso ao conhecimento do funcionamento biológico da sexualidade e da reprodução humanas. A gravidez indesejada era muito freqüente, mas nem se pensava na hipótese de procedimentos abortivos para pôr fím à gestação, pois, não existia penicilina e a mortalidade por infecções era alarmante ${ }^{98}$. Tais circunstâncias geraram efeitos de ordem social, psíquica e jurídica.

O primeiro instituto na história dos mecanismos jurídicos de regulação social da família brasileira é a Roda dos Expostos ${ }^{99}$, fundada em 1738, no Rio de Janeiro. Constituía um estabelecimento aparelhado para receber e abrigar crianças que eram rejeitadas devido à condição jurídica em que foram concebidos, ou na ocasião do nascimento. Recebiam a denominação de expostas e enjeitadas, por serem excluídas da moldura legal do quadro de família. Eram, em geral, filhos espúrios, adulterinos, naturais, enfim, era uma filiação excluída, sob pretexto de proteção à família brasileira.

A Roda dos Expostos inaugurou o paradigma da desigualdade entre os filhos, que seria adotado pelo Código Civil de 1916. A ficção da desigualdade entre os filhos - apenas formal, pois biologicamente são iguais - conviveu com o princípio da indissolubilidade do vínculo matrimonial - e patrimonial, por conseqüência e principalmente - sendo este vínculo singular, posto que a norma constitucional descrevia o casamento como única forma de constituição de família.

98 A respeito do assunto, trata o artigo de autoria de Águida Arruda Barbosa intitulado Mulher. Cinco séculos de desenvolvimento na América. Capítulo Brasil, p. 245-287: "Seguramente, são duas as causas do fenômeno. De um lado a desinformação e o desconhecimento de práticas contraceptivas, capítulo inédito no Brasil colonial. Além do que enfrentavam o tabu do sexo e do conhecimento do próprio corpo. De outro lado, a mulher decidida a abortar nem sempre se encorajava a se submeter a tratamentos tão primitivos, que empregavam sanguessugas na vulva, saltos de muro, cavalgadas, múltiplas sangrias aplicadas no mesmo dia, vomitórios provocados por purgativos que continham excrementos entre seus ingredientes, ou preparados de vinho com arruda etc".

99 Conta-se que era regra geral nas noites de profunda calada, na escura constância das quais, se podia enxergar, a custo, vultos se esgueirando. Quem se aproximasse deles reconhecia mulheres, parteiras e curiosas, sob cuja mantilha se abrigavam criancinhas pequeninas. Iam depositá-las na Roda, receosas de serem castigadas. 
A Roda dos Expostos exerceu um papel fundamental na formação da estrutura moral e social da família brasileira, marcada pela história secreta da dor feminina ${ }^{100}$. Era comum encontrar o quadro do abandono de Moisés na decoração de edifícios públicos, com o propósito de sedimentar a imagem de que a tradição cristã tolerava a prática do abandono de crianças como forma paradoxal de amor.

Este comportamento religioso, fervoroso, era a expressão incontida do comportamento imposto às famílias por questões morais, já que o sistema familiar não aceitava outra forma de adequação, marcou a família brasileira, sob o manto da mentira, perdurando esta atitude de esconder a verdade acerca da existência de um filho rejeitado.

Os efeitos deste comportamento da família, regido pelo sistema de exclusão de filhos indesejados, tem efeitos funestos sobre várias gerações, como tão bem se conhece, pela colaboração do Direito de Família contemporâneo, de natureza interdisciplinar, que amplia o conhecimento jurídico pelo conhecimento da psicanálise e da psicologia.

Este sistema de desigualdade entre os filhos vem desde a Roda dos Expostos, na época colonial, até a segunda metade do século XX.

Em tempos de modernidade e positivismo exacerbado, que regeu o Direito de Família justamente por ocasião da promulgação do primeiro Código Civil brasileiro, a verdade era absoluta e sua forma de expressão era a lei, em nome da qual foram empregados muitos mecanismos de regulação social para um certo enquadre legal. Por exemplo, registrava-se um neto como se fosse filho, como forma de acolher, na família, o fruto de uma gravidez de filha solteira, viúva ou adúltera ${ }^{101}$, portanto, rejeitada pela sociedade. Filhos de homem branco com escravas não eram filhos, uma vez que não ofereciam qualquer risco à harmonia familiar. As filhas defloradas que deixavam de ser

${ }^{100}$ VENÂNCIO, Renato Pinto. Maternidade roubada. In: Coordenado pelo autor. História das mulheres no Brasil. São Paulo: Contexto; Unesp, 1997. p. 89: “... dor compartilhada por mulheres que enfrentavam obstáculos intransponíveis ao tentar assumir e sustentar os filhos legítimos ou nascidos fora das fronteiras do casamento".

101 Ademais, os relatos do período colonial revelam que o adultério feminino assombrava os maridos. Tanto é que as Ordenações Filipinas previam que achando o homem casado sua mulher em adultério, licitamente poderá matar assim a ela como o adúltero. 
casadoiras eram as escolhidas para a vida religiosa, podendo, assim, esconder a vergonha que não era delas, mas de toda a família.

Neste contexto histórico, não havia meios para investigar a paternidade de modo seguro. Portanto, o critério para creditar à maternidade certa a conseqüente paternidade, embora incerta, era a prova de que a mulher tinha vida casta e que ela havia se casado virgem. Os avanços científicos para a aferição segura da paternidade veio lentamente, até a descoberta do DNA, como será objeto de exame.

Florisa Verucci indica, como primeiro passo para a mudança deste critério de segregação de filhos, a promulgação da Lei n. 883 de 21 de outubro de 1949:

\begin{abstract}
"assegurando aos filhos de qualquer condição o direito à pensão alimentícia, permitindo que, após o desquite, qualquer dos cônjuges pudesse reconhecer o filho havido fora do casamento, em testamento cerrado e irrevogável. Reconheceu, ainda, o direito à herança, qualquer que fosse a natureza da filiação". ${ }^{102}$
\end{abstract}

Acompanhando as conquistas científicas marcantes para a revolução do Direito de Família, em 1989, implanta-se o teste de DNA para a investigação de paternidade. As pesquisas vinham sendo desenvolvidas há décadas, e revelavam a necessidade de inclusão dos filhos na moldura legal da família, dada a verdade biológica quase absoluta anunciada pela Biologia. Trata-se do dever da verdade, dever de se colocar em conformidade: "le droit saisi par la biologie", como acentua Jean Carbonnier ${ }^{103}$.

A plena perfilhação no Direito de Família brasileiro ocorre com a promulgação da Constituição Federal, de 5 de outubro de 1988, insculpida no artigo 227, § 6": "Os filhos, havidos ou não da relação de casamento, ou por adoção, terão os mesmos direitos e qualificações, proibidas quaisquer designações discriminatórias relativas à filiação”.

${ }^{102}$ VERUCCI, Florisa. Mulher e família na nova Constituição Brasileira. In: TABAK, Fanny; VERUCCI, Florisa (Org.). A dificil igualdade: os direitos da mulher como direitos humanos. Rio de Janeiro: Relume Dumará, 1994. p. 243.

${ }^{103}$ CARBONNIER, Jean. Droit civil, p. 33. 
A regulamentação do mandamento constitucional veio rapidamente, com a promulgação do Estatuto da Criança e do Adolescente, Lei n. 8.069, em 13 de julho de 1990, que contém a perfilhação amplamente descrita, destinando à família natural o conteúdo dos artigos 25 a 27.

Trata-se da recuperação simbólica - posto que satisfaz o imaginário das pessoas que contém permissão cultural de existência da família natural. Esta lei que tem uma elaboração elogiável, de acordo com os ditames da pós-modernidade, é narrativa e plural, abrindo várias possibilidades: reconhecimento pelos pais conjunto ou separadamente, no próprio termo de nascimento, por escritura pública, por testamento ou por outro documento público.

João Baptista Villela expõe, em comentários à nova orientação do ECA:

\begin{abstract}
"Finalmente, registra-se, no apagar das luzes, de 1992, o aparecimento da Lei n. 8.560, de 29 de dezembro daquele ano. Ela contém 10 artigos e é toda voltada para a questão do reconhecimento da paternidade."104
\end{abstract}

A lei comentada por João Baptista Villela foi bastante polêmica, por valorizar sobremodo a paternidade biológica, contendo um certo propósito de redenção das injustiças cometidas com os filhos não-matrimoniais, ao longo da história. A Lei merece certa reprimenda desse autor:

"no seio de uma sociedade que se pretende pluralista e fundada no reconhecimento da autodeterminação pessoal, constitui conduta

104 VILLELA, João Baptista. O reconhecimento da paternidade entre o pós-moderno e o arcaico: primeiras observações sobre a Lei 8.560/1992. Repertório IOB de Jurisprudência, São Paulo, n. 4, fev. 1993. p. 71. 
política inaceitável deferir ao Ministério Público o poder de investigar a paternidade, sem a iniciativa do interessado direto."

\subsection{A DESIGUALDADE ENTRE HOMEM E MULHER}

A família brasileira, conforme já anunciado, foi historicamente marcada pelo princípio geral de desigualdade: entre os filhos e entre homem e mulher. Examinado o eixo da parentalidade, resta enfrentar o eixo da conjugalidade, sob a égide da desigualdade.

Apesar da influência das conquistas do conhecimento científico como diretrizes de transformação do Direito de Família, cuja dinâmica corresponde ao dever de integrá-las às suas disposições normativas, observa-se a marcante trajetória do paradigma da desigualdade de direitos entre homem e mulher, que vigorou até a segunda metade do século XX.

A Igreja Católica exerceu grande influência sobre a manutenção da família, regulando a sexualidade humana, ditando comportamentos. Culturalmente, embora houvesse o dever recíproco de fidelidade entre os cônjuges, acolhido pelo Código Civil de 1916, houve sempre uma permissividade velada ao varão: ao homem, tudo, desde que fora do casamento e com mulheres não casadoiras; à mulher nada, pois, no contexto matrimonial, o sexo visava à procriação e era desprovido de prazer, pois isto era próprio para um perfil de mulher qualificada de desonesta ${ }^{106}$, conceito que sobreviveu até o terceiro milênio.

\footnotetext{
105 VILLELA, João Baptista. O reconhecimento da paternidade entre o pós-moderno e o arcaico, p. 73.

106 "Mulher honesta" foi uma expressão que perdurou até o advento Lei 11.106/2005, que trouxe alteração ao Código Penal, para retirar o termo da norma jurídica. Este termo significava mulher de recato sexual, porque quando havia crime sexual praticado por "mulher desonesta", esta não dispunha de proteção da lei, com franca discriminação. Para completar o pensamento, vale lembrar que "homem honesto" não tem qualquer relação com comportamento sexual, mas era expressão usada para se referir a quem não roubava e pagava suas contas em dia.
} 
Assim, foi contida a força da poderosa sexualidade feminina, e, em contrapartida, foi exaltada a sexualidade masculina e o poder inerente à sua expressão. A mulher foi subjugada ao marido - chefe da sociedade conjugal - e este garantia a proteção do patrimônio da família, administrando-o. O paradigma da desigualdade dos filhos havidos pelo marido em suas relações sexuais extraconjugais tinha o condão de protetor do patrimônio, pois, uma vez excluídos da instituição da família, eles não poderiam compartilhar da fortuna amealhada na constância do matrimônio.

O mecanismo jurídico adotado para adaptar a família brasileira à moldura legal foi o rebaixamento da condição jurídica da mulher casada, que passou a ser relativamente incapaz. Esta prática foi acolhida pelo Código Civil de 1916. A marca desta desigualdade legal foi cunhada com a obrigatoriedade imposta à mulher de adotar o patronímico do marido, a chefia da sociedade conjugal, e a outorga ao varão da administração dos bens do casal. Em relação ao patrimônio, a desigualdade expressou-se na tradição jurídica, no final do século XIX, pelo uso do regime dotal para o casamento, acolhido no Código Civil de 1916, que reservava 31 artigos para regular o instituto.

Evidencia-se o caráter patrimonialista do Direito de Família vigente desde o Brasil colonial até a primeira metade do século XX. A tradição do regime dotal demonstra a segregação da mulher pobre, pois lhe era retirada a oportunidade de contrair casamento com homem de classe social superior à sua, já que não tinha dote. Retomando a expressão de Jean Carbonnier, esta mulher era excluída de determinados bailes: "só vão ao mesmo baile aqueles que já pertenciam, anteriormente, a um meio que os torna predestinados a dançar juntos".

Somente com o advento da pílula anticoncepcional, na década de $1950^{107}$, ocorre um declínio da desigualdade legal entre homem e mulher. Há mudança de comportamento da mulher que, pela primeira vez, tem acesso a contraceptivo seguro, de natureza hormonal, que lhe permite decidir sobre a gravidez. Esta conquista da ciência atribui

${ }^{107} \mathrm{O}$ advento da pílula anticoncepcional coincide com a pós-modernidade, com a liberação sexual das pessoas, permitindo-lhes que exerçam a sexualidade antes do casamento, já que a filiação pode ser planejada. No início da década de 1960 houve um espetáculo teatral marcante, que tratava dessa liberalidade: Hair, na qual um grande elenco se mostrava nu. O musical teve como autoria do texto e direção do espetáculo de James Rado e Jerome Roger. Estreou na Brodway em outubro de 1967. 
qualidade de vida à mulher, com permissão de sexualidade prazerosa, e não mais limitada à procriação, como determinava a Igreja e os bons costumes. Além disso, a mulher torna-se livre para expandir projetos em outras áreas da vida, principalmente no que diz respeito à vida profissional. ${ }^{108}$

Eis o nascimento da família nuclear.

A expressão jurídica da influência do contraceptivo hormonal no Direito de Família foi o advento do Estatuto da Mulher Casada ${ }^{109}$, Lei n. 4.121 promulgada em 27 de agosto de 1962. Esta lei atribuía à mulher o primeiro passo à igualdade, instituindo os bens reservados, que asseguravam a ela, exclusivamente, o fruto de seu trabalho fora do lar, não se relacionando com o regime de bens adotado para o casamento.

O Estatuto devolveu a capacidade plena à mulher casada, ao retirar a restrição de direitos imposta pelo artigo $6^{\circ}$ do Código Civil de 1916, segundo o qual, a mulher rebaixava a sua condição ao se casar, para se equiparar aos menores púberes, aos silvícolas e aos pródigos, ainda que fosse maior de 21 anos - maioridade à época.

O Estatuto da Mulher Casada representou um avanço para o Direito de Família, estagnado desde a promulgação do Código Civil de 1916 e conferiu uma certa igualdade de direitos entre cônjuges. Esse dispositivo só teria sentido se acompanhado pela revogação do principio da chefia, e terminado, por conseqüência, com os privilégios do marido na administração dos bens, no pátrio poder e em outros institutos discriminatórios.

Outra conquista legal importante, logo depois da liberação sexual advinda com a pílula anticoncepcional, foi a do paradigma da possibilidade de dissolução do vínculo

108 JAYME, Erik apud MARQUES, Claudia Lima. Igualdade entre filhos no direito brasileiro atual: direito pós-moderno?, p. 17. "O nascimento ou reconhecimento de novos sujeitos na família inverte o ponto de concentração do direito, da instituição como um todo, para as partes, para os sujeitos individualmente considerados, em um novo pluralismo de sujeitos. Schwab chega a mencionar a família como o "ponto de encontro' de direitos individuais".

109 A Lei dá origem à redação atual do artigo 246 do Código Civil Brasileiro de 1916 instituindo os bens reservados à mulher casada, como mecanismo de ajuste no tratamento da desigualdade entre homem e mulher. Outros artigos do Código Civil foram modificados pelo Estatuto da Mulher Casada, com reflexos em direitos pessoais e patrimoniais, tanto para o homem como para a mulher. 
matrimonial, com o advento da Lei n. 6.515 promulgada em 28 de junho de 1977, que recepcionava o divórcio no ordenamento jurídico brasileiro.

Com a Lei do Divórcio dá-se a inclusão do regime de comunhão parcial de bens como regime legal, estabelecendo regras mais claras para a administração do patrimônio dos cônjuges. Na celebração do casamento, se não fosse declarado expressamente outro regime instrumentalizado em pacto antenupcial, passou a prevalecer o regime da comunhão parcial de bens, no qual os patrimônios somente se confundem se forem adquiridos na constância do casamento, excluídos aqueles provenientes de causa anterior ao casamento, a exemplo de direitos hereditários.

O divórcio traz mecanismos de igualdade entre homem e mulher ${ }^{110}$, desobrigando o cônjuge feminino a adotar o patronímico do marido, porém, se assim ela desejar, por uma questão cultural e de usos e costumes ainda arraigado à família brasileira, poderá acrescentar ao seu o sobrenome do cônjuge, mantendo sua identidade social.

A Lei do Divórcio representa, ainda, um marco importante para transformar o concubinato puro $^{111}$ em união estável, exercendo uma eugenia na família e admitindo a família natural e a institucional como uma só forma de identificação.

Outra oportunidade de refinamento do instituto do divórcio, segundo Florisa Verucci:

${ }^{110}$ A consolidação dessas conquistas teve o seu amplo reconhecimento em 1995, por ocasião da realização da Conferência Mundial da ONU sediada em Beijing, China. A partir de então, os direitos da mulher foram alçados à categoria de direitos humanos, com a recomendação a todos os países participantes que implantassem uma plataforma de ação que pudesse dar prioridade ao combate à feminização da pobreza e à violência contra a mulher, estruturando mecanismos em prol da saúde reprodutiva e os meios de comunicação. Dois neologismos desenvolvem-se a partir desse intercâmbio de movimentos femininos, que expressam a universalidade de conscientização em relação aos direitos da mulher. Com as devidas adaptações ao idioma pátrio: empoderamento e maternagem. O empoderamento da mulher expressa empowerment, do inglês, que não encontra, no português, uma palavra equivalente, com força suficiente para transmitir a idéia contida no termo: oportunidade de participação nas decisões que interferem na qualidade de vida de uma nação. O neologismo maternagem traduz o aspecto social e institucional da maternidade, advinda da capacidade biológica de reprodução humana. Há, assim, o reconhecimento do papel social da mulher, com a clara discriminação ao termo "maternidade", vocábulo reservado para expressar o exercício da subjetividade da mulher em relação à prole natural, adotiva ou advinda pelos meios de reprodução assistida.

111 AZEVEDO, Álvaro Villaça. Do concubinato ao casamento e fato. Belém: Cejup, 1987. p. 32. 
“A Constituição de 1988 promoveu uma verdadeira 'democratização da família' foi além da liberalidade da Lei do Divórcio e reduziu o prazo para o divórcio após a homologação da sentença da separação judicial de três para apenas um ano, acolhendo também a possibilidade de requerer o divórcio direto, sem a separação judicial, se os cônjuges estiverem separados de fato há mais de dois anos. Eliminou a restrição de um único divórcio." 112

\subsection{DA CONSTITUCIONALIZAÇÃO DO DIREITO DE FAMÍLIA AO CÓDIGO CIVIL DE 2002}

Com a promulgação da Constituição Federal de 1988 houve uma revolução no Direito de Família. A Lei Maior do Direito de Família era, até então, o Código Civil de 1916. No entanto, o texto constitucional inaugurou paradigmas que acarretam uma mudança de enfoque e de escala valorativa, passando, então, a ser a Carta Magna de 1988 a Lei Maior a reger o Direito de Família brasileiro.

A Constituição Federal de 1988 inverte o sistema de exclusão de filhos tidos fora do casamento, já amenizado com a paulatina normatividade que foi transformando a rigidez do sistema, flexibilizando o paradigma, para passar ao sistema da inclusão, com a implantação do princípio da igualdade entre todos os filhos, conforme artigo 227 , $\S 6^{\circ}$, da Lei Maior.

Outra mudança paradigmática importante é a adoção da pluralidade de formas de constituição da família, como descreve o artigo 226 da Constituição Federal, acolhendo três modalidades: casamento, união estável entre um homem e uma mulher e a entidade familiar formada por qualquer dos pais e seus descendentes. Trata-se de reflexo da doutrina pós-moderna, promovendo a abertura das relações familiares de modo plural, dando ênfase à individualidade de escolha e à liberdade de expressão, sem preconceitos de qualquer ordem. Ao menos pelo enfoque da lei.

${ }^{112}$ VERUCCI, Florisa. Mulher e família na nova Constituição brasileira, p. 71 
O paradigma mais revolucionário trazido pela Constituição Federal é o princípio da igualdade entre homem e mulher, que recebe dupla menção na Lei Maior:

“artigo $5^{\circ}$, I, homens e mulheres são iguais em direitos e obrigações, nos termos desta Constituição (...)

artigo 226, $\S 5^{\circ}$ Os direitos e deveres referentes à sociedade conjugal são exercidos igualmente pelo homem e pela mulher."

Luiz Edson Fachin ${ }^{113}$ admite que a constitucionalização do Direito de Família é uma resposta às interrogações a propósito de temas polêmicos, decorrentes das novas configurações da família na pós-modernidade.

Nesta mudança valorativa, outorgada pela Constituição ao Direito de Família, deve ser observado que a inversão está em destaque, como destaca Roxana Cardoso Brasileiro Borges:

"é o que se tem chamado de humanização do Direito Civil, personalização do Direito Civil ou repersonalização do Direito Civil. A pessoa é resgatada como valor supremo do ordenamento. A grande tônica do Direito Civil até então, antes da inserção do valor da dignidade da pessoa humana, eram relações patrimoniais. Mesmo as disposições sobre Direito de Família sempre foram muito mais voltadas para as relações econômicas do que para as relações pessoais ou existenciais. A essa alteração se tem chamado de despatrimonialização do Direito Civil, principalmente no Direito de Família." 114

${ }^{113}$ FACHIN, Edson Luiz. Direito de família. Elementos críticos à luz do Novo Código Civil brasileiro. Rio de Janeiro: Renovar 2003. p. 50.

${ }^{114}$ BORGES, Roxana Cardoso Brasileiro. Disponibilidade dos direitos de personalidade e autonomia privada. São Paulo: Saraiva, 2005. p. 82. 
Evidencia-se a ampliação do campo do Direito de Família pela Constituição Federal, pela inserção de princípios, exigindo uma interpretação axiológica. O Direito de Família no Código Civil de 1916 foi perdendo a eficácia, pois estava desconforme com as novas leis e a Constituição de 1988. É no afã da prevalência da Carta Magna sobre o Código Civil de Clóvis Bevilacqua que nasce o Código Civil de Miguel Reale, promulgado em 2002.

Como exalta Francisco Amaral, o Código Civil de 2002 teve uma renovada orientação filosófica, com a influência do pensamento de Miguel Reale, culturalista e antipositivista, que trouxe ao novo código a

“marca da concepção axiológico-experiencial desse jurista-filósofo, com a sua idéia de modelo jurídico, in casu, modelos hermenêuticos que se ligam, direta ou indiretamente, à existência de determinados valores, como o da pessoa humana, o da liberdade, o da igualdade, o da solidariedade, valores esses considerados 'invariantes axiológicas', que fundamentam as diretrizes básicas do Código Civil (a socialidade, a eticicidade e a operabilidade) e influenciam o processo metodológico de sua interpretação." 115

Embora seja um código de orientação principiológica, com cláusulas abertas, centrado na hermenêutica, o Livro IV do Código Civil de 2002 perdeu a oportunidade de acolher a evolução dos institutos de Direito de Família ao longo de sua história. Há, mesmo, involução, relativamente a certos valores que já constituíam conquistas sedimentadas.

Nota-se que, em matéria de família, o Código Civil vigente tem orientação, por ora, claramente positivista, com paradigmas da modernidade, já extintos ou em desuso.

115 AMARAL, Francisco. O Código Civil brasileiro e o problema metodológico de sua realização. Do paradigma da aplicação ao paradigma judicativo-decisório. Revista Brasileira de Direito Comparado, Rio de Janeiro, n. 28, p. 52-79, 2005. 
O Código Civil de 2002 trouxe uma inovação que merece uma análise, para identificar se tem fundamento em paradigma moderno ou pós-moderno.

Trata-se da introdução do regime de bens de participação final nos aqüestos, descrita e prevista nos artigos 1.672 a 1.686 do diploma legal. Imprime ao casamento uma relação patrimonializada, pois o casal deverá passar a vida dando enfoque à contabilidade, já que, conforme previsto no artigo 1.674: "Sobrevindo a dissolução da sociedade conjugal, apurar-se-á o montante dos aqüestos, excluindo-se da soma dos patrimônios próprios". A orientação pós-moderna não conduz o olhar dos cônjuges sobre o patrimônio, mas o tem como decorrência da relação de afeto, pois o olhar deve ser orientado sobre a ética do cuidado, do afeto etc.

Porém, o Código Civil de 2002, por ora, contém dispositivos de alcance pósmoderno, centrado na pessoa e na dignidade humana, a exemplo do artigo 1.511, que elimina o sistema de culpa para a ruptura do casal conjugal no conceito do casamento: "o casamento estabelece comunhão plena de vida, com base na igualdade de direitos e deveres dos cônjuges". A interpretação sistemática deste dispositivo deve atribuir à palavra casamento o sentido de família, dado o princípio da pluralidade familiar inserto na Constituição

É louvável o critério adotado pelo Código Civil de 2002, ao dividir o Livro IV disposições de Direito de Família - apresentando, no Título I, as disposições de direito pessoal e, no Título II, as disposições de direito patrimonial. Há, nesta discriminação, o reconhecimento dos diferentes níveis desenvolvidos na família, abrindo espaço para reflexões de ordem objetiva e de ordem subjetiva, afinal, há o reconhecimento legal de que a família comporta uma gama inesgotável de relações.

Em 4 de janeiro de 2007, passa a viger a Lei n. 11.441, que inova o Direito de Família com um procedimento extrajudicial consensual para separação, divórcio e partilha inter vivos e causa mortis. Esta legislação sinaliza a influência da doutrina pós-moderna, pois devolve ao jurisdicionado e ao cidadão uma autonomia para acesso à justiça, sem a intervenção paternalista do Estado. Nesse sentido, aponta Luiz Roberto Barroso: 
"Uma das teses fundamentais do pensamento crítico é a admissão de que o Direito possa não estar integralmente contido na lei, tendo condição de existir independentemente da bênção estatal, da positivação, do reconhecimento expresso pela estrutura de poder. $\mathrm{O}$ intérprete deve buscar a justiça, ainda quando não a encontre na lei." 116

Fundamenta, o mesmo autor, a tendência pós-moderna, a orientar a nova lei em exame, a lição de Antonio Junqueira Azevedo ${ }^{117}$ :

"Para cumprir seu papel (o Direito), não há necessidade de, sempre, tudo levar ao juiz; este pode não ser o melhor caminho. Aos poucos os grupos sociais descobrem outras soluções. Da fuga para o juiz (paradigma já ultrapassado) cabe hoje falar em fuga do juiz - e isto, diga-se, não diminui o Poder Judiciário, eis que este fica limitado a agir nas hipóteses em que, de fato, é necessário como julgador. (...) O paradigma jurídico, portanto, que passara da lei ao juiz, está mudando, do juiz ao caso. A centralidade do caso é este: o eixo em torno do qual gira o paradigma jurídico pós-moderno."118

${ }^{16}$ BARROSO, Luiz Roberto. A nova interpretação constitucional, p. 14

17 AZEVEDO, Antonio Junqueira. O direito pós-moderno e a codificação, cit.

118 Esta modalidade de dizer o Direito, com o empoderamento notarial, ampliando-lhe funções, em atitude de pluralismo, contém, também uma abertura para a mediação familiar, apta a colaborar com os divorciandos para garantir uma comunicação adequada para as escolhas necessárias. A mediação será objeto de explanação na Parte II, com capítulo exclusivo. CARBONNIER, Jean. Sociologie juridique, p. 147: “Já era a pós-modernidade, (...) A mesma ambigüidade paira sobre a mediação, esta filha putativa da pósmodernidade moderna: de esquerda, porque justiça popular; de direita, porque um juiz de Estado poderia ser, para os fracos, um protetor". 


\section{CODIFICAÇÃO EM DIREITO DE FAMÍLIA}

O capítulo 1, intitulado "Por que um Código de Família?" já abordou, genericamente, a necessidade de se atualizar o Código Civil em codificação especial, atendo aos paradigmas e princípios da pós-modernidade.

Para tratar dos fundamentos teóricos e práticos do Código de Família brasileiro, este capítulo aborda a codificação em Direito de Família apresentando as experiências da França (que tem um Código de Família) e da Argélia (ainda que este exemplo seja distante da realidade ocidental).

Ficará demonstrado, enfim, que não há nenhuma experiência estrangeira na elaboração de uma legislação especializada, nos moldes ora propostos, de construção de um código de natureza interdisciplinar, orientado pelos paradigmas da pós-modernidade.

\subsection{A EXPERIÊNCIA FRANCESA}

A experiência francesa em Código de Família não traz nenhuma contribuição para a releitura do Direito de Família nos tempos pós-modernos. As experiências da França estão muito mais voltadas para o papel social da família do que para os papéis intrínsecos de seus membros, orientados a uma condição de garantia do livre desenvolvimento da personalidade - matéria inserta nos direitos da personalidade, no Código Civil de 1804. 
A análise do Código de Família francês não pretende ter conotação histórica acerca de codificação especializada para as relações familiares, mas apenas recontar o processo de construção dessa codificação, para extrair dessa experiência alguns parâmetros úteis na elaboração do Código de Família brasileiro.

Em $1939^{119}$, entre a primeira e a segunda guerra, foi elaborado o primeiro Código da Família e da Natalidade Francesa. Em 1956, este código foi atualizado para agrupar todas as matérias ditas familiares, sem uma organização técnico-legislativa especializada para a elaboração de um conjunto de normas orientado por um sentido, intitulado Código de Família e da Ajuda Social da França. O objetivo principal era, como o nome indicava, que ele fosse um código de ação social.

Embora seja antigo, esse Código de Família é também pouco conhecido na França, porque nunca foi agregado ao Direito, e se tornou, como era o objetivo, muito mais um código de ação social. Tanto é assim, que textos declarados fundadores desse código apresentam conteúdo relacionado à saúde e à ação social, mas não discorrem sobre direitos relativos aos membros da família, às funções e papéis a eles inerentes.

No Código de Família e da Ajuda Social da França, existem disposições concernentes à ação pública dos membros da família e às famílias, enquanto organizadas em associações. É esta a principal referência familiar, ou pelo menos a mais visível nessa codificação. Entretanto, a finalidade familial, qual seja, do papel grupal da família e não do papel individual de cada um de seus membros, é igualmente presente, com artigos dedicados à ajuda social e à infância.

É preciso frisar que a definição de família não aparece no Código de 1939, nem no Código de 1956 e nem mesmo no Código Civil, no que concerne às normas de Direito de Família. Todos os códigos apóiam-se no Código Civil, mas não se reduzem ao Direito Privado da Família, ficando apenas na ação social em prol desta, numa relação de Direito Público da Família, mais explícita no Código de 1956. Pode-se dizer que o essencial deste

119 CHAUVIÈRE, Michel; BUSSAT, Virgine. Famille et codification. Paris: La Documentation Française, 2000. Trata-se de uma obra que tem por objetivo analisar as etapas pelas quais passou o Código de Família e da Ação Social da França, de conteúdo familial, como estratégias e política públicas, ao longo das últimas décadas na França. 
código é a referência de direito social, mais precisamente de direito de ajuda e de ação social, direta ou indiretamente, orientado em prol das famílias, em oposição ao Código de 1939, que continha regras de direito fiscal relativas à família.

Observa-se, enfim, que o conteúdo desses códigos não é de Direito de Família, mas, sim, de direito familial, que não visa a uma elaboração jurídica, mas à valorização política de um conjunto legislativo de proteção da família.

Do ponto de vista técnico-jurídico são códigos da categoria de ação pública, tendo por conteúdo a assistência à família, a higiene, a natalidade etc. Portanto, a categoria axiológica a que pertencem esses códigos não é, efetivamente, de família. Estas escolhas teóricas determinam uma sociologia jurídica da família e uma sociologia política familial. Enfim, um código com orientação dessa natureza intervencionista de políticas públicas não é um código, do ponto de vista técnico, mas um simples corpo orgânico de normas.

Em 1956, com a implementação da Previdência Social, a ajuda social torna-se subsidiária, convertendo-se implicitamente em uma questão familial conduzindo politicamente as idéias do código (tal como em outro momento fora orientado para a saúde pública etc.). O período correspondia, portanto, ao momento político familial de legitimação necessária para a criação normativa.

À diferença dos grandes códigos, cujas revisões são objeto de debates em comissões especializadas, acompanhadas pela imprensa e por observadores, os códigos, como este em questão, são desconsiderados, às vezes até ignorados, como os de 1939 e 1956, tidos como subcódigos ou, ainda, resíduos de códigos.

A literatura francesa especializada em Direito não se refere a estes textos tidos como menores. Muitas vezes, a própria existência deles é esquecida, a exemplo de uma alusão ao Código da Família num prefácio redigido por Jean Carbonnier, que, ironicamente comenta: “(...) nosso dito Código da Família muito significativamente intitulado agora Código da Família e da Ajuda Social (...)”. ${ }^{120}$

${ }^{120}$ CHAUVIÈRE, Michel; BUSSAT, Virgine. Famille et codification, p. 16. 
Guy Braibant assina um artigo intitulado "Codification", fazendo comentários à legislação de 1936, enfatiza o momento histórico em que foi promulgada, admitindo que o conteúdo não correspondia à tecnicidade de um código, mas necessitava da visibilidade de um grande código, num momento pós-guerra, em que o Estado tinha interesse em demonstrar cuidado com as famílias:

\begin{abstract}
“(...) entre as duas guerras mundiais a França conheceu um florescimento de códigos diversos por sua natureza, por sua dimensão e por seu valor jurídico, sem que nenhum mereça, verdadeiramente, esse nome. Alguns eram somente novos textos chamados de códigos para lhes dar uma grande solenidade, sob a forma de decreto-lei, como no caso do Código de Família de 1936." 121
\end{abstract}

A experiência francesa, ainda que antiga (posto que tem um Código de Família desde 1936), não serve de parâmetro para a construção do Código de Família brasileiro, pois este deve ser orientado por uma doutrina pós-moderna, com abordagem interdisciplinar, para aprimorar a regulação legal das relações de família existentes no Código Civil brasileiro. Deve haver, no caso brasileiro, uma ampliação das dimensões existentes, que acarrete, conseqüentemente, o deslocamento do conjunto de normas insertas na codificação brasileira de 2002.

Ainda em relação à experiência francesa, como bem acentua Jean Carbonnier um doutrinador pós-moderno por excelência - ao se referir ao diploma legal da França, desqualificando-o, claramente, ao caracterizá-lo como "dito Código da Família", pois seu conteúdo não é o de um código, mas, sim, uma consolidação de matérias que dizem respeito à família. Ademais, há vários registros do sentido familial em lugar de familiar, ou seja, a função social da família, das garantias políticas de sua sustentação e de seu fortalecimento, enquanto tecido social formador do Estado. Tanto é que o doutrinador

${ }^{121}$ CHAUVIÈRE, Michel; BUSSAT, Virgine. Famille et codification, p. 16. 
acentua, na seqüência: "muito significativamente intitulado agora Código da Família e da Ajuda Social".

Em síntese, a França não tem um Código de Família do ponto de vista técnicojurídico, mas um instrumento de ajuda social, subordinado ao Código Civil que, conforme já exposto, não tem um livro dedicado à família. Nele, as normas são organizadas como direitos da pessoa, e as relações patrimoniais entre os cônjuges estão reguladas no título "Diferentes maneiras de adquirir a propriedade", que dedica um subtítulo para regime de bens no casamento.

É preciso contextualizar tais reflexões pela ótica da escala axiológica da cultura francesa. A pessoa está em primeiro lugar e, para protegê-la em sua inteireza, o Estado dá enorme valor à ação social, que visa à ajuda das pessoas - individualmente ou agregadas em famílias. Para finalizar a descrição cultural da ação social associada à família, basta observar que a organização do Estado atribui o tema à pasta: "Ministère de la Santé, de la Famille et des Personnes Handicapées" (Ministério da Saúde, da Família e das Pessoas Deficientes).

Conclui-se, assim, que a ação social é o valor predominante. Este, por sua vez, é o somatório das matérias relativas à saúde, à família e aos deficientes. A experiência francesa é, portanto, particularíssima, e não se presta a exemplo para a construção do Código de Família brasileiro.

\subsection{OUTRAS EXPERIÊNCIAS ESTRANGEIRAS}

Em 1995, na França, uma equipe pluridisciplinar ${ }^{122}$ foi encarregada de proceder a um levantamento criterioso acerca das fontes existentes sobre Código de Família, para uma análise comparativa de sistemas, para agregar o resultado à experiência francesa. Os resultados foram extremamente insuficientes, quase infrutíferos.

${ }^{122}$ CHAUVIÈRE, Michel; BUSSAT, Virgine. Famille et codification, p. 19. 
Na Europa existiu, na União Soviética, um Código de Família, extinto com a dissolução do bloco socialista. Na mídia especializada, não há informações disponíveis a respeito deste código, porque não correspondia a uma produção doutrinária, mas a um instrumento de poder do Estado ${ }^{123}$.

Levantou-se, também, que em alguns países mulçumanos existem códigos especializados. Na Argélia, por exemplo, o Código de Família ${ }^{124}$ foi promulgado em 1984, com forte campanha contra a sua adoção por parte dos movimentos feministas; afinal, há uma incoerência entre a vida pública destas mulheres, que estudaram e exercem profisssões importantes no contexto globalizado, porém, sofrem sérias restrições na vida privada. Trata-se de um código de inspiração religiosa - mulçumana fundamentalista -, que outorga à mulher uma condição jurídica de inferioridade, com atribuição da chefia da família ao homem. Há ainda a previsão de divórcio e o princípio geral da poligamia masculina.

O Direito mulçumano caracteriza-se por se afastar de uma codificação universal, apegando-se aos valores da religião. Trata-se de um direito costumeiro arraigado às origens tribais. A comunidade religiosa veio substituir a tribo e o chefe desta comunidade estabelece as regras de acordo com as revelações do Corão ${ }^{125}$. Pode-se dizer que o Corão representa um código jurídico, como princípio a reger o comportamento social, cultural, religioso, familiar etc. Assim, o Código de Família Argelino é a expressão desta forte influência valorativa.

Tais informações são suficientes para afastar a importância desta experiência estrangeira, posto que seu modelo já foi ultrapassado pelas conquistas do Direito de Família brasileiro.

${ }^{123}$ Em pesquisa na internet há poucas referências a códigos de família, a exemplo do www.yahoo.fr, no qual não se encontra nenhuma referência sobre o Código de Família e da Ação Social, embora seja um sítio dirigido para povos de língua francesa. Enfim, o assunto é escasso. No caso da União Soviética, a Ministra da Justiça, em 1990, Nina Cerkevia não teve autorização para participar de um colóquio de Direito de Família promovido pela Fédération Internationale des Femmes des Carrières Juridiques, realizado em Israel, em maio de 1990, por questões de política internacional. No entanto, em 1992 participou de uma programação semelhante na Bulgária.

124 Os comentários ao Código de Família da Argélia são encontrados no site $<\mathrm{http}: / /$ www.famalgerienne.free.fr $>$. Acesso em: 14 jan. 2007.

${ }^{125}$ SOURDEL, Dominique. Droit musulmant et codification. Droits, Revue Française de Théorie, de Philosophie et de Culture Juridiques, Paris, 1997, p. 33. 
Há outros tantos códigos que poderiam ser relacionados aqui, mas nenhuma contribuição poderia ser agregada à construção de um Código de Família brasileiro, orientado por uma doutrina pós-moderna, conforme já exposto.

Enfim, no cenário jurídico internacional, não há uma iniciativa voltada à fundamentação de um Código de Família de natureza interdisciplinar, com forte ampliação do conhecimento voltado à humanização do Direito de Família, regido por paradigmas da pós-modernidade, com ênfase em principiologia valorativa dos direitos da personalidade.

\subsection{CONCEITO DE CODIFICAÇÃO}

O conceito de codificação e, conseqüentemente, de código, tem aqui o objetivo de esclarecer e justificar a escolha deste instrumento legislativo para acolher a organização sistêmica de todas as relações de Direito de Família no Brasil. Portanto, não cabe traçar a evolução histórica das codificações, nem mesmo as diversas teorias sobre o tema de codificar, recodificar ou descodificar. Trata-se de organizar o conhecimento para introduzir a construção dos fundamentos do Código e Família brasileiro.

Para o Estatuto da Criança e do Adolescente foi afastada a forma codificada, porque atendia a uma orientação internacional inovadora, relacionada à responsabilidade parental, decorrente da Convenção da ONU de 1989.

Como no Brasil havia antes o Código de Menores, e a moderna visão a partir da convenção, que, em vez de filho menor, o termo correto passou a ser criança e adolescente, a legislação especializada foi feita em forma de estatuto, para registrar que não havia sucessão entre um diploma e outro.

Para a elaboração de um Código de Família brasileiro, é preciso compreender em que consiste um código contemporâneo e porque se codifica. Segundo Vicente Marotta Rangel, o conceito de codificação consiste 
"na conversão, em um corpo sistemático de regras escritas, das normas vigentes com pertinência a determinada matéria ou determinada relação. Tais normas, ainda que em vigor, nem sempre são escritas como ocorre, verbi gratia, com as de natureza consuetudinária." 126

O processo de codificação traduz-se em ordenar, sistematicamente, a unidade essencial de um ramo do Direito, organizado numa seqüência de capítulos e artigos, constituídos pelos valores insertos na Constituição, que dão sentido à Lei Magna. Se não houver uma ordenação sistêmica, em lugar de código haverá uma consolidação de matérias inerentes a determinado ramo do Direito. Conforme Gérard Cornu, um código é:

“corpo coerente de textos, englobando, segundo um plano sistêmico, o conjunto de regras relativas a uma matéria, e proveniente seja de trabalhos legislativos (Código Civil), seja de uma elaboração de regulamentação (Código de Processo Civil), seja de uma codificação formal (por decreto). O Código Civil tem vocação para reger seja o conjunto das matérias de Direito Civil, aí compreendido família e obrigações (concepção francesa), (...) à exceção do Direito Familial, conteúdo do Código de Família (legislação socialista)". ${ }^{127}$

A tradição dos grandes códigos é herança da modernidade, do positivismo em busca de segurança jurídica. Tanto é que, etimologicamente, código e codificação derivam de codex, que significa livro compacto, de capa dura, cujo conteúdo é jurídico, com leis e normas reguladoras de um determinado assunto.

Francisco Amaral analisa a função da codificação para o momento histórico do nascimento do Código Civil brasileiro:

\footnotetext{
${ }^{126}$ RANGEL, Vicente Marotta. Codificação do direito espacial. Revista Brasileira de Direito Aeroespacial, Rio de Janeiro, v. 67, set. 1995. p. 2.

127 CORNU, Gérard. Vocabulaire juridique. Vendôme: PUF, 2001. p. 155.
} 


\begin{abstract}
"A concepção atualmente dominante no pensamento jurídico é a do sistema como conjunto aberto e dinâmico que continuamente se enriquece e se constitui, sendo que, para alguns cultores da teoria pós-moderna e pós-positivista do Direito, o sistema não se apresentaria mais como uma estrutura lógico-dedutiva, mas como uma estrutura em rede, em que o movimento do sistema não seria ascendente ou descendente, mas circular, pressupondo não mais a relação de conseqüência, de causa e efeito, mas de inter-relação entre os seus elementos, caracterizando o chamado sistema hermenêutico. Isso implica também na retomada da razão prática, na medida em que o sistema axiomático usa a razão teórica." 128
\end{abstract}

O Código de Família Brasileiro atende a este modelo circular, aberto, de sistema hermenêutico, escrito de maneira que privilegie a narrativa, a exemplo do Estatuto da Criança e do Adolescente, com a exaltação principiológica, que tem a pessoa humana como valor maior e a vida como a concretização e expressão deste direito a ser protegido. Trata-se de um código para o futuro, para um mundo em mudanças constantes, marcado pela universalidade.

Por que um código? Porque se trata de um Direito de Família pós-moderno, que privilegia o antigo para colocá-lo em justaposição ao novo. Não há ruptura. Há desconstrução para a reconstrução, narrada com sentimento - revival ou retours des sentiments - com pluralismo de fontes e comunicação.

\title{
6.4 CODIFICAÇÃO NA PÓS-MODERNIDADE
}

Depreende-se, do reduzido panorama internacional, que não há experiências recentes sobre a elaboração de um Código de Família pós-moderno. No entanto, a idéia tem apoio, a exemplo de Antonio Junqueira Azevedo: "para codificar, hoje, pelo menos

128 AMARAL, Francisco. A decodificação do direito civil brasileiro. Direito e Justiça, Revista da Faculdade de Direito da Universidade Católica Portuguesa, Lisboa, v. XIII, t. 1, 1999. 
duas diretrizes fundamentais devem ser seguidas". Merece destaque seu enfático posicionamento a respeito de codificações unicistas:

“Em primeiro lugar, nada de um código; são necessários vários - é, aliás, o que, na prática, está a acontecer no mundo todo (trata-se de conseqüência da hipercomplexidade e da desistência da tentativa de reduzir tudo à unidade). Para o Direito Civil, deveria haver um código das obrigações, precedido e parte geral, e mais, no mínimo, um Código de Família, Código do meio-ambiente e dos direitos reais, um Código dos Direitos da Personalidade e um Código de Direitos das Sucessões, além, naturalmente, de leis especiais (locação, criança e adolescente, minas, etc.). Somente este fracionamento permitiria - e esta é a segunda diretriz fundamental - a participação popular efetiva na elaboração da lei (tem de haver a interação)."129

Roxana Cardoso Brasileiro Borges oferece importante fundamento à idéia de descentralização do Direito Civil, em face das alterações sociais, econômicas e culturais, devido à necessidade constante de regulação de novos fatos e novas realidades:

"a saída que se encontrou para melhor disciplina e certos institutos foi a legislação especial e a elaboração de novos 'microcódigos' ou 'microestatutos' ou 'microornenamentos' voltados para temas mais particulares. O Código Civil Brasileiro foi perdendo, assim, sua posição central no Direito Civil. Sua posição de 'Constituição do Direito Privado' que pretendia regular todos os aspectos da vida civil dos indivíduos foi abalada por diversas leis, estatutos e microssistemas que surgiram ao longo do século XX."130

129 AZEVEDO, Antonio Junqueira. O direito pós-moderno e a codificação. Revista da Faculdade de Direito, Universidade de São Paulo, São Paulo, v. 94, 1999. p. 10.

130 BORGES, Roxana Cardoso Brasileiro. Disponibilidade dos direitos de personalidade e autonomia privada, p. 84 . 
Portanto, evidencia-se a tendência pós-moderna de desconstruir e, conseqüentemente, descodificar, para recodificar de acordo com a orientação paradigmática contemporânea. E este resultado já se sentiu na constitucionalização do Direito Civil, com ênfase no Direito de Família, como já exposto.

A experiência francesa na elaboração de um Código de Família não acompanha esta tendência, pois - reafirme-se - ele não corresponde tecnicamente a um código, sendo importante tão-somente para a consolidação das diversas leis que tratam da família, mas visando sempre à ação social. Logo, não se trata, verdadeiramente, de um Código de Família, mas de um código familial - ou seja, de acordo com as políticas públicas. Não há qualquer pretensão de retirar a regulação das relações familiares do Código Civil de 1804 para aperfeiçoá-la com a organização de outro sistema. E isto se deve ao fato já mencionado de que nas comemorações do bicentenário do Código de Napoleão houve uma ratificação tácita de continuidade do sistema para mais um século.

Bem salienta Roxana Cardoso Brasileiro Borges no tocante ao sentido de recodificar o Direito Civil em microssistemas:

"não se trata, na verdade, de ser ou não época de codificação do Direito Civil. A questão para a qual se deve voltar é o conteúdo trazido pela nova codificação. A esta altura parece sem utilidade a discussão sobre se a matéria deveria ser regulada sob a forma de legislação esparsa ou de Código(...). Essa é a verdadeira questão: se a regulamentação proposta (independente de ser em forma de lei extravagante ou de Código) tem o conteúdo de que a sociedade necessita no momento."131

O Código de Família brasileiro deverá corresponder à necessidade premente da pessoa humana, titular de direitos fundamentais orientados pelo axioma da dignidade, que é maculada cotidianamente por um Direito impessoal para regular as relações de família e pela falta de humanização dos meios de acesso à justiça.

131 BORGES, Roxana Cardoso Brasileiro. Disponibilidade dos direitos de personalidade e autonomia privada, p. 88 . 
O Código de Família brasileiro enfrenta a seguinte questão: qual é a lei ideal para regular as relações familiares? Jean Carbonnier responde com propriedade a essa indagação:

\begin{abstract}
“como a família pertence aos costumes, em grande parte, uma legislação da família é possível e pode mesmo ser eficaz dentro de certos limites. Por pouco que esta legislação corresponda a um desenho de conjunto, a uma imagem que o legislador terá como família ideal, ter-se-á que falar de uma política legislativa da família (...). A legislação da família não é inútil. Mas, ela é difícil de ser executada. O obstáculo decorre do fato de que os fatos de família são quotidianos." 132
\end{abstract}

Depreende-se que a peculiar legislação atinente à família deve corresponder a uma reflexão filosófica, sociológica, psicanalítica, antropológica etc. Portanto, a natureza interdisciplinar é essencial para a construção dos fundamentos teóricos e práticos do Código de Família brasileiro.

A questão sobre o método a ser adotado para legislar sobre a família, tendo como orientação os princípios da doutrina pós-moderna, é a de responder se é útil a elaboração do Código de Família brasileiro. A resposta vem das reflexões de Antonio Junqueira Azevedo:

“As considerações sobre o que seja, ou não, verdadeiro são, na pósmodernidade, deixadas de lado e substituídas pelas sobre o que seja, ou não, útil (neopragmatismo). São de Rorty (1988) as afirmações a seguir: 'Nós não temos idéia, na frase 'a realidade é como ela é, em si mesma' sobre o que este 'em si mesma' supõe. Nós sugerimos (pois), o abandono da distinção 'aparência/realidade' em favor da distinção 'mais útil/menos útil'

132 CARBONNIER, Jean. Flexible droit, p. 222-223. 
como forma de pensar (...) Nossos críticos, (porém), não acreditam que a distinção 'mais útil/menos útil' possa tomar o lugar da velha distinção 'aparência/realidade'. No campo do Direito a consideração da 'realidade como ela é' parece ao jurista pressuposto básico para a muito procurada segurança jurídica; a simples dúvida sobre a aptidão de o pensamento refletir a realidade incomoda." 133

O pensamento pós-moderno representa a mudança de paradigma, invertendo o modo de pensar como bem acentua Antonio Junqueira de Azevedo:

“(...) na primeira metade do século XX, o paradigma era a lei rígida, inflexível, alheia às diversidades da vida - com garantia de impessoalidade, decorrente do trauma do absolutismo; houve mudança de paradigma, passando a ser como centro a figura do juiz (representante do Estado), com as cláusulas gerais, para que o juiz preenchesse com o direito; e, por último, o paradigma da pósmodernidade é o caso, porque centrado na valoração da vida, em geral, e da vida e da dignidade da pessoa humana, em particular" ${ }^{\prime 34}$.

A valoração da vida concretiza-se na ética do cuidado, desde antes do nascimento com vida, na proteção da dignidade da pessoa humana. João Baptista Villela narra com sentimento a atividade do cuidado para preservar a dignidade humana, objeto do próximo capítulo:

“As relações de família, formais ou informais, indígenas ou
exóticas, ontem como hoje, por muito complexas que se
apresentem, nutrem-se todas elas, de substâncias triviais e
ilimitadamente disponíveis a quem elas queiram tomar: afeto,

AZEVEDO, Antonio Junqueira. O direito pós-moderno e a codificação, p. 4.

134 AZEVEDO, Antonio Junqueira. O direito pós-moderno e a codificação, p. 6. 
perdão, solidariedade, paciência, devotamento, transigência, enfim, tudo aquilo que, de um modo ou de outro, possa ser reconduzido à arte e à virtude do viver em comum. A teoria e a prática das instituições de família dependem, em última análise, de nossa competência em dar e receber amor". ${ }^{135}$

135 VILLELA, João Baptista. As novas relações de família. Anais da Conferência Nacional da OAB. Foz do Iguaçu, set. 1994. p. 645. 


\title{
FUNDAMENTOS TEÓRICOS DO CÓDIGO \\ DE FAMÍLIA BRASILEIRO
}

\subsection{CRITÉRIO DE ESCOLHA DOS FUNDAMENTOS}

João Baptista Villela descreve, com assertividade, a atividade jurisdicional do Estado para os conflitos de família:

\begin{abstract}
"Não se pretende que o direito de família se substitua à psicoterapia, mas seria redução imperdoável de suas virtualidades concebê-lo ou praticá-lo com exclusão do aconselhamento preventivo e reparatório, assim como da mediação extrajudicial". ${ }^{136}$
\end{abstract}

Esta frase lapidar descreve claramente a utilidade do Direito de Família e constitui um verdadeiro eixo condutor de organização da atividade jurisdicional, aplicável ao Código de Família Brasileiro, posto que norteado pelo pensamento da doutrina pósmoderna.

O Código de Família brasileiro tem, em sua essência, o sentido voltado para este valor pós-moderno: em prol do desenvolvimento da personalidade por intermédio das relações humanas. A atividade jurisdicional é agente do aconselhamento preventivo $e$ reparatório capaz de devolver ao jurisdicionado o importante registro a ser feito, extraído

136 VILLELA, João Baptista. Repensando o direito de família. In: Anais do primeiro Congresso Brasileiro de Direito de Família promovido pelo Instituto Brasileiro de Direito de Família. Belo Horizonte: Del Rey, 1999. p. 20. 
da análise dos ciclos vitais da família: as funções, no sistema familiar, mudam de posição, quando os membros da família assumem novas funções.

Outro registro importante a ser feito é que as crises de transição de um ciclo para outro são naturais, o que muito alivia não só aqueles que sofrem como sujeitos de direito, mas também os profissionais, que trabalham com o sofrimento humano. No entanto, se as crises de transição não forem adequadamente conduzidas, ou não forem oportunamente identificadas pelos membros da família, acumular-se-ão à crise seguinte, dando-lhe uma magnitude, às vezes, intransponível.

Este pode ser um ponto de muita vulnerabilidade da família, podendo aparecer os sintomas, quase sempre na forma de litígio, o que pode acarretar a ruptura do casal conjugal. Como o Judiciário não está aparelhado para enfrentar o litígio pelo enfoque interdisciplinar - um conhecimento que amplia as disciplinas em sua extrema especialidade, paradigma da pós-modernidade em lugar de paradigma da modernidade - a demanda judicial pode contribuir negativamente, tornando o conflito crônico, pois entregue à vontade da lei externa, e não à lei interna de constituição psíquica. Em síntese, há uma paralisação da evolução natural de uma família.

A concretização desse eixo é possível desde que conforme os quatro valores descritos por Erick Jayme ${ }^{137}$, que deverão estar sempre presentes na interpretação das normas e na metodologia de aplicação dos princípios e dispositivos legais do Código de Família brasileiro:

a) pluralismo - na linguagem do direito, pluralismo significa ter à disposição alternativas, opções, possibilidades;

b) comunicação - associado à valorização extrema do tempo, do direito como instrumento de comunicação, de informação; é a valorização de passar o tempo nas relações humanas, valorização do eterno e do transitório, do congelar momentos e ações para garantir a proteção dos mais fracos e dos grupos que a lei quer privilegiar;

137 JAYME, Erick. Vide capítulo 2, Direito de Família Pós-Moderno, subtítulo 2.2, Valores pós-modernos, em que já foi tratado este tema com maior amplitude, cabendo neste capítulo apenas arrolar os quatro valores pós-modernos. 
c) narração - decorrente do impulso de comunicação, de informação, que invade a filosofia do direito e as próprias normas legais; narrativa do efeito útil, do sentido, dos princípios, das finalidades, possibilitando uma interpretação teleológica; narrativa da alegria de viver;

d) retour des sentiments - ou revival dos direitos humanos, concretizado em permissividade de uma certa emocionalidade no discurso jurídico.

A atividade jurisdicional, que pressupõe formação especializada e evidente vocação para atuar com família e sofrimento humano, será regida pelo paradigma da ética do cuidado.

\section{2 ÉTICA DO CUIDADO}

Os recentes estudos sobre a ética do cuidado ${ }^{138}$ são decorrentes do pensamento pós-moderno, representando, entre outras características, o retour des sentiments, que se traduz em resgate da capacidade humana de se emocionar e de ter sentimentos, reações que passam a merecer valoração jurídica.

A ética do cuidado afasta-se, por completo, da idéia de estratégias meramente assistencialistas e paternalistas. Para uma reflexão acerca dela, deve-se recusar a idéia de sinonímia entre as palavras ajuda e cuidado. Isso porque o termo ajuda perpetua a dependência, humilhando o ser humano, justificando-se apenas para situações claras de nível de superioridade de um ser sobre o outro. Já a palavra cuidado visa à independência e à libertação do ser pelo reconhecimento de sua força de transformação da sociedade, que atinge o $e u$.

${ }^{138}$ SILVEIRA BUENO, Francisco da. Grande dicionário etimológico-prosódico da língua portuguesa, 2 v., p. 862: "cuidar - v. t. e rel. Pensar, julgar,imaginar, ter pensão de alguém, tomar conta dele. Lat. cogitari".O vocábulo "Pensar" (ob. cit., 6 v., p. 2.957) "tomou o significado de curar, tomar conta. Por exemplo, como preocupação de um dos pais para com os filhos, pensão tem sentido de albergue e alimentação". 
A compreensão do sentimento e da razão da ética do cuidado passa pela imagética da Fábula de Higino ${ }^{139}$ :

"Certo dia, ao atravessar um rio, Cuidado viu um pedaço de barro. Logo teve uma idéia inspirada. Tomou um pouco do barro e começou a dar-lhe forma. Enquanto contemplava o que havia feito, apareceu Júpiter. Cuidado pediu-lhe que soprasse espírito nele. $\mathrm{O}$ que Júpiter fez de bom grado. Quando, porém, Cuidado quis dar um nome à criatura que havia moldado, Júpiter o proibiu. Exigiu que fosse imposto o seu nome. Enquanto Júpiter e o Cuidado discutiam, surgiu, de repente, a Terra. Quis também ela conferir o seu nome à criatura, pois fora feita de barro, material do corpo da Terra. Originou-se então uma discussão generalizada.

De comum acordo pediram a Saturno que funcionasse como árbitro. Este tomou a seguinte decisão que pareceu justa: Você, Júpiter, deu-lhe o espírito; receberá, pois, de volta este espírito por ocasião da morte dessa criatura.

Você, Terra, deu-lhe o corpo; receberá, portanto, também de volta o seu corpo quando essa criatura morrer.

Mas como você, Cuidado, foi quem, por primeiro, moldou a criatura, ficará sob seus cuidados enquanto ela viver.

E uma vez que entre vocês há acalorada discussão acerca do nome, decido eu: esta criatura será chamada Homem, isto é, feita de húmus, que significa terra fértil”.

${ }^{139}$ A Fábula de Higino - sobre o cuidado essencial - é de origem latina, mas tem base grega. Ela ganhou sua versão literária definitiva pouco antes de Cristo, em Roma. A versão em português aqui citada está publicada na obra de Leonardo Boff: Saber cuidar - Ética do humano - Compaixão pela Terra. 11. ed. Rio de Janeiro: Vozes, 1999. p. 45. 
Portanto, de acordo com esta fábula, o significado mítico e etimológico da palavra homem ${ }^{140}$ provém de húmus, terra fértil, desde que devidamente cuidada.

Modernamente, o vocábulo homem não comporta mais a definição de animal racional, pois apequena sua significativa superioridade em relação à espécie animal irracional, já que a ciência o reconhece como um ser capaz de ter sentimento, de emocionar-se, de envolver-se, de afetar e de ser afetado e de articular palavras e simbolizar, devido à sua capacidade de ser autoconsciente ${ }^{141}$. A ética do cuidado acolhe esta essência do ser humano "humano", isto é, o sentimento, a capacidade de simpatia e empatia, a dedicação, o cuidado e a comunhão com o diferente. Os sentimentos humanos expressam-se, basicamente, em três emoções: ternura, compaixão e cuidado.

Numa visão cartesiana, a atividade humana mais importante é a razão, daí a expressão: “penso, logo existo”. A visão contemporânea do homem, porém, pode ser expressa por: "sinto, logo existo". No entanto, com o conhecimento da física quântica ${ }^{142}$, a expressão do homem é: "escolho, logo sou". A dinâmica do humano é o sentimento, o cuidado, a lógica do coração. A mente emocional expressa-se pela intuição, num só impulso, ativa a lógica do coração, não a lógica mental.

A Fábula de Higino tem a capacidade imagética de mostrar que há uma natureza humana essencial, anterior ao espírito infundido por Júpiter ao corpo fornecido pela Terra. A fábula diz "o cuidado foi quem primeiro moldou o ser humano", portanto, o cuidado está ontologicamente, a priori, na origem do ser humano.

${ }^{140}$ SILVEIRA BUENO, Francisco da. Grande dicionário etimológico-prosódico da língua portuguesa, 4 v., p. 1.807. "Homem - s.m. Animal racional, ser humano, gênero humano, correspondendo ao gr. ánthropos. Lat. hominem, achando muitos que em homo exista o tema de húmus, chão, terra, comprovando a narração bíblica: e limo tarrae, corresponde ainda ao hebraico Adamah de que se fez Adão, cujo significado é ainda: feito de terra, animal, bicho da terra por excelência".

141 JUNG, Carl G. O homem e seus símbolos. Tradução de Maria Lucia Pinho. 4. ed. Rio de Janeiro: Nova Fronteira, 1964. p. 81: “O Fausto de Goethe diz muito acertadamente: 'In Anfang war die Tat' (No começo era o ato). 'Atos' nunca foram inventados, foram feitos. Já os pensamentos são uma descoberta relativamente tardia do homem. Primeiro ele foi levado, por fatores inconscientes, a agir; só muito tempo depois é que começou a refletir sobre as causas que motivaram a sua ação. E gastou muito mais tempo ainda para chegar à idéia absurda e disparatada de que ele mesmo se devia ter motivado, desde que seu espírito era incapaz de identificar qualquer outra força motriz senão sua própria. A idéia de uma planta ou de um animal se inventarem a si próprios nos faz rir, no entanto, muita gente acredita que a psique, ou a mente, inventaram-se a elas mesmas, e foram, portanto, o seu próprio criador".

142 O Direito Quântico será objeto de subtítulo no desenvolvimento do tema e será abordada a física quântica. 
É preciso compreender que essa essência apriorística não é apenas temporal, pois a existência humana é portadora da história da espécie, como bem comprovam os recentes estudos da Biologia e da bioética, que descobrem no DNA o repositório destas memórias remotas.

"Cuidado" moldou a criatura de barro, que recebeu o nome de homem, com o cuidado expresso pela ternura, devoção e sentimento, criando, com esta iniciativa, a responsabilidade sobre os cuidados existenciais com a sua criação.

Enfim, o resgate da ética do cuidado é a recuperação da capacidade de sentir o outro, de ter compaixão com todos os seres que sofrem, humanos e não humanos, de reconhecer a lógica do coração ${ }^{143}$, priorizando a cordialidade ${ }^{144}$, em lugar de privilegiar a lógica da conquista e do uso utilitário das coisas - e das pessoas.

A ética do cuidado tem despertado, nas últimas décadas, a responsabilidade da humanidade pelo meio ambiente. Com isso, há a implantação de políticas internas e externas em países ricos e em desenvolvimento, dado o perigo de rompimento de cadeias de organização da vida no planeta, em desobediência à dinâmica do ecossistema nativo, a qual é decorrente da ausência da ética do cuidado.

${ }^{143}$ BUARQUE DE HOLLANDA, Sérgio. Raízes do Brasil. 4. ed. Brasília: Editora UnB, 1963. p. 136-157. "A mescla de tanta miscigenação genética e cultural, dá lugar ao nascimento do brasileiro, apegado ao culto predominantemente católico, com padrões de um meio rural e patriarcal. Hospitaleiro, generoso, espontâneo, enfim, o homem cordial (...). A origem etimológica da palavra cordial é latina, vem de cordiale. Significa tudo aquilo que é relativo ao coração. Um cordial é o mesmo que um tônico para o coração. Em sentido figurado, significa afetuoso, afável, sincero e franco. O temperamento do brasileiro é de reverência. Porém, é avesso ao ritualismo social que afasta a possibilidade de estabelecer intimidade. É movido por uma ética de fundo emotivo, tão peculiar, em virtude das raízes da formação do povo, que raros estrangeiros chegam a penetrar, nem mesmo os portugueses. Uma característica do brasileiro a demonstrar este temperamento é a forma de tratamento social com a tendência de omitir o nome de família, privilegiando o nome de batismo. Esta atitude é uma forma de abolir, psicologicamente, as barreiras que distanciam pela identificação pelo nome coletivo, ou sobrenome, em lugar do individual, ou do nome próprio".

144 A palavra cordialidade - derivado de cordial, portanto, da mesma raiz latina cordialis, cor, cordis, coração. 


\subsubsection{TU nasce antes do EU}

Retomando a mudança paradigmática da definição de homem ("penso, logo existo" transformada em "sinto, logo existo" e depois "escolho, logo sou") acrescente-se à essência deste ser a mais misteriosa das funções humanas - a fala -, pela qual se constrói o mundo com suas relações por meio da palavra ${ }^{145,146}$. Neste enfoque, pode-se afirmar que homem é um ser que pensa, que sente, que fala e que escolhe. Eis a definição completa e contemporânea acerca do ser humano, que constitui sua plenitude.

Trata-se de um processo complexo e sua compreensão é fundamental para a perfeita atuação do profissional que lida com o jurisdicionado. Como o eu somente se constitui mediante diálogo com o $t u$, este possui uma anterioridade sobre o $e u$. O $t u$ é o agente que atua para que o $e u$ aflore.

Em síntese, o jurisdicionado em crise e, na maioria das vezes, em sofrimento, está em busca do $e u$, e o profissional que tem a atribuição jurisdicional de cuidar daquele sujeito de direito (inserido em relações familiares conflituosas) tem a responsabilidade de ser um $t u$, concreto, com rosto, olhar e fisionomia, com os quais o outro se identifica, porque vê sua imagem e semelhança. Leonardo Boff aponta que:

${ }^{145}$ GUSDORF, Georges. La parole. 2. ed. Vendôme: PUF, 1952. p. 5, tradução livre: "A linguagem é uma função psicológica correspondente a um conjunto de dispositivos anatômicos e fisiológicos, prolongandose em montagens intelectuais para se sistematizar em um complexo exercício de conjunto, característica única da espécie humana, dentre todos as espécies de animais. A língua é um sistema de expressão falada particular a tal ou qual comunidade humana. O exercício da linguagem produz ao longo do tempo uma espécie de depósito sedimentário que toma valor de instituição e se impõe sobre o falar individual, sob as espécies de um vocabulário e de uma gramática. A palavra designa a realidade humana de acordo com a expressão, não mais função psicológica, nem realidade social, mas afirmação da pessoa, da ordem moral e metafísica. A linguagem e a língua são dados abstratos, as condições de possibilidade da palavra, que as encarna, assumindo-as para fazê-las passar ao ato. Só existem homens que falam, capazes de linguagem, e que se situam no horizonte de uma língua. Existe uma hierarquia de degraus de significação a partir de um simples som vocal, que se estiliza em palavra pela imposição de um sentido social, até a palavra humana efetiva, carregada de intenções particulares, mensageira de valores pessoais".

146 GUSDORF, Georges. La parole, p. 7: "L'homme est un animal qui parle: cette definition, après tant d'autres, est, peut-être, la plus décisive. Elle recouvre et absorbe les définitions traditionelles, par le rire ou la sociabilité. Car le rire de l'homme affirme um langage de soi à soi et de soi aux autres" (O homem é um animal que fala: esta definição dentre tantas outras, é talvez, a mais decisiva. Ela recupera e absorve as definições tradicionais, pelo rir ou pela sociabilidade. Pois o rir do homem afirma uma linguagem de si a si e de si aos outros). 
"O rosto possui um olhar e uma irradiação da qual ninguém pode subtrair-se. O rosto e o olhar lançam sempre uma proposta em busca de uma resposta. Nasce assim a responsabilidade, a obrigatoriedade de dar respostas (...). Cuidar do outro é zelar para que a dialogação, esta ação de diálogo eu-tu, seja libertadora, sinergética e construtora de aliança perene e de amorização". ${ }^{147}$

Há aí um reconhecimento mútuo, um diálogo do $t u$ com o eu, pois o rosto do outro provoca, evoca e convoca em busca de uma resposta. Quando o juiz dá a resposta, em forma de prestação jurisdicional, este realiza o movimento inverso, pois busca no $t u$ do jurisdicionado o seu eu, em verdadeira comunicação humana, confirmando sua pertença à humanidade que os vincula. Realiza-se, assim, a ética do cuidado.

Para compreender a formação do tu e do eu é necessário promover uma análise da fala e da palavra.

\subsubsection{A fala e a palavra}

A obra clássica de Georges Gusdorf ${ }^{148}$, intitulada Parole, tratou com profundidade a fala e a palavra, destacando-se os seguintes ensinamentos:

a) não há, no corpo humano, um órgão próprio ou exclusivo para a função da fala, pois são acionadas várias disposições anatômicas, tais como, cordas vocais, estruturas cerebrais, pulmões, língua, boca, aparelho auditivo, pois o surdo de nascença é obrigatoriamente mudo, concluindo que, em comparação do humano com o chimpanzé - este incapaz de emitir palavra, mas meros sons - “a função da palavra, em sua essência, não é uma função orgânica, mas uma função intelectual e espiritual";

\footnotetext{
${ }^{147}$ BOFF, Leonardo. Saber cuidar - Ética do humano - Compaixão pela Terra, p. 139.

148 GUSDORF, Georges. La parole, p. 8.
} 
b) a aventura do pensamento ocidental começa quando a reflexão grega traz à luz a autonomia da palavra ${ }^{149}$ humana - tomar a palavra $^{150}$ - um ato de criação, "a palavra, dizia Henri Delacroix, é criada cada vez que é emitida", "a linguagem manifesta a transcendência da realidade humana, a única capaz de constituir o mundo. A linguagem constitui a essência do mundo e a essência do homem"151;

c) a palavra dá nome às coisas, permitindo que ocupem seu espaço na ordem do mundo, "A denominação afirma um direito à existência, são as palavras que fazem as coisas e as pessoas, que definem as relações segundo as quais se constitui a ordem do mundo ${ }^{152}$ ”;

d) as relações humanas são constituídas no espaço das palavras: "a palavra é o meio necessário da comunicação, que consagra o momento no qual ela cria uma nova linguagem, o momento no qual o "nós" se realiza na aliança do "eu" e do "tu"153.

O recorte seletivo das assertivas colhidas na obra de Geoges Gusdorf elucida a função da fala como ato de criação, significando que, a cada palavra emitida, há a reafirmação do elo que explica o passado e engaja o futuro, caracterizando a natureza persistente ${ }^{154}$ da linguagem como sistema vivo e animado por movimento, em constante renovação.

149 GUSDORF, Georges. La parole, p. 37.

${ }^{150}$ ARENDT, Hannah. A condição humana. 10. ed. Tradução de Roberto Raposo, posfácio de Celso Lafer. Rio de Janeiro: Forense Universitária, 2005. p. 36: Segundo a autora, a violência é muda, pois atua onde cessam o discurso e a argumentação. Por isso, jamais pode ter grandeza. Para os gregos, forçar alguém a fazer algo mediante violência, ordenar ao invés de persuadir, eram modos pré-políticos de lidar com as pessoas, típico da vida fora da pólis, isto é, nos impérios bárbaros da Ásia. Curiosamente, era também uma característica da vida em família, no qual o chefe da casa imperava com poderes incontestes e despóticos.

151 GUSDORF, Georges. La parole, p. 38.

152 GUSDORF, Georges. La parole, p. 41.

${ }^{153}$ GUSDORF, Georges. La parole, p. 60.

${ }^{154}$ GUSDORF, Georges. La parole, p. 39. 
Deste conhecimento sobre a importância da palavra para a constituição do indivíduo, é preciso buscar a compreensão sob a ótica interdisciplinar. Com apoio no conhecimento da psicanálise ${ }^{155}$ depreende-se que: a) há cura pela linguagem; b) a psicanálise é a ciência da singularidade; c) a experiência de ser escutado é muito significativa para o ser humano.

A experiência psicanalítica representa a possibilidade, desejada por todos os humanos, de ser escutado. A atividade de escutar não contém julgamento das palavras ou de comportamentos, pois está voltada ao inconsciente. Já a atividade de ouvir é completamente diferente de escutar, pois superficial, contendo julgamento das palavras e do comportamento.

Enfim, a função humana da fala representa um movimento criativo, que depende da vontade, da iniciativa do sujeito em direção ao outro, portanto, a palavra exerce uma função de integração social, pois “(...) a linguagem impõe a disciplina da exteriorização. $O$ uso da palavra é, portanto, uma das causas essenciais do mal da consciência, muito mais essencial do que podemos pensar ${ }^{156,}$.

\subsubsection{O primeiro $E \boldsymbol{U}$}

Há um longo caminho para se poder dizer eu. A constituição do eu passa pelo $t u$, como descreve Carlos Altemir Schimitt:

“Aqui encontramos o lugar do nascimento da ética que reside nesta
relação de responsabilidade diante do rosto do outro e
particularmente do mais outro que é o oprimido. É na acolhida ou
na rejeição, na aliança ou na hostilidade para com o rosto do outro

${ }^{155}$ PHILLIPS, Adam. In: Revista Veja, São Paulo, edição 1793, n. 10, ano 36, 12 de março de 2003, p. 1115. Entrevista de páginas amarelas: A cura pela palavra.

${ }^{156}$ GUSDORF, Georges. La parole, p. 45. 
que se estabelecem as relações mais primárias do ser humano e se decidem as tendências de dominação ou de cooperação". ${ }^{157}$

Esta ação de diálogo - eu e tu - só se constitui pela ética do cuidado - "sinto, logo existo" - para que exerça a função libertadora e construtiva de alianças com o $t u$, o que se dá pela forma homem e mulher, que, embora diferentes, pertencem à humanidade. Os dois tu que se encontram realizam a singularidade - o $e u$ - a essência humana, em relação de reciprocidade.

Para Carl G. Jung ${ }^{158}$, o homem e a mulher possuem, dentro de si, o animus (a dimensão do masculino) e a anima (a dimensão do feminino). No entanto, no diálogo, o homem desperta na mulher sua dimensão expressa culturalmente pelo modo-de-sertrabalho, e a mulher evoca no homem sua dimensão feminina, concretizada, historicamente e por uma questão de gênero, pelo modo-de-ser-cuidado.

As relações devem propiciar a manifestação das diferenças, que não podem ser entendidas como desigualdades, e sim como riqueza da única e complexa substância humana, por meio da convergência na diversidade para a criação de espaço e para uma experiência integrada, da qual decorre a legitimação da própria "humanidade" do ser humano. Enfim, é da ética do cuidado que nasce o eu.

A expressão do nascimento do eu pela ótica do Direito, é exemplificado por Jean Carbonnier $^{159}$ ao explicar como se constitui a gênese do mecanismo de direito subjetivo na criança, o nascimento espontâneo do sentimento de posse, que se expressa como meus direitos. O autor afasta a hipótese clássica, na qual os estudos de psicologia jurídica revelam que os direitos se transmitem pelo instinto de imitação do direito adulto. Isso porque a psicologia moderna fundamenta que o despertar do sentimento da posse, na

\footnotetext{
${ }^{157}$ SCHIMITT, Carlos Alberto. Concepções e práticas de cuidado humano no cotidiano de uma organização: uma configuração ética e estética de vida no espaço laboral. 2003. Dissertação (Mestrado) área de concentração: engenharia de produção. Universidade Federal de Santa Catarina, Santa Catarina. p. 132. defendida e aprovada em 20.06.2003.

158 JUNG, Carl G. O homem e seus simbolos, p. 30.

159 CARBONNIER, Jean. Flexible droit, p. 172-179.
} 
criança, ocorre numa idade em que a imitação dos adultos ainda não está presente no infante. Desde os dois anos de idade manifesta-se, gradualmente, o instinto de ter o objeto e defendê-lo, manifestando irritação, encolhimento, enfim, a verdadeira substância biológica do direito subjetivo. O direito subjetivo traduz a noção de um fenômeno psicossocial elementar, visceral, instintivo.

O direito está, ao mesmo tempo, fora e dentro do indivíduo, mas a natureza do direito subjetivo é sociológica, pois para ser eu é preciso relacionar-se com $t u$. E, numa relação de reciprocidade, para que o direito objetivo esteja presente na sociedade é preciso, antes, subjetivá-lo, com a conjugação do verbo na primeira pessoa.

Marie Balmary ${ }^{160}$ debruçou-se sobre a busca da aptidão humana para dizer eu. A autora conclui que esta genealogia da primeira pessoa tem sua origem no encontro do homem e da mulher - são dois $t u$ que, quando se encontram e se reconhecem em sua igualdade - pertença à humanidade - e, ao mesmo tempo, em sua diferença - anima $e$ animus - ocorre o nascimento do eu. "Tu, é o parteiro do eu”, como afirma Carlos Altemir Schmitt ${ }^{161}$.

Balmary ${ }^{162}$ constatou que, mesmo os lingüistas não conseguiram descrever o início da palavra. A autora, com sua experiência clínica como psicanalista, atividade que tem por objetivo levar o paciente a ter acesso ao verbo, afirma que o eu não é objeto de um saber, de uma competência, e sim a uma experiência humana: "É uma experiência de verdade, não a aquisição de um saber ou 'um trabalho sobre si mesmo' como se diz, freqüentemente ${ }^{163 \%}$.

Diante da constatação de que não há explicação científica acerca da origem da palavra, e, conseqüentemente, não há resposta da ciência para explicar quando e como o humano diz eu pela primeira vez, Balmary encontra esta resposta na linguagem simbólica,

160 BALMARY, Marie. La divine origine. Dieu n'a pas crée l’homme. Paris: Bernard Grasset, 1993.

161 SCHIMITT, Carlos Alberto. Concepções e práticas de cuidado humano no cotidiano de uma organização, p. 83.

${ }^{162}$ BALMARY, Marie. La divine origine. Dieu n'a pas crée l'homme, p. 48.

163 BALMARY, Marie. La divine origine. Dieu n'a pas crée l'homme, p. 49. 
inscrita no livro mais lido pela humanidade - a Bíblia - contendo na gênese a imagética do encontro de Adão e Eva - o primeiro homem e a primeira mulher -, descrevendo o encontro de animus e anima.

O primeiro livro da Bíblia ${ }^{164}$, o Gênesis, capítulo 3, com o subtítulo A queda do homem, introduz a primeira pessoa somente no versículo 10: "Ouvi a tua voz no jardim e, porque estava nu, tive medo e me escondi". Em seguida, no versículo 11: "Perguntou-lhe Deus: Quem te fez saber que estavas nu? Comeste da árvore de que te ordenei que não comesses?", o homem responde no versículo 12: "Então disse o homem: A mulher que me deste por esposa, ela me deu da árvore, e eu comi”.

Observe-se que, nos versículos anteriores, somente Deus falou na primeira pessoa, mas o primeiro eu humano foi atribuído a Adão. No versículo 10, o pronome ainda fíca oculto, e ele responde a Deus falando de seu sentimento de medo e vergonha ${ }^{165}$, e só o verbo indica a primeira pessoa do singular; mas, no versículo 12, Adão se destaca do coletivo e da natureza, quando se encontra com Eva, e, ao falar dela para Deus, sente medo e vergonha, e como acentua Balmary ${ }^{166}$ : "a primeira pessoa humana chega depois da falta e não antes. Adão já havia falado, mas somente na terceira pessoa, para acolher a mulher. 'Ela é osso do meu osso e carne da minha carne'”.

O segundo $e u$ humano é falado pela mulher de Adão, que só recebe o nome de Eva depois da expulsão do paraíso. No versículo 13: "Disse o Senhor Deus à mulher: Que é isso que fizeste? Respondeu a mulher: A serpente me enganou e eu comi”.

O primeiro eu falado por Adão e depois por Eva só ocorreu quando houve o encontro animus e anima - na diferença de homem e mulher, mas na semelhança da

164 BÍBLIA SAGRADA. Tradução de João Ferreira de Almeida. Rio de Janeiro: Sociedade Bíblica do Brasil, 1960. p. 9.

165 SILVEIRA BUENO, Francisco da. Grande dicionário etimológico-prosódico da língua portuguesa, p. 4227: VERGA - vara, travessa, pau atravessado (...) Lat. virga, possivelmente do mesmo tema de viridis, verde, no sentido de tenro, flexível. Gíria: membro viril, pênis".

166 BALMARY, Marie. La divine origine. Dieu n'a pas crée l'homme, p. 51. 
qualidade humana. Portanto, o tu nasce antes do $e u$, porque assim se constitui a pessoa, que precisa do outro para exercer sua aptidão de autoconsciência.

Em complemento, Balmary faz uma reflexão merecedora de destaque: “O primeiro eu sujeito dito pelo humano é um eu infeliz, temente ao outro, um eu nu no sentido de 'despojado', um eu só, que perdeu o tu. Não é bom que o homem seja só no mundo, nem que EU seja só na palavra".

O conhecimento do longo caminho do tu ao eu é imprescindível para a compreensão da importância da ética do cuidado.

Colhendo-se um recorte da Fábula de Higino, "o cuidado foi quem primeiro moldou o ser humano", observa-se que o cuidado está ontologicamente a priori à existência do ser humano, portanto representa o $t u$ que está na origem da formação do $e u$ capaz de ser sujeito de direito.

A ética do cuidado dá-se no cotidiano, no comportamento mais simples que se possa pensar e, quando a ação de cuidar atua, ela tem um grande poder pedagógico, que se repete em rede, com abrangência inimaginável.

O profissional que trabalha com os conflitos familiares em momento que antecede ou já em sede do Judiciário, com formação, disciplina, treino e, sobretudo, método, conhecimento teórico e vocação - elemento primordial para garantir a emoção na construção do diálogo $e u$ e $t u$ - pode alcançar uma qualidade de prestação jurisdicional inacreditável, porque dá amplitude à sua capacidade criativa, apequenada pelo extremo rigor técnico-jurídico. No entanto, este é um paradigma da modernidade, já ultrapassado e ineficaz para o sujeito de direito pós-moderno.

A essência da prestação jurisdicional para conflitos familiares está no conhecimento interdisciplinar e na formação especializada. A atividade do Estado realiza-se 
pela comunicação entre humanos, pela escuta que, tecnicamente, concretiza-se pela predominância do princípio da oralidade ${ }^{167}$, dando voz ao sujeito de direito. Esta atuação, bem conduzida e com sentido, poderá promover o restabelecimento do desvio de função e de papéis no sistema familiar. Esta é a origem do conflito que chega ao Judiciário, cujos efeitos são avassaladores, de um modo geral, mas a restauração da ordem nos papéis familiares é muito simples, desde que conte com a atuação competente de um profissional especializado, com formação interdisciplinar.

A ética do cuidado é a atividade humana de preservação da vida. Tudo que existe precisa ser cuidado para continuar a existir e a viver: uma planta, um animal, uma criança, um idoso, o planeta Terra. Trata-se, enfim, de decorrência da dignidade da pessoa humana.

A ética do cuidado é uma preciosa ferramenta para realizar a concretude da doutrina pós-moderna para dar eficácia plena ao Direito de Família. No entanto, este comportamento exige conhecimento interdisciplinar.

\subsection{INTERDISCIPLINARIDADE}

A ética do cuidado e o conhecimento pós-moderno exigem linguagem interdisciplinar. Hilton Japiassu atribui conceito de natureza universal à interdisciplinaridade:

“corresponde a uma evolução dos tempos atuais, resultante de um caminho irreversível, vindo preencher os vazios deixados pelo saber proveniente das áreas de especialidade do conhecimento, constitui importante instrumento de reorganização do meio científico, a partir da construção de um saber que toma por empréstimo os saberes de outras disciplinas, integrando-os num

${ }^{167}$ O princípio da oralidade será objeto de estudo e sugestão de predominância, no próximo capítulo. 
conhecimento de um nível hierarquicamente superior, desencadeando uma transformação institucional mais adequada ao bem da sociedade e do homem."

Entre os profissionais das ciências jurídicas, há um conceito equivocado de interdisciplinaridade. A idéia é que um atendimento interdisciplinar deve ser feito por, no mínimo, dois profissionais de diferentes áreas do saber. No caso dos conflitos de Direitos de Família, a idéia de excelência interdisciplinar - repita-se, equivocada - é que os sujeitos do conflito sejam atendidos, simultaneamente, por um advogado e por um psicólogo.

Como se extrai do conceito apresentado, a produção de conhecimento interdisciplinar é oriunda da adoção de uma atitude individual, construída com suporte na observação e na cooperação com outros saberes. Para tanto, é preciso despertar, no pesquisador, uma nova manifestação de inteligência e uma nova pedagogia, opondo a extrema especialização à propedêutica interdisciplinar.

Há, também, uma forte tendência de confundir a interdisciplinaridade com a organização do conhecimento pelo enfoque do paradigma da modernidade, que privilegiava a disciplinaridade ${ }^{169}$ devido à extrema especialidade do conhecimento. A contribuição da era da especialidade do conhecimento levou o homem ao apogeu de uma sociedade tecnologicamente desenvolvida. É preciso conscientizar-se, porém, de que outra era da realidade humana clama por uma inversão do significado do saber, voltando à essência do homem, recuperando, assim, o equilíbrio ontológico.

Nos primórdios do paradigma da pós-modernidade, houve a necessidade inicial de ampliação do conhecimento disciplinar, a exemplo de Jean Carbonnier, um dos primeiros juristas interdisciplinares, que desenvolveu uma ousada abordagem do Direito Civil pelo

168 JAPIASSU, Hilton. Interdisciplinaridade e patologia do saber, p. 72.

169 JAPIASSU, Hilton. Interdisciplinaridade e patologia do saber, p. 70: "disciplinaridade é a exploração científica especializada de determinado domínio homogêneo de estudo, isto é, o conjunto sistemático e organizado de conhecimentos que apresentam características próprias nos planos do ensino, da formação, dos métodos, e das matérias; esta exploração consiste em fazer surgir novos conhecimentos que se substituem aos antigos". 
flanco da sociologia ${ }^{170}$. Inicialmente, houve margem aos primeiros ensaios para a globalização do conhecimento científico, surgindo uma tendência de atividades pluridisciplinares e multidisciplinares ${ }^{171}$. No entanto, os limites de tais práticas logo foram estabelecidos, ampliando, assim, a produção do conhecimento interdisciplinar.

O Código de Família brasileiro fundamenta-se no conhecimento interdisciplinar, atribuindo-lhe qualidade peculiar, pois amplia a importância dos institutos pela compreensão da dinâmica humana com aporte da psicanálise, da psicologia, da sociologia, da Biologia, da Medicina, da Engenharia genética etc.

Este conhecimento interdisciplinar como conteúdo do Código de Família brasileiro é tão abrangente que não pode ser organizado com linguagem hermética, mas fundamentado em pluralidade de fontes e comunicação qualificada, marcada pela narrativa de atitudes positivas que levam à alegria de viver - revival. Enfim, são estes os valores pós-modernos.

Luiz Edson Facchin ${ }^{172}$ expressa com vigor estas idéias pós-modernas sobre codificação para o jurista de amanhã: "para atingir esta conjectura, o caminho a ser tomado não é o da técnica, mas aquele da arte".

Um importante exemplo de interdisciplinaridade jurídica foi a construção do conceito de afeto como bem jurídico, com apoio no conhecimento de outras ciências. Tomando-se a contribuição da pedagoga interdisciplinar Diva Spezia Ranghetti ${ }^{173}$ : "afetividade é afetar e ser afetado pelo outro, instigando as energias e ativando nosso eu para a ação". Essa noção leva ao entendimento de que o conteúdo do Direito de Família

${ }^{170}$ CARBONNIER, Jean. Sociologie juridique, editado em 1978.

${ }^{171}$ JAPIASSU, Hilton. Interdisciplinaridade e patologia do saber, p. 74 "multidisciplinaridade é uma gama de disciplinas adotadas simultaneamente, abstraídas as relações existentes entre si, e pluridisciplinaridade, ao contrário, caracteriza-se pela justaposição de diversas disciplinas situadas geralmente no mesmo nível hierárquico e agrupadas, mantendo-se as relações existentes.

${ }^{172}$ FACHIN, Luiz Edson. Le juriste de demain et la connaissance du code civil. Revista de Informação Legislativa, Brasília: n. 162, ano 41, abr.jun. 2004. p. 236. Trata-se de um artigo escrito em francês, publicado na França.

${ }^{173}$ RANGHETTI, Diva Spezia. Afetividade. In: Dicionário em Construção. Organizado por Ivani Fazenda. São Paulo: 2. ed. Rio de Janeiro: Cortez, 2002. p. 87. 
pós-moderno é toda relação de afeto, este compreendido em sua inteireza, e não apenas pela ótica de amor e carinho, como costumam interpretar os unidisciplinares.

A interdisciplinaridade envolve complexidade que leva à universalidade do pensamento e do conhecimento, decorrente da axiomática comum a um grupo de disciplinas conexas, cujo sentido é a noção de finalidade. Lídia de Almeida Prado acrescenta:

\begin{abstract}
"a interdisciplinaridade amplia a potencialidade do conhecimento humano, pela articulação entre as disciplinas e o estabelecimento de um diálogo entre os mesmos, visando à construção de uma conduta epistemológica. (...) A interdisciplinaridade é considerada como a mais recente tendência da teoria do conhecimento, decorrência obrigatória da modernidade, por se tratar de um saber oriundo da predisposição para um "encontro" entre diferentes pontos de vista (diferentes consciências), o que pode levar, criativamente, à transformação da realidade". ${ }^{174}$
\end{abstract}

O Código de Família brasileiro deverá, portanto, ser interpretado e aplicado por profissionais com formação interdisciplinar para que o resultado da atividade jurisdicional seja de natureza transdisciplinar ${ }^{175}$.

${ }^{174}$ ALMEIDA PRADO, Lídia. O juiz e a emoção, p. 3.

${ }^{175}$ Os participantes do Primeiro Congresso Mundial de Transdisciplinaridade (Convento da Arrábida, Portugal, 2 a 7 de novembro de 1994) adotam a presente Carta, entendida como um conjunto de princípios fundamentais da comunidade dos espíritos transdisciplinares, constituindo um contrato moral que todo signatário dessa Carta faz consigo mesmo, livre de qualquer espécie de pressão jurídica ou institucional. Artigo 1 - Toda e qualquer tentativa de reduzir o ser humano a uma definição e de dissolvêlo no meio de estruturas formais, sejam quais forem, é incompatível com a visão transdisciplinar. Artigo 2 - O reconhecimento da existência de diferentes níveis de realidade, regidos por lógicas diferentes, é inerente à atitude transdisciplinar. Toda tentativa de reduzir a realidade a um só nível, regido por uma lógica única, não se situa no campo da transdisciplinaridade. 


\subsection{DIGNIDADE DA PESSOA HUMANA}

A ética do cuidado expressa pela linguagem interdisciplinar veicula os valores pós-modernos, podendo ser condensada em uma frase de Goethe, cujo conteúdo revela, na prática, como atua esta conduta humana para que o "tu seja parteiro do $e u^{176 ": ~ " S e ~ u m ~}$ indivíduo for tratado em função daquilo que ele é, assim ele permanecerá. Se for tratado como se ele já fosse aquilo que poderia ser, assim se tornará”.

O Código de Família Brasileiro tem como fundamento principiológico e paradigmático a dignidade da pessoa humana, inserido na Constituição Federal brasileira, promulgada em 5 de outubro de 1988. Marco revolucionário no Direito de Família, a Constituição Federal consagra a doutrina pós-moderna, adotando o pluralismo de fontes, para acolher as famílias em suas diversas formas: casamento, união estável, família monoparental e tantas outras quantas possam surgir das famílias em ordem e em desordem.

A dignidade da pessoa humana é fato recente para o Direito, já que, para outras áreas do conhecimento, seu conceito tem tradição histórica. A dignidade é um postulado axiomático $^{177}$ de ordem jurídica, um postulado ético que orienta o ordenamento jurídico. Portanto, a dignidade não é um conceito de direito positivo, mas só pode ser reconhecida por este, o qual organizará a proteção e a salvaguarda das garantias da dignidade da pessoa humana.

Giselda Maria Fernandes Novaes Hironaka levanta a questão terminológica atinente à necessidade de esmiuçar o porquê da adoção, aparentemente redundante, da expressão formada por duas palavras designativas do mesmo conteúdo: pessoa e humana.

"Por que não se usou a expressão mais restritiva como dignidade da pessoa ou, simplesmente, dignidade humana? Mas foi assim

${ }^{176}$ BOFF, Leonardo. Saber cuidar - Ética do humano - Compaixão pela Terra, p. 139.

${ }^{177}$ BORELLA, François. Le concept de dignité de la personne humaine. In: Ethique, Droit et Dignité de la Personne. Mélanges Christian Bolze. PEDROT, Philippe (Coord.). Paris: Ed. Economica, 1999. p. 37. 
que preferiu o legislador constituinte. (...) Além disso, o sentido que se atribui a essa expressão tem sido, quase sempre, mais coloquial do que um sentido científico, e a grande prova disso reside no fato de não se definir a dignidade da pessoa humana antes de se falar dos seus efeitos ou de sua importância." 178

Historicamente, a necessidade de construção de um conceito jurídico da dignidade da pessoa humana remonta à época da segunda guerra mundial. A idéia é decorrente dos efeitos do nazismo, que havia lançado a hipótese da existência de uma raça humana pura, a ariana (hipótese que Hitler tentou comprovar). Para salvaguardar a humanidade, foi necessário definir a essência de ser humano e a proteção jurídica da dignidade da pessoa humana, como reação ${ }^{179}$ à ideologia nazista, separando os homens dos sub-homens.

Antonio Junqueira Azevedo ${ }^{180}$ aponta as primeiras fontes do uso da expressão dignidade, com conteúdo jurídico:

a) 1947 - Constituição da República Italiana: "Todos os cidadãos têm a mesma dignidade social e são iguais perante a lei (...)";

b) 1948 - Declaração Universal dos Direitos do Homem: Considerando que o reconhecimento da dignidade inerente a todos os membros da família humana (...)";

c) 1949 - "Lei Fundamental” da Alemanha: "A dignidade do homem é intangível".

A importância da atualização do conceito de dignidade e de pessoa humana fundamentou a necessidade de legislar sobre bioética. Em 27 de julho de 1994, o Conselho Constitucional da França enfatizou o citado artigo 16 do Código Civil, para exaltar o

\footnotetext{
${ }^{178}$ HIRONAKA, Giselda Fernandes Novaes. Responsabilidade pressuposta. Belo Horizonte: Del Rey, 2005. p. 162.

179 BAUDOUIN, Jean-Louis. Ethique, droit et dignité de la personne - Mélanges Christian Bolze. PEDROT, Philippe (Coord.). p. IX. Ed. Economica, Paris , 1999.

180 AZEVEDO, Antonio Junqueira. Caracterização jurídica da dignidade da pessoa humana. Revista dos Tribunais, São Paulo, ano 91, n. 797, p. 11-25, mar. 2002.
} 
princípio de salvaguarda da dignidade da pessoa humana - a saisine da humanidade do homem. Eis, mais uma vez presente, a conquista da ciência dinamizando o Direito.

Bernard Edelman empresta importante contribuição às ciências jurídicas, ao se debruçar sobre a interpretação do princípio da dignidade da pessoa humana como uma mudança de dimensão dos direitos do homem, que não são mais centrados no direito de propriedade, mas na dignidade. Segundo o autor:

"Para compreender essa moderna dimensão é preciso analisar a liberdade, que se tornou insuficiente, na forma como foi inscrita nos direitos humanos. Se a dignidade exige a liberdade, esta não é toda a dignidade. Dignidade e liberdade não se opõem, pois a liberdade, nessa nova leitura, submete-se à dignidade. (...) Todos os seres humanos compõem a Humanidade, que se apresenta como a reunião simbólica de todos os homens naquilo que eles têm de comum - a qualidade de seres humanos - permite $o$ reconhecimento de uma pertença a um mesmo gênero: o gênero humano. A dignidade é a qualidade dessa pertença. Se a liberdade é a essência dos direitos humanos, a dignidade é a essência da humanidade". 181

Este conceito tem orientado as recentes codificações, inserindo, sistematicamente, a pessoa como portadora de vontade abstrata. Trata-se de uma liberdade contratual em movimento, como bem analisa Jacqueline Pousson-Petit ${ }^{182}$ : "A moderna tendência do direito privado é a orientação que acompanha a teoria dos direitos da personalidade, garantindo a proteção da integridade física e moral da pessoa humana, proclamando, ainda, a primazia do ser humano".

${ }^{181}$ EDELMAN, Bernard. La dignité de la personne humaine, un concept nouveau. In: PAVIA, Marie Luce; REVET, Thierry (Org.). La dignité de la personne humaine. Paris: Economica, 1999. p. $26-27$.

${ }^{182}$ POUSSON-PETIT, Jacqueline. Liber Amicorum Marie Thérèse Meulders-Klein Droit Comparé des Personnes et de la Famille. Établissement Emile Bruylant, Bruxelas, 1998. p. 505. 
Eis porque a noção de dignidade paira no ar. Nos tempos atuais, é lembrada quando se fala de excluídos, de um modo geral. Entretanto, no passado, desde os gregos, dignidade era uma virtude política ligada às funções políticas e sociais, que lhe atribuíam o estatuto de homem livre.

A dignidade da pessoa humana contém valor principiológico e paradigmático, pois simboliza o deslocamento valorativo da concentração do Direito sobre a propriedade para pôr o olhar sobre a pessoa humana e, conseqüentemente, sobre a vida. Conforme ressalta Leonardo Boff:

"Esse fenômeno reside na vida como vida humana; consiste no fato de que alguém está aí, vivo e presente. Toda vida, particularmente a humana, constitui uma realidade indisponível, não descartável, e, de certa forma, irredutível. Vida é algo que nós não produzimos, mas acolhemos. É um fenômeno que emerge de forma misteriosa dentro da criação". 183

Para que haja coerência nos fundamentos teóricos do Código de Família brasileiro sua interpretação e aplicação deverão obedecer a seguinte ordem: ética do cuidado, por meio da linguagem da interdisciplinaridade, norteada pelo princípio-paradigma da dignidade da pessoa humana, empregando-se a preponderância da inteligência intuitiva. Eis o conteúdo do Direito Quântico.

183 BOFF, Leonardo. A voz do arco-íris, p. 53. 


\subsection{INTUIÇÃO}

A interdisciplinaridade e a permissividade de manifestar a emoção como valor da pós-modernidade exigem, em corolário, a manifestação da inteligência intuitiva ${ }^{184}$, cujos fundamentos foram desenvolvidos como filosofia da intuição.

Coube a Henri Bergson (1859-1941), francês de origem judaica, nascido em Paris nos meados do século XIX, explica o funcionamento da intuição, opondo-se ao pensamento que considerava absoluto o conhecimento científico, como predominava em seu tempo, na era da modernidade.

Bergson $^{185}$, conhecido como espiritualista e intuicionista, propugnou pela intuição como verdadeiro método de investigação filosófica e desenvolveu seu pensamento pelo enfoque da filosofia da vida e da filosofia da intuição, baseando-se em três princípios: todas as coisas se movem, teoria de intuição e o $e u$ do momento.

Para fundamentar o Código de Família brasileiro é a teoria da intuição que importa, pois, demonstra que é impossível ver as coisas exatamente como elas são, captar o seu verdadeiro sentido, sem cometer o mínimo engano. Os conceitos formados pela instrução, pela tradição cultural, pelos costumes etc., manifestam-se em todos os pensamentos e percepções.

O conhecimento da filosofia da intuição permite que se ultrapasse esta barreira inconsciente e que o observador perceba a impressão instantânea captada pela intuição. Como todas as coisas se movem, porque tudo está em contínuo movimento, o eu do momento, na teoria de Bergson, muda a cada instante e percebe sempre de modo diferente,

184 SILVEIRA BUENO. Grande dicionário etimológico-prosódico da língua portuguesa, p. 1973. "Intuição: Conhecimento direto, imediato, sem necessidade de provas e raciocínios. Compreensão rápida, pressentimento. Lat. tard. intuitionem usado por Santo Irineu".

185 RIZZATTO NUNES, Luiz Antonio. A intuição e o direito: um novo caminho. Belo Horizonte: Del Rey, 1997. p. 16. 
atual. Isso pode-se dizer a respeito do mundo, da sociedade dos pensamentos e das circunstâncias.

A teoria de Bergson tem efeitos pragmáticos que podem ser aferidos no cotidiano. É claro que há pessoas que desenvolvem com maior facilidade esta capacidade, mas há pessoas muito arraigadas a preconceitos ou ao positivismo, afastando-se desta emocionalidade inerente ao humano e revalorizada na doutrina pós-moderna.

Bergson não limita a percepção do mundo do conhecimento, mas procura concretizar o pensamento, reconhecendo-lhe a força criativa, com uma visão pragmática, influenciando a vida diária, produzindo resultados reais.

Nesta teoria há distinção entre inteligência e intuição. A inteligência realiza sua essência na técnica, é uma função prática de cálculo, previsão etc. A intuição transcende a inteligência, pois, apóia-se no interior da vida, numa fonte de conhecimento.

Rizzatto Nunes ${ }^{186}$ conclui que na teoria da intuição, em Bergson, "a matéria é um conjunto de imagens situadas a meio caminho entre a 'coisa' e a 'representação' (...) É a única forma de atingir o 'absoluto'. Enfim, trata-se de um processo peculiar de memória”.

Analisada superficialmente as características da teoria da intuição, num pensamento pós-moderno, deve-se dizer qual é a utilidade da intuição como fundamento do Código de Família brasileiro. A resposta é muito simples: trata-se de ferramenta para a interdisciplinaridade, para a percepção dos desvios de funções e papéis no sistema familiar, atuando, assim, sobre os conflitos familiares. É útil, ainda, para o entendimento do princípio da oralidade, praticado como escuta e exercício da palavra, pois dá voz ao jurisdicionado.

${ }^{186}$ RIZZATTO NUNES, Luiz Antonio. A intuição e o direito, p. 235. 
PARTE II

FUNDAMENTOS PRÁTICOS DA CONSTRUÇÃO DO CÓDIGO CIVIL DE FAMÍLIA BRASILEIRO

"Visto que nossa vida começa e termina com a necessidade de cuidados, não seria sensato praticarmos a compaixão e o amor ao próximo enquanto podemos?"

Dalai Lama 


\section{A PRAXIS DO CÓDIGO DE FAMÍLIA BRASILEIRO}

\subsection{FUNDAMENTOS PRÁTICOS DE CONSTRUÇÃO DO CÓDIGO DE FAMÍLIA BRASILEIRO}

O desenvolvimento da construção dos fundamentos do Código de Família brasileiro foi organizado em dois planos. Na primeira parte, foram desenvolvidos os fundamentos teóricos e, na segunda parte, passa-se ao desenvolvimento dos fundamentos práticos para dar eficácia à codificação especializada para acolher os conflitos de família, dando condições para a efetiva realização da proteção do Estado, insculpida no artigo 226 da Constituição Federal.

Para fazer a mediação entre a teoria e a prática, ou, ainda, entre a primeira e a segunda parte, é preciso, desde logo, compreender a orientação dada para o desenvolvimento principiológico e paradigmático da teoria do qual se extraem os seguintes pilares:

a) o Direito de Família conquistou uma estatura de tanta importância e visibilidade, que requer espaço para criar mecanismos capazes de ampliar suas potencialidades, o que é impossível no âmbito do Código Civil;

b) a ampliação dessas potencialidades realizam-se pela interdisciplinaridade, na construção de um conhecimento transdisciplinar, com uma visão completamente aberta, pois ela ultrapassa o domínio das ciências exatas, pelo seu diálogo e sua reconciliação, não somente com as ciências humanas, mas também com a arte, a literatura, a poesia e a experiência interior, enfim, o revival; 
c) o fenômeno de emancipação do Direito de Família foi propiciado pelos paradigmas da pós-modernidade, num movimento de rotação, deslocando o olhar do Direito, que repousava numa visão positivista e materialista de se realizar - o que se refletiu em categorias humanas de excluídos e incluídos, em relação ao poder do capital para privilegiar a vida, em sua plenitude, expressando-se em sua mais alta manifestação biológica: o ser humano;

d) há reconhecimento de um Direito pós-moderno que só pode se realizar pela ética do cuidado, pelo princípio da dignidade da pessoa humana e sua concretização em qualidade de vida, sendo fortemente valorada a intuição, ferramenta indispensável para o acesso à justiça;

e) o conflito de família merece ser reparado, e não julgado, de acordo com o paradigma de inclusão e não de exclusão e ruptura, impondo-se compreender que todo conflito humano é indivisível e único;

f) não há conflito genuinamente parental, mas é sempre decorrente de conflito conjugal, havendo na família uma mudança de funções e papéis que demandam oportunidade de reorganização;

g) o Direito de Família pós-moderno está centrado na relação de afeto entre duas pessoas, e não mais na lei ou no juiz, paradigmas já superados.

A eficácia destes fundamentos teóricos em plena realização prática exige um Código que contenha princípios descritos pela narrativa, para serem aplicados por profissionais especialmente formados para esta arte, em uma organização de Direito Quântico. 


\subsection{DIREITO QUÂNTICO}

Ao longo da construção dos fundamentos teóricos e práticos do Código de Família brasileiro, houve várias menções à insistência de Jean Carbonnier ${ }^{187}$ em exaltar que há relacionamento indissociável entre o Direito e os avanços das ciências, em especial as ciências biológicas, refletindo-se nas mudanças paradigmáticas ocorridas ao longo da história, com ênfase no Direito de Família.

A expressão desta assertiva, escolhida pelo civilista, é "le droit saisi par la biologie", isto é, o Direito e a Biologia estão vinculados, tangenciados, pela lei da ordem do universo: o biológico - a vida - precede o Direito, e este, em conseqüência, decorre da Biologia $^{188}$.

A demonstração de que a lei da ordem do universo insere-se no conhecimento do Direito como práxis vem de uma contribuição de envergadura incontestável, sustentada por Goffredo Telles Júnior, assegurando que o Direito é quântico, posto que situado no mundo ético, em um estágio da natureza única ${ }^{189}$ :

“A ordenação jurídica é a própria ordenação universal: é a
ordenação universal no setor humano, a ordenação da natureza
única, no setor em que é promovida a ordenação cultural. A Teoria
Quântica do Direito, o Quantismo Jurídico, é a tese de que o
Direito insere-se na Harmonia do Universo - do 'unum versus

${ }^{187}$ CARBONNIER, Jean. Droit civil, t. 2, p. 33.

${ }^{188}$ CARBONNIER, Jean. Droit civil, t. 2, p. 33.

189 TELLES JUNIOR, Goffredo. Direito quântico. 7. ed. São Paulo: Editora Juarez de Oliveira, 2003, em Nota Preliminar, p. XI, à guisa de prefácio. A primeira edição desta obra - publicada em 1970 representa uma revolução no ambiente jurídico brasileiro, surpreendido com um livro de Direito, que dedica 140 páginas para descrever o universo e a eclosão da vida, nome dado ao primeiro capítulo. $\mathrm{O}$ Professor Goffredo Telles Júnior anunciava a mudança de paradigma do Direito saisi pela descoberta da molécula do DNA, revelada em 1953, que não sensibilizou os juristas positivistas e unidisciplinares, ainda sob influência do paradigma da modernidade. 


\begin{abstract}
alia': do Uno feito do diverso - e, ao mesmo tempo, dela emerge, como requintada elaboração do mais evoluído dos seres ${ }^{190 "}$,
\end{abstract}

O Direito Quântico retrata um conhecimento interdisciplinar, de uma elaboração do Direito, da Física moderna e da nova Biologia, levando a novas descobertas acerca da natureza da vida. Estas infinitas possibilidades são a visão pós-moderna de mundo ${ }^{191}$.

Sendo a vida o bem maior a merecer a proteção do Direito, cabe a este extrair as suas leis, seguindo a ordem biológica da vida. Assim, o Código de Família Brasileiro deverá proporcionar a oportunidade de restabelecer a plenitude da vida como ideal de proteção do Estado.

${ }^{190}$ Para compreender a importância do relacionamento da biologia com o Direito, foi necessário admitir a interdisciplinaridade para uma nova construção do conhecimento jurídico, e o autor é um lídimo representante brasileiro desta avançada visão, numa atitude evidentemente pós-moderna. A obra encontrou acolhida entre os professores de biologia e física da USP, que, depois de muitas reuniões e colóquios, declararam ao Professor, conforme seu relato, que: "Para minha alegria aqueles mestres foram unânimes na declaração de que meu modesto trabalho havia posto à mostra uma realidade ainda não devidamente evidenciada: a de que a liberdade e a disciplina no comportamento humano dependem, em parte considerável, das mensagens emitidas pelo DNA, sediado no núcleo das células. Meu artigo (publicado na Revista Brasileira de Filosofia em 1970), disseram eles, revelara a "ponte" entre a Biologia e o Direito".

191 A física quântica é um conhecimento que tem sido objeto de ampla divulgação como compreensão do comportamento humano, e não apenas como conhecimento teórico, com linguagem hermética, portanto destinado a poucos. O exemplo deste fato é o sucesso mundial do filme de longa metragem Quem Somos Nós? (título original: What the bleep we do now?), em forma de documentário, com participação de físicos, teólogos, biólogos, filósofos etc., dando depoimentos acerca do tema. Em síntese, o filme demonstra que a física quântica calcula possibilidades e o pensamento humano escolhe uma delas, tornando-a real. O materialismo moderno e a religião deslocam as pessoas da necessidade de se sentirem responsáveis por suas vidas. Já a mecânica quântica demonstra que crenças, pensamentos e emoções criam reações químicas que sustentam a vida. Transcrição extraída do filme: "Na verdade a maior parte do universo está vazia. Gostamos de imaginar o espaço vazio e a matéria sólida, mas, na verdade, não tem nada na matéria, ela não possui substância! Veja um átomo. Pensamos que é uma bola sólida. Mas na verdade é esse pontinho pequeno com matéria densa no centro, cercado por uma nuvem de elétrons que aparecem e desaparecem. Mas acontece que tal descrição também não está correta. Até o núcleo, que pensávamos ser tão denso, aparece e desaparece assim como os elétrons. A coisa mais sólida que pode existir nessa matéria desprovida de substância é um pensamento, um bit de informação concentrada. $\mathrm{O}$ que faz as coisas são idéias, conceitos e informação". "Em vez de pensarmos nas coisas como possibilidades, temos o hábito de pensar que as coisas que nos cercam já são objetos que existem sem a minha contribuição, sem a minha escolha. Você precisa banir essa forma de pensar; tem que reconhecer que até o mundo material que nos cerca - as cadeiras, as mesas, as salas, os tapetes - não são nada além de possíveis movimentos de consciência. E eu estou escolhendo momentos nesses movimentos para manifestar minha experiência atual. É algo radical que precisamos compreender, mas é muito difícil, pois achamos que o mundo já existe independente da minha consciência". Enfím, a mecânica quântica devolve ao humano a possibilidade de intervir no mundo, tornando-se potente para criar um mundo de acordo com seus pensamentos e sentimentos: única certeza real. Assim, o ser humano sente-se responsável por suas escolhas. O paradigma da modernidade era: "penso, logo existo". O paradigma da física quântica é: "escolho, logo sou”. Eis a mudança de comportamento com a visão do mundo das possibilidades infinitas. 
Em outras palavras, o que se está a dizer é que a lei da ordem da Física e da Biologia, da qual decorre o Direito, viabiliza a realização e a concretização do princípio da dignidade da pessoa humana.

O jurisdicionado brasileiro merece um movimento de amplo acesso à justiça, quando sujeito de conflito familiar. Os fundamentos práticos para realizar os fundamentos teóricos são: juízo universal, princípio da oralidade e mediação familiar interdisciplinar.

\subsection{PRINCÍPIO DA ORALIDADE}

É instrumento da práxis do Código de Família brasileiro o preponderante uso do princípio da oralidade nos processos que envolvem conflito de família, dada a peculiar natureza das relações familiares. Para que haja a humanização do Direito de Família, é preciso organizar os procedimentos a ele relativos, dando importância a este princípio, visando oferecer meios para que o jurisdicionado possa tomar a palavra, com a merecida valorização outorgada pela ética do cuidado, concretizando-a.

A prestação jurisdicional para conflitos familiares, os mais complexos de todos, porquanto sejam eles os mais desgastantes, pois envolvem sofrimento e afeto, só se realizará se houver um aparelhamento com recursos humanos sofisticados, com o aprimoramento do sistema. A atividade do Estado, pela escuta e pela predominância do princípio da oralidade, bem conduzido, com sentido e sentimento, poderá promover a restauração do desvio de função no sistema familiar, origem de todos os conflitos que chegam ao Judiciário.

A ética do cuidado é a atividade humana da preservação da vida e, em conseqüência, da dignidade da pessoa humana. E o princípio da oralidade é a ferramenta adequada, o instrumento processual para dizer o direito - júris + dição. 
O princípio da oralidade é a mais antiga manifestação do sujeito de direito, mesmo antes da organização do conhecimento do Direito como sistema. Quando é dada ao jurisdicionado a oportunidade de ser acolhido pelo Judiciário, este representado pelo juiz investido dessa função, manifesta seu desejo atávico de falar e ser ouvido, enfim, deseja tomar a palavra ${ }^{192}$.

Daí os atos processuais serem em forma de audiência, oitiva, sustentação oral, ou seja, são manifestações humanas que envolvem o aparelho fonador como meio de concretização deste princípio.

A linguagem oral é a mais antiga forma de comunicação humana, pois a linguagem escrita é recente na história da humanidade, possível apenas com a teoria do signo e com a invenção do papel.

O Direito Romano organizou-se, ao longo de mais de mil anos de história, tendo as formas orais como único meio de realização dos atos processuais. Desenvolveram uma verdadeira liturgia ${ }^{193}$, com formalidades expressas por palavras que continham poder de criar direitos perpétuos, como se fossem gravados em pedra - lithos - constituindo fórmulas rígidas e imutáveis.

Jefferson Carús Guedes ${ }^{194}$ ressalta:

${ }^{192}$ Na prática forense, é freqüente ouvir a parte perguntar ao advogado se ele pode falar ao juiz, ou então, quer manifestar sua expressão oral pela voz das testemunhas. O leigo estranha quando seu advogado não fala em audiência, pois, se sente mal representado, sem voz, como se não the tenha sido dada a palavra. Há uma inversão histórica na origem do processo - com predominância da oralidade - pois, nos tempos atuais, predomina a escrita, o que não corresponde à fala humana, na qual a palavra tem natureza criativa.

${ }^{193}$ SILVEIRA BUENO, Francisco da. Grande dicionário etimológico-prosódico da língua portuguesa, p. 2.200 - Liturgia - gr. lithos pedra, lat. liturgia. Estudo dos ritos sagrados da igreja. Conjunto das cerimônias do culto católico. No início da igreja cristã, designava especialmente o culto, as cerimônias da eucaristia depois da missa, e, finalmente, todos os ritos sagrados. No paganismo grego, queria significar o conjunto de atos necessários para os trabalhos públicos, espécie de burocracia moderna. Sugiro as abreviaturas em amarelo por extenso.

${ }^{194}$ CARÚS GUEDES, Jefferson. O princípio da oralidade. procedimento por audiências no direito processual civil brasileiro. São Paulo: RT 2003. p. 19. 
"Legis actionis ou ações de lei são as formas procedimentais e rituais surgidas da praxe, que consistiam em fórmulas orais pelas quais se iniciava o procedimento contencioso, dirigido à demonstração ou à execução de um direito. A essência residia na recitação solene das fórmulas verbais correspondentes a cada direito. Nas cinco legis actiones: pignoris capio, manus iniectio, sacramentum in rem, conditio e iudicis postulacio, está presente a oralidade, como na última, na qual a parte recitava 'peço ao pretor que me dê um juiz ou árbitro’ em estreita e rigorosa repetição".

Com a invenção do papel, o processo escrito foi tomando certo espaço do processo oral, mas os atos processuais escritos eram realizados pela linguagem oral, a exemplo da sentença, prolatada por escrito, que dependia de ser lida para ter eficácia.

A importância da retomada ontológica do princípio da oralidade, nesse contexto, é para dar ênfase à necessidade de predominância da oralidade sobre a forma escrita no processo de família, dada a importância da fala e da palavra humanas.

Conforme já exposto em capítulo anterior, com a compreensão do valor da palavra e da fala, é possível entender o poder do princípio da oralidade como instrumento jurídico e, assim, a sua importância como meio integrativo do conjunto principiológico orientador do Direito de Família.

A pureza desse princípio deve ser observada também pelos profissionais investidos de concretizar a proteção do Estado, em especial o juiz, cujo valor simbólico no imaginário do jurisdicionado deve ser conhecido, para aproveitamento do importante tempo-espaço dedicado à realização da audiência.

Para o adequado exercício do princípio da oralidade com o propósito reparador para os conflitos de família, é necessário que haja uma reestruturação no sistema, 
principalmente na magistratura, pois, na atual condição, é impossível obter os resultados alvissareiros de qualidade de acesso à justiça, nos moldes do ideal da ética do cuidado, do princípio da dignidade da pessoa humana, para atingir a máxima do princípio da proteção do Estado, em sua plenitude paradigmática e principiológica.

Em juízo de família, é raro encontrar mecanismos adequados à prática do princípio da dignidade da pessoa humana, este existente, efetivamente, apenas como ideal inserto na Constituição Federal.

E não é só em relação aos jurisdicionados, esta falta de mecanismo de viabilização capaz de concretizar a dignidade, mas também em relação ao exercício profissional dos próprios advogados, juízes e promotores de justiça, os quais não dispõem de acomodações mínimas para a garantia da privacidade, para a escuta das partes, em audiência, com tempo adequado para os atos.

Renato Nalini narra como magistrado o drama do exercício da profissão:

"O Judiciário trabalha de forma empírica, sufocado pelo acúmulo de serviço e perplexo diante das adversidades postas qual empecilho ao cumprimento de sua missão constitucional. $\mathrm{O}$ segredo é investir em eficiência, em multiplicar a capacitação produtiva, em reciclar, em recrutar melhor. Outros países têm apostado na necessidade de uma formação integral e contínua para seus juizes. O juiz não vocacionado é uma fonte autônoma de injustiças. $\mathrm{O}$ trabalho judicial angustia e somente pessoas equilibradas e devidamente preparadas conseguem se desvencilhar dele sem multiplicar os conflitos ou comprometer a própria higidez mental." 195 (grifo nosso)

195 NALINI, Renato. Partir do Zero. O Estado de S.Paulo, São Paulo, 03 jan. 2003. Caderno A2, p. 2. O autor é Desembargador do Tribunal de Justiça de São Paulo, como juiz de carreira desde 1976, professor de Filosofia do Direito na USP e na PUC e membro da Academia Paulista de Letras. Tem autoridade intelectual e técnica para avaliar os problemas do Judiciário, portanto este depoimento é uma fonte 
A frase em destaque - o juiz não vocacionado é uma fonte autônoma de injustiças é o primeiro passo para viabilizar a prática do Código de Família. É indispensável que o juiz seja vocacionado para a escuta e para lidar com o sofrimento humano. Afinal, o jurisdicionado em crise e, na maioria das vezes, em sofrimento, vai ao Judiciário em busca do cuidado assegurado pelo Estado, visando à retomada da capacidade de se responsabilizar por suas escolhas.

O preparo das condições adequadas para a consagração do princípio da oralidade exige o juízo universal para as demandas que envolvem relações de afeto.

\subsection{JUÍZO UNIVERSAL}

Os fundamentos práticos do Código de Família Brasileiro organizam-se com o norte voltado à lei da ordem da vida, que precede o Direito, na conformidade do Direito Quântico, este como instrumento de concretização do princípio da proteção do Estado, de natureza constitucional, que visa à proteção da vida humana, integrando a família.

Para Leonardo Boff, esta prática se dá porque a

"vida é algo que nós não produzimos, mas acolhemos. É um fenômeno que emerge de forma misteriosa dentro da criação (...) Acolhe, cria continuamente, auto-organiza-se e controla e sintetiza todos os dados assimilados. É a vida como autopoiesis (autocriação e auto-organização) da própria matéria, como falam tantos biólogos contemporâneos"

preciosa que sinaliza um caminho para o aprimoramento do acesso à justiça, servindo de norte para colher os fundamentos práticos para o Código de Família brasileiro.

196 BOFF, Leonardo. A voz do arco-íris, p. 53. 
A vida é una porque é acolhida da unidade, do princípio, e deve reconhecer a família como unidade, assim como o conflito familiar como expressão desta unidade, como reflexo do sistema familiar.

Goffredo Telles Junior fundamenta esta unidade:

"Envolvendo o mundo com um novo olhar, somos levados a concluir, em síntese, que proviemos de um Princípio Único, de um só Princípio Inicial, que não saberemos nunca definir e situar, mas cuja negação nos levaria à contradição de negar a nossa própria existência" 197.

O conflito é uno, pois é de natureza relacional, portanto a família está envolvida ativa ou passivamente, e a jurisdição do Estado para os conflitos de família tem de ser uno e só pode se esgotar quando o jurisdicionado tiver a reorganização do sistema - autopoiesis - para retornar à ordem natural possível para aquele núcleo, retomando papéis e funções.

No entanto, a realização da proteção do Estado só se legitima se expressar esta unidade, impondo-se, assim, a universalidade do juízo especializado para cuidar dos conflitos de família.

O juízo de família deve ser universal e o representante do Estado deve ter uma formação universal - interdisciplinar - para compreender e dialogar com o ser universal, portador de toda a humanidade em si, expressa na dignidade da pessoa humana, como expressa Edelman:

197 TELLES JUNIOR, Goffredo. Ética: do mundo das células ao mundo dos valores. 2. ed. São Paulo: Editora Juarez de Oliveira, 2004. p. 277. 
"todos os seres humanos compõem a Humanidade, que se apresenta como a reunião simbólica de todos os homens naquilo que eles têm de comum - a qualidade de seres humanos - permitindo o reconhecimento de uma pertença a um mesmo gênero: o gênero humano. A dignidade é a qualidade dessa pertença. Se a liberdade é a essência dos direitos humanos, a dignidade é a essência da humanidade". 198

Portanto, é inconcebível o sistema atual que impõe um critério antinatural de estabelecimento de competência para os conflitos familiares, fracionando a humanidade do jurisdicionado e a própria humanidade do juiz, quando se apresenta como Estado, como unidade, porém incapacitado para ser universal, de acordo com o princípio da lei biológica, a lei da vida.

É bastante freqüente deparar-se com famílias que se tornam vítimas do sistema, quando recorrem ao Judiciário, em uma relação de litígio. São seres universais em seu princípio e buscam o Estado universal, cujo sentido é a proteção ao livre desenvolvimento da personalidade pela ética do cuidado, mas recebem um tratamento fracionado, orientado por paradigmas há muito abandonados, porque atentam contra a própria dignidade do jurisdicionado e do Estado.

Um exemplo típico da prática jurídica de família é a execução de alimentos, com ações propostas periodicamente, dada a contínua inadimplência advinda de outras causas, não investigadas, por desconhecimento e limitação disciplinar. A distribuição é livre, diversificando juiz e vara, pelo que há uma grande variedade de procedimentos, de acordo com o estilo da vara: pode haver designação de audiência de tentativa de conciliação, ou a determinação de penhora ou prisão, sem que o juiz se relacione com o resto das partes, ou os longos processos em que nada acontece e a partes esgotam-se pelo decurso do tempo.

${ }^{198}$ EDELMAN, Bernard. La dignité de la personne humaine, un concept nouveau. In: PAVIA, Marie Luce; REVET, Thierry (Org.). La dignité de la personne humaine. Paris: Economica, 1999. p. 28. 
Normalmente, as execuções de alimentos são seguidas de uma ação revisional ou de mudança de guarda, promovidas pelo devedor de alimentos, seja para reduzir a obrigação, seja para se eximir de pagar alimentos, com a inversão da guarda. Tais ações também são distribuídas pelo critério de distribuição livre, e não por dependência. $O$ resultado é que cada um dos juízes só conhece a demanda que está em sua jurisdição. Tratam a questão como se fosse universal, invertendo a ordem da vida.

Não há uma atitude que contemple o conflito familiar em sua inteireza, oriundo de um sistema que só existe enquanto houver, no mínimo, duas pessoas, para haver uma relação, com o exercício de funções e papéis.

Este tratamento ao jurisdicionado é uma afronta à dignidade da pessoa humana e ausente completamente à proteção do Estado.

Impõe-se estabelecer aos conflitos familiares o critério do juízo universal, para que um só juiz tenha o conhecimento e a devida intimidade com os membros da família e com as diversas formas de manifestação do mesmo conflito.

A fundamentação processual do juízo universal para conflitos familiares toma por empréstimo a experiência do juízo da falência.

Doutrinando sobre o tema, Nelson Nery Junior afirma:

"Diz-se indivisível o juízo da falência porque ele atrai todas as ações e questões atinentes aos bens, interesses e negócio da falida. Todas juntas formam o procedimento falimentar. Diz-se ser o juízo universal porque para ele concorrem todos os credores do devedor, civis e comerciais. (...) A unidade do juízo falimentar tem natureza coletiva, assegurando que todos os credores devem ser tratados com igualdade em relação aos demais credores da mesma 
categoria. Somente a unidade e a universalidade do juízo poderiam assegurar a realização dessas regras"

O conceito apreendido é a natureza de unicidade, indivisibilidade e universalidade. A indivisibilidade da competência manifesta-se por duas características: ser absorvente e ser atrativa. Isto implica seu caráter unitário, quer dizer, só pode haver um único juízo falimentar para um mesmo devedor.

Estes princípios foram mantidos na nova Lei de Falências e de Recuperação Judicial e extrajudicial da Lei n. 11.101/2005. Aliás, a nova denominação da lei atribui ao Estado a função de recuperação do sistema, portanto identifica-se aí a orientação paradigmática pós-moderna, pois assegura o cuidado para a manutenção da vida do sistema.

Na França, embora não haja competência de juízo universal, há um comportamento dos juízes que supre a falta do procedimento. Ao sentenciar, o juiz recolhe informações de todas as medidas judiciais que envolvem a família, para constar da sentença, em uma composição biográfica do comportamento repetitivo, de conflito familiar.

Assim, o julgamento contextualiza o processo, em um movimento de integração de todas as medidas judiciais, reconhecendo que se trata de um só litígio ${ }^{200}$.

${ }^{199}$ NERY JUNIOR, Nelson; NERY, Rosa Maria Andrade. Código de Processo Civil comentado e legislação. 3. ed. São Paulo: Editora dos Tribunais, 2004.

${ }^{200}$ BARBOSA, Águida Arruda. Alcance da mediação familiar: uma sentença paradigmática. In: HIRONAKA, Giselda Maria Fernandes Novaes (Coord.). A outra face do Poder Judiciário. Belo Horizonte: Del Rey, 2005. p. 513-528. Uma sentença paradigmática francesa serve de exemplo para a criação de um sistema de juízo universal no Brasil. São dez anos de processos intermináveis, como relata a sentença: "Por sentença datada de 9 de setembro de 1988, o Juiz dos Feitos Matrimoniais decidiu que os pais exerceriam em comum a autoridade parental sobre o filho Jean, e fixou a residência da criança no domicílio de seu pai, proibindo a mãe de sair com a filha do território nacional. (França). Por sentença, datada de 15 de junho de 1993, o Juiz dos Feitos Matrimoniais decidiu que os pais exerceriam em comum a autoridade parental sobre os dois filhos, Jean e George, fixando a residência de Jean com seu pai e a de George com sua mãe, convidando as partes a recorrerem a uma Mediação Familiar, a fim de buscar uma solução que permitisse aos filhos verem livremente ambos os pais, apesar das fronteiras. Por sentença, datada de 15 de fevereiro de 1994, o Juiz dos Feitos da Família fixou a residência de Jean com sua mãe, mantida a autoridade parental conjunta, e organizou o direito de visita atribuído ao pai em relação às duas crianças: a cada ano, de 1 a 30 de julho, e posteriormente, no inverno da França (verão no Brasil), de 20 de dezembro a 31 de janeiro para o primeiro ano, depois de 1 de janeiro a 31 de janeiro para o segundo 
As lides de família terão um grande ganho quando forem regidas pelo critério de competência do juízo universal, de forma a atrair todas as ações para o juízo prevento pela primeira distribuição.

O profissional que atuar em procedimentos desta natureza terá o dever de ampliar o conhecimento em busca da compreensão do Direito de Família na ótica interdisciplinar para entender esta unidade do conflito familiar, e, por sua natureza, pode vir a expressarse em diferentes relações, às vezes, recai sobre alimentos, depois se desloca para regime de visitas, em outro tempo, volta a expressar-se na forma de revisional de alimentos.

A implantação, portanto, do juízo universal para a fixação de competência ratione materiae é um critério que valoriza o conflito familiar como um sistema vivo em vez de apequenar o conflito de família, ao tratá-lo apenas como lide. A conseqüência dessa mudança é que a prestação jurisdicional passa a ter outra natureza jurídica, qual seja, a reparadora.

Para aplicar, porém, as forças do Direito Quântico, cujo sentido é a lei da ordem biológica, estabelecendo um sistema de escuta para dar a devida importância ao princípio da oralidade, organizando-se um juízo universal para recepcionar a universalidade da dignidade da pessoa humana, é preciso ter ferramenta adequada: a mediação familiar interdisciplinar.

ano, e assim por diante, alternativamente. A Corte de Apelação confirmou esta decisão em acórdão proferido em 5 de julho de 1994. Por sentença, datada de 13 de dezembro de 1994, o Juiz dos Feitos da Família confiou somente à mãe o exercício da autoridade parental sobre as duas crianças, e suprimiu o direito de visita em favor do pai, em virtude de Pierre ter desaparecido com Jean, após a decisão que atribuiu a guarda da criança à mãe Após a prisão de Pierre em fevereiro de 1996, Jean foi entregue a sua mãe. Em petição datada de 24 de setembro de 1996, Pierre requereu ao Juiz dos Feitos da Família a fixação do exercício conjunto da autoridade parental, sobre as duas crianças, e a organização do direito de visita, num primeiro tempo, e, após, a fixação da residência das crianças com o requerente. Por sentença de 15 de abril de 1997, o Juiz dos Feitos da Família declarou-se competente, para ...”. 


\subsection{MEDIAÇÃO FAMILIAR INTERDISCIPLINAR}

Para apresentar a mediação familiar interdisciplinar, ninguém melhor que Jean Carbonnier: "A ambigüidade plaina sobre a mediação, esta filha putativa da pósmodernidade moderna: de esquerda, porque é justiça popular; de direita, porque um juiz do Estado poderia ser, para os fracos, um protetor" ${ }^{\prime 201}$.

A mediação familiar interdisciplinar é expressão da pós-modernidade e começa a ser reconhecida como preciosa ferramenta para o Direito de Família, por ser instrumento de linguagem própria para viabilizar o aprimoramento do princípio da oralidade e, conseqüentemente, dar eficácia ao sentido de que se imprime com o princípio do juízo universal para determinação de competência dos processos de família.

É justamente na alvissareira década de 1960 que a mediação renasce, agora no Ocidente, pois no Oriente ela sempre esteve viva. Nessa década de tantos acontecimentos históricos e libertários, os quais ofereceram caminhos de encontro de melhor qualidade de vida, em decorrência do pós-guerra, pós-nazismo, enfim, eclodia a pós-modernidade.

O princípio da dignidade da pessoa humana começava a ser recepcionado por constituições européias, a exemplo da Itália e da Alemanha, o anticoncepcional hormonal mudava o comportamento das mulheres; no ano de 1968, os estudantes reivindicaram o direito de escolha do conteúdo das disciplinas, para não serem manipulados, e o já mencionado musical Hair, trazia uma campanha de liberação sexual.

A época referida é também o marco da interdisciplinaridade, a exemplo de obras clássicas de Jean Carbonnier, relacionando Direito e Sociologia, e a obra em estudo neste capítulo, Direito Quântico, do jurista interdisciplinar Goffredo Telles Junior, relacionando Direito, Física e Biologia.

${ }^{201}$ CARBONNIER, Jean. Sociologie juridique, p. 147. 
É neste cenário que acontece a explosão da mediação nos Estados Unidos, para desafogar o Judiciário, estando muito mais próximo da conciliação, de acordo com a cultura e as peculiaridades daquele país. Canadá e França desenvolvem o conceito e constroem os fundamentos teóricos do conhecimento da mediação e de seu método de atuação, atribuindo ao instituto a estatura de princípio, de comportamento.

A mediação é um método que se vale de técnicas de comunicação, adequada para a escuta qualificada, prestando-se, com muita eficácia, a concretizar o princípio constitucional de proteção à dignidade da pessoa humana e de proteção do Estado. Como se trata de uma linguagem, qualquer profissional pode se habilitar para obter uma formação.

Com a mediação, as ciências humanas fazem irrupção nas relações jurídicas, pois se trata de um conhecimento interdisciplinar a serviço do acesso à justiça, assim, os saberes das diferentes disciplinas - direito, psicanálise, psicologia, sociologia, filosofia etc. conduzem a uma complementaridade da prática social, função e objetivo desta nobre linguagem, permitindo implementar os paradigmas da pós-modernidade.

$\mathrm{Na}$ comunidade européia, consolidou-se o conceito de mediação como um princípio ético, um comportamento humano. Assim, a definição de mediação ${ }^{202}$ elaborada na conformidade do estágio de evolução em que se está é a seguinte:

\footnotetext{
“A mediação é um processo de criação e de repartição do vínculo social e de regramento dos conflitos da vida cotidiana, na qual um terceiro, imparcial e independente, por meio da organização de trocas entre as pessoas ou instituições, tenta ajudá-los a melhorar uma relação ou regular um conflito que as opõe”.
}

202 SASSIER, Monique. Construire la médiation familiale. Paris: Dunod, 2001. p. 90-93. 
A mediação familiar não é um subtratamento jurídico, como se fosse uma instância menos qualificada tendente a pôr fim ao conflito, para desafogar a atividade jurisdicional, abarrotada de processos, sendo a maioria oriunda dos conflitos familiares. Ela não é uma assistência psicológica das partes, prática profissional com objeto e método próprios da Psicologia, que não pode ser imposta às pessoas em conflito, posto que depende de uma decisão pessoal submeter-se a uma psicoterapia. Trata-se de uma atividade que exige um tempo - meses ou anos - que não se enquadra no tempo do Judiciário, que não tem competência para o exercício de atividades clínicas.

A mediação não é terapia familiar, especialidade terapêutica sistêmica, fundamentada na Escola de Palo-Alto (San Francisco - Estados Unidos), e nos trabalhos de Gregory Bateson, cujo objetivo é a manutenção dos vínculos familiares, portanto não atua na ruptura destes. Registre-se, no entanto, que este ramo do saber deu suporte à construção de alguns modelos de mediação familiar, a exemplo da Argentina.

Para afastar a idéia de soluço de conflitos - próprio da conciliação - a mediação familiar não é uma negociação com o objetivo de "resolver" ou "solucionar" um conflito, atividade técnica própria de jurisdição estatal, como satisfação da pretensão jurisdicional, concedendo a tutela jurídica buscada. Afasta-se, também, completamente, do conceito de arbitragem, na qual as partes em conflito, no exercício da autonomia da vontade, elegem uma terceira pessoa, neutra e imparcial - o árbitro -, autorizando-o a tomar uma decisão que obrigará os envolvidos no conflito.

Há muitos profissionais de carreira jurídica que se qualificam como mediadores, atividade que tem sido promovida pelos Tribunais de Justiça de vários Estados, na busca de acordos, para desafogar o Judiciário. No entanto, há um equívoco delicado a ser esclarecido, pois o conteúdo dessa atividade, normalmente sob a influência do modelo norte-americano que "chamam" de mediação, na verdade é de conciliação, prática que se resume em atividade de reorganização lógica, no tocante aos direitos que cada parte acredita ter, polarizando-os, eliminando os pontos incontroversos, para delimitar o conflito, e, com técnicas normalmente empíricas, o conciliador visa corrigir as percepções distorcidas, aproximando as partes em um espaço concreto. Nesta técnica, os litigantes 
reafirmam sua incapacidade de resolver naturalmente sua controvérsia, necessitando de pessoa externa à relação, conduzindo-os à negação do conflito.

A Mediação familiar ${ }^{203}$ é um método fundamentado, teórica e tecnicamente, por meio do qual uma terceira pessoa, neutra e especialmente treinada, ensina os mediandos a despertarem seus recursos pessoais para que consigam transformar o conflito. Esta definição advém da ótica da técnica da comunicação.

O primeiro passo para dar eficácia ao Código de Família Brasileiro é a ampla formação dos profissionais jurídicos em mediação familiar interdisciplinar, que tem como fundamento e objetivo a comunicação humana.

Um juiz, que tenha esta formação, com conhecimento das dinâmicas familiares e do conflito humano estará apto para a compreensão da lei da ordem da vida, em sua plenitude, pois ela é o ser humano.

Mediar é a ação de comunicar: informar e informar-se, conhecer e conhecer-se, explicar e explicar-se, compreender e compreender-se. Ressalte-se, porém, que para a mediação familiar a discriminação das diversas formas de comunicação otimiza o nível da compreensão e o da intercompreensão, sendo este último o verdadeiro objetivo a ser alcançado na mediação familiar.

O caminho a ser percorrido para atingir o nível da intercompreensão começa pela qualificada troca de informações, comunicação normalmente deteriorada, já que, inconscientemente, os mediandos comunicam-se pela linguagem do conflito - inadequada e destrutiva - em lugar da linguagem adequada e construtiva da intercompreensão, pois estão tão frágeis, que não conseguem despertar outros recursos pessoais mais adequados.

203 BARBOSA, Águida Arruda. Mediação familiar: instrumento transdisciplinar em prol da transformação dos conflitos decorrentes das relações jurídicas controversas. 2003. 135f. Dissertação (Mestrado) Faculdade de Direito da Universidade de São Paulo, Universidade de São Paulo, São Paulo. 
O mediador dá a palavra aos mediandos, organizando a ordem de uso e o tempo a ser concedido para cada um falar, com a regra rígida de um não interromper a fala do outro. Ao término da fala de cada mediando, o mediador vai repetir, reformular e confirmar a informação, procurando situar os fatos no tempo e no espaço. Esta primeira organização comunicacional - que normalmente ocorre nas duas primeiras sessões de mediação - já se presta a conter a angústia dos sujeitos do conflito, permitindo-lhes acessar logo outro nível mais sensível da comunicação.

Para atingir a intercompreensão, será necessário valer-se de informações, sentimentos, idéias, valores, explicações, representações, permitindo a circularidade da subjetividade e da objetividade de cada um. Trata-se, enfim, de uma atitude comunicativa que leva cada mediando a ter o cuidado de se fazer compreender e de se esforçar para compreender o que o outro diz. Trata-se de diálogo pelo registro do $E u$, vindo das experiências vividas, do $T u$, conforme as relações interpessoais, e do Ele, advindo do estado de coisas existentes.

Nesta dinâmica comunicacional, há espaço, inclusive, para surgir a incompreensão - tanto do eu como do tu - afinal, compreender e compreender-se pressupõe aceitar que existem o inexplicável e o desconhecido presentes em ambos os mediandos.

Dessas considerações iniciais depreendem-se duas conclusões significativas: a primeira é que não se pode dizer que há ausência de comunicação na família, pois o que se observa é a presença de uma comunicação inadequada, não cumprindo a circularidade necessária, movimento indispensável para a sua efetividade; a segunda conclusão é que os desentendimentos familiares têm raiz na dificuldade de comunicação, que começa pela dificuldade de identificação dos próprios sentimentos, em decorrência de não conseguirem identificar os papéis que cada um deve desempenhar no sistema familiar.

A comunicação inadequada exalta-se, sobremodo, quando os pais separam-se, principalmente quando a ruptura é litigiosa, pois, enquanto o ex-casal realimenta 
inadequadamente o vínculo "conjugal" por meio da comunicação da linguagem do conflito, os filhos vivem uma situação de abandono diante da dificuldade de diálogo entre os pais. Muitas vezes o conflito se mantém "em nome" da criança, no entanto os filhos ficam sufocados e sem espaço para compreender seu efetivo papel na família, a qual foi transformada pela separação.

Para essas famílias, a mediação possibilita o resgate da comunicação fundada na intercompreensão, permitindo que o ex-casal compreenda que agem e falam em nome próprio - e não em nome dos filhos -, o que lhes permite discriminar as funções da família, compreendendo que é o casal conjugal que se dissolve. O casal parental, porém, deverá se fortalecer para ter continuidade para sempre.

Assim, os pais tornam-se disponíveis para acompanharem o cotidiano dos filhos, dando o devido significado a questões importantes, como a escolaridade, a sexualidade, a sociabilidade etc. Ressalte-se que a mediação interdisciplinar é capaz de proteger os filhos do divórcio de comprometimentos psicológicos e psicossomáticos, tão presentes nas crianças no período pós-separação.

A mediação como comportamento e como método viabilizam a realização dos paradigmas pós-modernos, aprimora a prestação jurisdicional e garante a realização do princípio da proteção do Estado. Esta qualidade do Judiciário corresponde aos quatro valores da doutrina pós-moderna (Erik Jayme): pluralismo de fontes, comunicação, revival e narrativa. 


\section{CONCLUSÕES}

1. Os fundamentos do Código de Família Brasileiro asseguram à família do futuro a plena eficácia do artigo 226 da Constituição Federal, para dar uma compreensão interdisciplinar ao princípio da proteção do Estado, norteados pelos paradigmas pósmodernos e orientados pelo entendimento de que o conflito familiar é natural ao ser humano, como decorrência do livre desenvolvimento da personalidade, com o reconhecimento do afeto como princípio inserto no ordenamento jurídico pátrio.

2. Os fundamentos do Código de Família Brasileiro concretizam-se nos quatro valores da pós-modernidade - pluralismo, comunicação, retours des sentiments, e narração, e esta - a narração - contém os demais valores, pois decorre do impulso de comunicação e de sentimento, orientando a redação do conteúdo e a forma das normas legais acolhedoras de pluralismo de fontes.

3. Pelo enfoque dos quatro valores pós-modernos, a metodologia na elaboração das leis narrará os objetivos e os princípios das normas de família, cujo sentido é reparador e pedagógico, a exemplo do Estatuto da Criança e do Adolescente (ECA), que contém normas narrativas, sem descrição de condutas, estas próprias para comportamentos universais, verdades absolutas, o que fica completamente afastado da doutrina pósmoderna.

4. A eficácia do princípio da proteção do Estado consiste em oferecer uma prestação jurisdicional na conformidade da ética do cuidado, por intermédio de especializado desempenho dos agentes investidos da função de promover o acesso à justiça, cuja atribuição levará em conta a vocação profissional para lidar com o sofrimento 
humano, com uso de método adequado, promovendo a transformação do conflito familiar, ou seja, possibilita ao sujeito de direito a retomada da responsabilidade por suas escolhas, pela percepção do desvio de papéis e funções no contexto do sistema familiar.

5. O Judiciário ocupar-se-á do caso, porque na escala axiológica pós-moderna este está acima da lei e do juiz: a) dos jurisdicionados, às vezes, momentaneamente incapacitados (infantilizados) de tomar a vida em suas próprias mãos, necessitando do Estado paternalista para protegê-lo e para decidir por ele, desde que decorrente de um processo de conscientização e educação, seguindo o conhecimento da dinâmica familiar e do desenvolvimento da personalidade por parte do juiz e do sujeito de direito; b) dos jurisdicionados capazes de receber do Estado a proteção consistente em oportunidade de recuperação dos papéis e funções - efeitos reparadores do princípio da proteção do Estado - se necessário, com a aplicação de medidas restritivas de direitos (afastamento do lar, guarda única), porque aplicável ao caso, desde que narrado ao sujeito de direito o sentido da medida, visando à compreensão do desvio do exercício de papéis e funções, com previsão de retorno das partes, até que estejam capacitados a fazer escolhas adequadas; c) dos jurisdicionados em sofrimento, devido a uma crise familiar, buscando o aparelhamento do Judiciário para o aprimoramento e o fortalecimento da família, nas instâncias de mediação familiar interdisciplinar.

4. O Código de Família Brasileiro humaniza o sujeito de direito de família, com a forte valoração da palavra e da fala, resgatando para qualquer ato jurídico - judicial ou extrajudicial - o princípio da oralidade, com predominância sobre a forma escrita, que deverá ocorrer com a participação dinâmica dos sujeitos do conflito.

5. Para assegurar a práxis dos fundamentos teóricos do Código de Família Brasileiro, dando vigor ao princípio da dignidade da pessoa humana à ética do cuidado do qual decorre o livre desenvolvimento da personalidade e ao princípio da proteção do Estado, o juízo de família será universal, para que o juiz especialmente formado para este mister, com conhecimento interdisciplinar, possa assegurar ao jurisdicionado a visão do conflito familiar de natureza indivisivel e universal, em sua forma integral, afastando o sistema da era positivista, que considerava que cada demanda era um conflito diferente, 
mesmo que ocorresse pela mesma causa e entre os mesmos sujeitos de direito. O Direito de Família pós-moderno só é legítimo se tiver a garantia de eficácia traduzida em oportunidade de aprimoramento do ser humano.

6. O Código de Família Brasileiro conserva, em si, toda a história das legislações anteriores, pois, como pós-moderno, visa à integração do sistema, fortalecendo-o, enfim, promovendo a justaposição do clássico e do novo, em convivência harmônica. O verbo excluir não tem aplicação a este método, pois o verbo fundamental desta codificação é incluir, e, como não reconhece verdade absoluta, a verdade das relações é a única a ser valorada, tornando possível o convívio com as diferenças. A sentença proferida nesta metodologia e nesta orientação axiológica e principiológica não contém julgamento, pois não há culpado e inocente, mas pessoas responsáveis ou não pelo desenvolvimento da personalidade. A decisão será sempre orientada pela narrativa (benjaminiana), contendo procedimentos de autopoiesis (autocriação e auto-organização) sem descrição de condutas, pois cada família é única e diferente de qualquer outra. O juiz só pode dar condutas de sua própria família, comportamentos que só servem de referência para ele próprio.

7. O Código de Família Brasileiro valoriza a vida humana, atribuindo-lhe sentido como sujeito de direito da personalidade na inserção familiar, reconhecendo o método da intuição (Bergson) como ferramenta para a sua aplicação e interpretação, sendo um sistema jurídico flexível capaz de acolher os avanços da ciência, numa relação de interdisciplinaridade. 
8. O Código de Família Brasileiro é atemporal, voltado para um futuro sem limite, porque, na pós-modernidade, o tempo é um valor para ser aproveitado pela "emocionalidade", o revival da alegria de viver, autopoiético, capaz de reconhecer e acolher as mudanças de paradigma trazidas pela ciência, criativamente. Trata-se, ainda, de uma codificação orientada pelo Direito Quântico, de acordo com a realidade evolutiva das conquistas da ciência a nortear o Direito de Família. No terceiro milênio, é o paradigma da física quântica a referência da compreensão da natureza humana, sujeito de direito destinatário da arte da convivência humana, objeto do Direito: a única verdade do universo é o pensamento e o sentimento, que se consolidam no momento da escolha de uma dentre as infinitas possibilidades. A vida só é, ou seja, só se manifesta na relação criativa entre tu e eu. Eis o princípio da afetividade. 


\section{PROPOSIÇÕES}

1. O Código de Família Brasileiro (CFB) destina-se à revogação, à derrogação e à ab-rogação do Livro IV do Código Civil brasileiro. Seu texto originário será reescrito, levando-se em conta a narrativa (benjaminiana), ampliado pela interdisciplinaridade, pelos princípios e fundamentos, pelos paradigmas pós-modernos, numa edificação de justaposição entre o antigo e o novo, numa atitude valorativa de privilegiar o pluralismo das fontes.

2. Ao lado da implantação do $\mathrm{CFB}$, deverá ser organizado um sistema de adaptação profissional - magistratura, advocacia e promotoria de justiça - para atuação na prática de uma codificação com metodologia e conseqüente linguagens próprias, conforme doutrina pós-moderna de prestação jurisdicional, com o propósito de alcançar a excelência de prestar aconselhamento preventivo e reparatório aos jurisdicionados.

3. A implantação do CFB deverá ser acompanhada de uma alteração do critério de atribuição de Varas de Família aos magistrados, pelo que o Tribunal de Justiça deverá inaugurar um sistema de especialização na matéria, priorizando a vocação, sempre que possível, principalmente nas comarcas em que houver pluralidade de juízes na disputa da jurisdição.

4. Recomendação de instalação de câmaras especializadas em Direito de Família em todos os Tribunais de Justiça brasileiros, na conformidade da campanha promovida pelo IBDFAM e aprovada pelo Conselho Nacional de Justiça.

5. Obrigatoriedade de inclusão da disciplina Mediação Familiar em todos os cursos de graduação em Direito, em justaposição à disciplina Direito de Família, 
organizada com teoria e prática de atendimento e escuta interdisciplinar aos alunos do quinto ano da formação, pois já completa a formação na linguagem binária de resolução de conflitos, com prontidão para o aprendizado da linguagem ternária para compreensão do $\mathrm{CFB}$, norteado pela doutrina pós-moderna. 


\section{REFERÊNCIAS}

ALMEIDA PRADO, Lídia. O juiz e a emoção. São Paulo: Milenium, 2003.

AMARAL, Francisco. A descodificação do direito civil brasileiro. Direito e Justiça, Revista da Faculdade de Direito da Universidade Católica Portuguesa, Lisboa, v. 13, 1999.

AMARAL, Francisco. O Código Civil brasileiro e o problema metodológico de sua realização. Do paradigma da aplicação ao paradigma judicativo-decisório. Revista Brasileira de Direito Comparado, Rio de Janeiro, n. 28, 2005.

AMARAL, Francisco. O Código Civil brasileiro e o problema metodológico de sua realização. Do paradigma da aplicação ao paradigma judicativo-decisório. In: Revista de Direito Comparado: Rio de Janeiro, 2005.

AMARAL, Francisco. Racionalidade e sistema no direito civil brasileiro. Revista de Direito Civil, São Paulo, v. 63, 2005.

ARENDT, Hannah. A condição humana. Tradução de Roberto Raposo. Rio de Janeiro: Forense Universitária, 2005.

AZEVEDO, Antonio Junqueira. O direito pós-moderno e a codificação. Revista da Faculdade de Direito, Universidade de São Paulo, São Paulo, v. 94, 1999.

BALMARY, Marie. La divine origine. Dieu n'a pas crée l'homme. Paris: Bernard Grasset, 1993.

BARANGER, Denis. Bentham et la codification. Droits, Revue Française de Théorie, de Philosophie et de Culture Juridiques, Paris, n. 27, p. 17-37, 1998.

BARBOSA, Águida Arruda. A mulher na área jurídica: família. In: AUAD, Sylvia Maria von Atzingen Venturoli (Org.). Mulher: cinco séculos de desenvolvimento na América. Belo Horizonte: O Lutador, 1999. 
BARBOSA, Águida Arruda. Alcance da mediação familiar: uma sentença paradigmática. In: HIRONAKA, Giselda Maria Fernandes Novaes (Coord.). A outra face do Poder Judiciário. Belo Horizonte: Del Rey, 2005.

BARBOSA, Águida Arruda. Mediação familiar: instrumento transdisciplinar em prol da transformação dos conflitos decorrentes das relações jurídicas controversas. 2003. $135 f$. Dissertação (Mestrado) - Faculdade de Direito da Universidade de São Paulo, Universidade de São Paulo, São Paulo.

BARROSO, Luís Roberto. A nova interpretação constitucional: ponderação, direitos fundamentais e relações privadas. 2. ed. Rio de Janeiro: Renovar, 2006.

BARROSO, Luiz Roberto (Organizador). Fundamentos teóricos e filosóficos do novo direito constitucional brasileiro (pós-modernidade, teoria crítica e pós-positivismo). In: $A$ nova interpretação constitucional. 2. ed. Rio de Janeiro: Renovar, 2006. p. 1-48.

BAUDOUIN, Jean-Louis. Préface. In: PEDROT, Philippe (Organizador). Ethique, droit et dignité de la Personne. Paris: Economica, 1999.

BENJAMIN, Walter. Magia e técnica, arte e política. 7. ed. São Paulo: Brasiliense, 1994. p. 198-213.

BÍBLIA SAGRADA. Tradução de João Ferreira de Almeida. Rio de Janeiro: Sociedade Bíblica do Brasil, 1960.

BITTAR, Eduardo C. B. O direito na pós-modernidade. Rio de Janeiro: Forense Universitária, 2005.

BOFF, Leonardo. A voz do arco-íris. Rio de Janeiro: Sextante, 2004.

BOFF, Leonardo. Saber cuidar - Ética do humano - Compaixão pela Terra. 11. ed. Petrópolis: Vozes, 1999.

BORELLA, François. Le concept de dignité de la personne humaine. In: PEDROT, Philippe (Coord.). Éthique, droit et dignité de la personne. Mélanges Christian Bolze. Paris: Editora Economica, 1999. 
BORGES, Roxana Cardoso Brasileiro. Disponibilidade dos direitos de personalidade e autonomia privada. São Paulo: Saraiva, 2005.

BRUNAUD, Edmond. Le juge aux affaires familiales. Paris: Sofiac, 1997.

BUARQUE DE HOLLANDA, Sérgio. Raízes do Brasil. Brasília: Editora UNB, 1963.

CARBONNIER, Jean. Droit civil. 18. ed. Paris: PUF, 1997. t. 2: La famille.

CARBONNIER, Jean. Droit civil. 18. ed. Vendôme: PUF, 1997. t. 2: La famille.

CARBONNIER, Jean. Droit civil: introdution. Paris: PUF, 1999.

CARBONNIER, Jean. Droit et passion du droit sous la $V^{\text {ème }}$ République. Paris: Flamarion, 1996.

CARBONNIER, Jean. Droit et passion du droit sous la v.ème République. França: Flamarion, 1996.

CARBONNIER, Jean. Flexible droit. 8. ed. Paris: EJA, 1995. (Librairie Générale de Droit et de Jurisprudence).

CARBONNIER, Jean. Sociologie juridique. Vendôme, França: PUF, 1994.

CARÚS GUEDES, Jefferson. O princípio da oralidade. Procedimento por audiências no Direito Processual Civil brasileiro. São Paulo: RT, 2003.

CHAUVEAU, Véronique; POIVEY-LECLERQ, Héléne. Le droit de la famille. Paris: Éditions du Seuil, 2001.

CHAUVIERE, Michel; BUSSAT, Virginie. Famille et codification: le périmètre du familial dans la production des normes. Paris: La Documentation Française, 2000.

COELHO, Francisco Pereira; OLIVEIRA, Guilherme de. Curso de direito de família. Coimbra: Coimbra Editora, 2001.

COLARES, Marcos Antônio Paiva. O que há de novo no direito de família? In: PEREIRA, Rodrigo da Cunha (Coord.). A família na travessia do milênio. ANAIS DO II CONGRESSO BRASILEIRO DE DIREITO DE FAMÍLIA. Belo Horizonte: Del Rey, 2000. 
CORNU, Gérard. Droit civil: la famille. 7. ed. Paris: Éditions Montchrestien, EJA, 2001.

CORNU, Gérard. L'art du droit en quête de sagesse. Paris: PUF, 1998.

CORNU, Gérard. Vocabulaire Juridique. Paris: PUF, 2001.

CUNHA, Paulo Ferreira da. O ponto de Arquimedes. Coimbra: Livraria Almedina, 2001.

CUSTEM, Van Chantal. La famille recomposée. Paris: Éditions Èrès, 1998.

DIAS, Maria Berenice. União homossexual: o preconceito e a justiça. Porto Alegre: Livraria do Advogado, 2000.

DIAS, Maria Berenice; CUNHA PEREIRA, Rodrigo da (Coord.). Direito de família e o novo Código Civil. Belo Horizonte: Del Rey, 2001.

DINIZ, Maria Helena. Curso de direito civil brasileiro. São Paulo: Saraiva, 2002. v. 5.

DUPUY, Pierre-Marie. Quarante ans de codification du droit de la responsabilité internationale des Etats: un bilan. Revue Générale de Droit International Public, Paris, v. 107, n. 2, p. 305-348, 2003.

EDELMAN, Bernard. La dignité de la personne humaine, un concept nouveau. In: PAVIA, Marie Luce; REVET, Thierry (Org.). La dignité de la personne humaine. Paris: Economica, 1999.

ENRIQUEZ, Eugène (Org.). Le for intérieur. Paris: PUF, 1995 (obra coletiva).

FACHIN, Edson Luiz. Direito de família. Elementos críticos à luz do novo Código Civil brasileiro. In: LIRA, Ricardo Pereira (Coord.). 2. ed. Rio de Janeiro: Renovar, 2003.

FACHIN, Luiz Edson. Entrevista. Boletim IBDFAM, n. 19, ano 3, mar./abr. 2003.

FACHIN, Luiz Edson. Le juriste de demain et la connaissance du code civile. Revista de Informação Legislativa, Brasília, n. 162, ano 41, abr.jun. 2004.

FAZENDA, Ivani (Org.). Dicionário em construção: interdisciplinaridade. São Paulo: Cortez, 2002.

FAZENDA, Ivani. Interdisciplinaridade: qual o sentido? São Paulo: Paulus, 2003. 
GANANCIA, Danièle. Justice et médiation familiale: un partenariat au service de la coparentalité. Gazette du Palais, Paris, 7 jul. 1999, p. 2-7 (Tradução de Águida Arruda Barbosa, Giselle Groeninga e Eliana Riberti Nazareth. Revista do Advogado, São Paulo, AASP, n. 62, 1999).

GARCIA BLANCO, Marta. Codification et droit de la post-modernité: la creation du nouveau Code Penal espagnol de 1995. Droit et Societe, Paris, n. 40, 1998.

GELLNER, Ernest André. Pós-modernismo, razão e religião. Lisboa: Piaget, 1994.

GROENINGA, Giselle. Do interesse à criança ao melhor interesse da criança. Contribuições da mediação interdisciplinar. Revista do Advogado, São Paulo: AASP, n. 62, mar. 2001 (Coordenação de Lia Justiniano dos Santos).

GUEDES, Jefferson Carús. O princípio da oralidade. São Paulo: RT, 2003.

GUSDORF, Georges. La parole. Paris: PUF, 1952.

GUY, Stephane. Une utopie: la codification. Revue Française de Droit Constitutionnel, Paris, n. 26, 1996.

HAUSER, Jean; CASEY, Jérôme. Code des personnes et de la famille: Textes: Commentaires: Jurisprudence: Conseils pratiques. Paris: Litec, 2003.

HAUSER, Jean; HUET-WEILLER, Danièle. Traité de droit civil. Paris: Librairie Générale de Droit et de Jurisprudence, 1993.

HIRONAKA, Giselda Maria Fernandes Novaes. Direito civil: estudos. Belo Horizonte: Del Rey, 2000.

HIRONAKA, Giselda Maria Fernandes Novaes. Responsabilidade pressuposta. Belo Horizonte: Del Rey, 2005.

HOOGSTRATEN, M. H. van. La codification par traités in droit international privé dans le cadre de la Conférence de la Haye. Recueil de Cours, La Haye, v. 122, n. III, p. 337-425, 1967.

JAPIASSU, Hilton. Interdisciplinaridade e patologia do saber. Rio de Janeiro: Imago, 1976. 
JAYME, Erik. Visões para uma teoria pós-moderna do direito comparado. Revista dos Tribunais, São Paulo, n. 759, 1999.

JUNG, Karl G. O homem e seus símbolos. Tradução de Maria Lúcia Pinho. Rio de Janeiro: Nova Fronteira, 1974.

KEHL, Maria Rita. Em defesa da família tentacular. In: GROENINGA, Giselle; CUNHA PEREIRA, Rodrigo da (Coord.). Direito de família e psicanálise rumo a uma nova epistemologia. São Paulo: Imago, 2003.

KRISTEVA, Julia. Étrangers à nous-mêmes. França: Librairie Arthème Fayard, 1997.

L'HEURREUX-DURÉ, Claire. L'égalité en droit de la famille; une perspective canadienne. In: POUSSON-PETIT, Jaqueline. Droit Comparé des Personnes et de la Famille. Bruxelas: Ruylant, 1998.

LAFER, Celso. A reconstrução dos direitos humanos. São Paulo: Companhia das Letras, 1988.

LASSERRE KIESOW, Valerie. La codification en Allemagne au XVIII ${ }^{\mathrm{e}}$ siècle. Archives de philosophie du droit, Paris, 1998.

LEITE, Eduardo Oliveira. Famílias monoparentais. São Paulo: RT, 1997.

LEITE, Eduardo Oliveira. Temas de direito de família. São Paulo: RT, 1994.

LÉVESQUE, Justin. Canada: les résultats d'une recherche. Le Groupe Familial, Paris, n. 125, Érès, 1999.

LYOTARD, Jean-François. A condição pós-moderna. 5. ed. São Paulo: José Olímpio, 1988.

MARQUES, Claudia Lima. Visões sobre o teste de paternidade através do exame do DNA em direito brasileiro: direito pós-moderno à descoberta da origem. In: LEITE, Eduardo de Oliveira (Coord.). Grandes temas da atualidade de DNA como meio de prova de filiação. 2. ed. São Paulo: Forense, 2002. 
MARQUES, Claudia Lima; CHAPACUZ, Maria Cláudia; VITÓRIA, Ana Paula da Silva. Igualdade entre os filhos no direito brasileiro atual: direito pós-moderno? Revista dos Tribunais, São Paulo, n. 764, 1999.

MATSUKAWA, Tadaki. La famille et le droit au Japon. Paris: Economica, 1991.

MEULDERS-KLEIN, Marie-Thérèse. Liber amicorum. In: POUSSON-PETIT, Jaqueline (Org.). Droit Comparé des Personnes et de la Famille. Bruxelas: Ruylant, 1998.

MOREUA, Paul. Les valeurs familiales. Paris: Les Éditions du Cerf, 1991.

NALINI, Renato. Partir do Zero. O Estado de S.Paulo, São Paulo, 03 jan. 2003. Caderno A2.

NERY JUNIOR, Nelson; NERY, Rosa Maria Andrade. Código de Processo Civil comentado e legislação. 3. ed. São Paulo: RT, 2004.

NICOLESCU, Basarab. O manifesto da transdisciplina. São Paulo: Coleção Trans, 2001.

NOVAK, Aldo. Coaching. Disponível em: <http:// wikipedia.org>. Acesso em: 12 jan. 2007.

OLIVEIRA, Guilherme. Temas de direito de família. 2. ed. Coimbra: Coimbra Editora, 1999.

OLIVEIRA, Guilherme. Temas de direito de família. Coimbra: Coimbra Editora, 2001.

PAVIA, Marie-Luce. Le décuouverte de la dignité de la personne humaine. In: PAVIA, Marie Luce; REVET, Thierry (Org.). La dignité de la personne humaine. Paris: Economica, 1999.

PEDROT, Philippe. La dignité de la personne: principe consensuel ou valeur incantatoire? In: PEDROT, Philippe (Coord.). Ethique, droit et dignité de la personne. Paris: Economica, 1999.

PELUSO, Antonio Cezar. Direito de família e ciências humanas. São Paulo: Jurídica Brasileira, 1999 (Cadernos de Estudos, n. 1).

PEREIRA, Rodrigo da Cunha. Direito de familia: uma abordagem psicanalítica. 3. ed. Belo Horizonte: Del Rey, 2003. 
PHILLIPE, Adam. A cura pela palavra. Revista Veja, São Paulo: Abril, ed. 1793, 2003. (entrevista - páginas amarelas).

POUSSON-PETIT, Jaqueline. Le personne humaine sur la scène d'un théatre d'ombres. In: POUSSON-PETIT, Jaqueline (Coord.). Droit comparé des personnes et de la famille. Bruxelas: Bruylant, 1998.

RANGEL, Vicente Marotta. Codificação do direito espacial. Revista Brasileira de Direito Aeroespacial, Rio de Janeiro, v. 67, set. 1995.

RANGHETTI, Diva Spezia. Afetividade. In: FAZENDA, Ivani. Dicionário em construção. São Paulo: Cortez, 2002.

RÉMY, Philippe. La recodification civile. Droits, Revue Française de Théorie, de Philosophie et de Culture Juridiques, Paris, n. 26, 1997.

RIBEIRO, Darcy. O povo brasileiro. São Paulo: Companhia das Letras, 1995.

RIZZATTO NUNES, Luiz Antonio. A intuição e o direito: um novo caminho. Belo Horizonte: Del Rey, 1997.

ROUDINESCO, Elisabeth. A família em desordem. Tradução de André Telles. Rio de Janeiro: Zahar, 2003.

ROUDINESCO, Elisabeth. Por que a psicanálise? Rio de Janeiro: Zahar, 2000.

RUBELLIN-DEVICI, Jacqueline. Les grandes réformes en cours dans le droit de la famille en France. In: POUSSON-PETIT, Jaqueline (Org.). Droit Comparé des Personnes et de la Famille. Bruxelas: Ruylant, 1998.

SARMENTO, Daniel. A vinculação dos particulares aos direitos fundamentais no direito comparado no Brasil. In: BARROSO, Luiz Roberto. A nova interpretação constitucional. 2. ed. Rio de Janeiro: Renovar, 2006. p. 193-284.

SASSIER, Monique. Construire la Médiation Familiale. Paris: Editora Dunod, 2001.

SCHIMTT, Carlos Alberto. Concepções e práticas de cuidado humano no cotidiano de uma organização. 2003. Dissertação (Mestrado) - Universidade Federal de Santa Catarina, Santa Catarina. 
SCHUMAN, Robert. Invitation au droit comparé de la famille. In: POUSSON-PETIT, Jaqueline (Org.). Droit Comparé des Personnes et de la Famille. Bruxelas: Ruylant, 1998.

SEGALEN, Martine. Sociologie de la famille. Paris: Masson \& Armand Colin, 1996.

SILVEIRA BUENO, Francisco da. Grande dicionário etimológico-prosódico da língua portuguesa. São Paulo: Lisa, 1998.

SINGLY, François de. Le soi, le coupe et la famille. Paris, Bruxelas: Nathan, 1996.

SINGLY, François de. Problèmes, avec ou sans solution, posés par dix ans. In: SINGLY, François de; MARTIN, Claude; MUXEL, Anne et al. La famille en questions. Paris: Syros, 1996.

SLAKON, C.; DE VITO; GOMES PINTO, R. (Org.). Justiça restaurativa. Brasília-DF: Ministério da Justiça, 2005.

SOARES PEDRO, Antonio Golies. Pai, mãe e filhos. Disponível em: $<$ http://www.uol.com.br>. Acesso em: 21 dez. 2006.

SOURDEL, Dominique. Droit musulmant et codification. Droit, revue française de théorie, de philosophie et de culture juridiques. Paris: Dalloz, 1997.

STECK, Philippe. Droit et famille. Paris: Economica, 1997.

SUEL, Marc. Les prémière codifications à droit constant. Droits, Revue Française de Théorie, de Philosophie et de Culture Juridiques, Paris, n. 26, 1997.

TALLON, Deniz. La codification dans le système de common law. Droits, Revue Française de Théorie, de Philosophie et de Culture Juridiques, Paris, n. 27, 1998.

TELLES JUNIOR, Goffredo. A folha dobrada. Rio de Janeiro: Nova Fronteira, 1999.

TELLES JUNIOR, Goffredo. Direito quântico. 7. ed. São Paulo: Editora Juarez de Oliveira, 2003.

TELLES JUNIOR, Goffredo. Ética: do mundo da célula ao mundo dos valores. 2. ed. São Paulo: Editora Juarez de Oliveira, 2004. 
THÉRY, Irène. Les changements et leur perception de "la" famille aux "familles". Problèmes Politiques et Sociaux, França, n. 685, 1992.

TÔRRES, Heleno Taveira. Código Tributário Nacional: teoria da codificação, funções das leis complementares e posição hierárquica no sistema. Revista Dialética de Direito Tributário, São Paulo, n. 71, 2001.

VENÂNCIO, Renato Pinto. Maternidade roubada. In: VENÂNCIO, Renato Pinto (Coord.). História das mulheres no Brasil. São Paulo: Contexto, Unesp, 1997.

VERUCCI, Florisa (Org.). A difícil igualdade: os direitos da mulher como direitos humanos. Rio de Janeiro: Relume Dumará, 1994.

VILLAÇA AZEVEDO, Álvaro. Do concubinato ao casamento de fato. Belém: Cejup, 1987.

VILLAÇA AZEVEDO, Álvaro; TAVARES DA SILVA, Regina Beatriz Papa dos Santos. Sugestões ao Projeto de Código Civil - Direito de Família. Revista dos Tribunais, n. 730, 1996, p. 11.

VILLELA, João Baptista. O reconhecimento da paternidade entre o pós-moderno e o arcaico: primeiras observações sobre a Lei 8.560/1992. Repertório IOB de Jurisprudência, São Paulo, n. 4, fev. 1993.

VILLELA, João Baptista. Repensando o direito de família. In: CONGRESSO BRASILEIRO DE DIREITO DE FAMÍLIA, Anais... Belo Horizonte: Del Rey, 1999. 